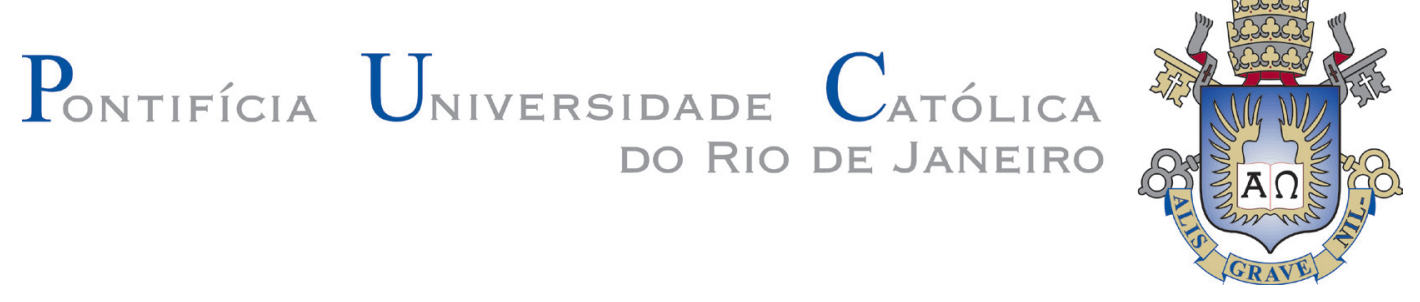

Bruno Wagner D’Almeida de Souza Santana

Da Grande Saúde em Nietzsche

Dissertação de Mestrado

Dissertação apresentada como requisito parcial para obtenção do grau de Mestre pelo Programa de Pós-graduação em Filosofia do Departamento de Filosofia da PUC-Rio.

Orientadora: Profa. Kátia Muricy 


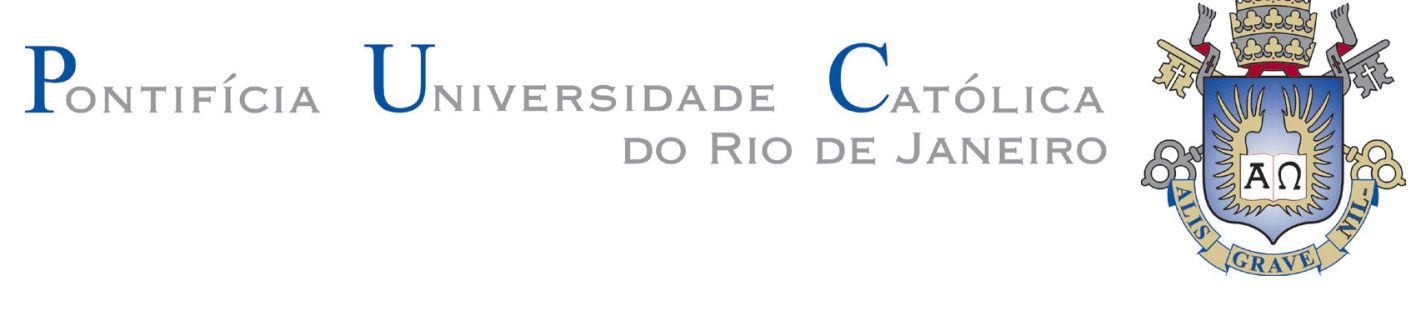

Bruno Wagner D’Almeida de Souza Santana

\section{Da Grande Saúde em Nietzsche}

Dissertação apresentada como requisito parcial para obtenção do grau de Mestre pelo Programa de Pós-graduação em Filosofia do Departamento de Filosofia da PUC-Rio. Aprovada pela Comissão Examinadora abaixo assinada.

Profa. Kátia Rodrigues Muricy

Orientadora

Departamento de Filosofia - PUC-Rio

Profa. Silvia Pimenta Velloso Rocha

Faculdade de Educação da Baixada Flumimense - UERJ

Prof. Miguel Angel de Barrenechea

Universidade Federal do Estado do Rio de Janeiro - UNIRIO

Profa. Denise Barruezo Portinari

Coordenadora Setorial do Centro de Teologia e Ciências Humanas - PUC-Rio

Rio de Janeiro, 28 de fevereiro de 2013 
Todos os direitos reservados. É proibida a reprodução total ou parcial do trabalho sem a autorização da universidade, da autora e do orientador.

\section{Bruno Wagner D'Almeida de Souza Santana}

Graduou-se em Psicologia pela UFJF (Universidade Federal de Juiz de Fora) em 2007, e em Filosofia pelo CES-JF (Centro de Ensino Superior de Juiz de Fora) em 2008. Pós-graduou-se na Especialização em Arte e Filosofia pela PUC-RJ (Pontifícia Universidade Católica do Rio de Janeiro) em 2011.

Ficha Catalográfica

Santana, Bruno Wagner D’Almeida de Souza

Da grande saúde em Nietzsche / Bruno Wagner D'Almeida de Souza Santana ; orientadora: Kátia Muricy. - 2013.

82 f. ; $30 \mathrm{~cm}$

Dissertação (mestrado)-Pontifícia Universidade Católica do Rio de Janeiro, Departamento de Filosofia, 2013.

Inclui bibliografia

1. Filosofia - Teses. 2. Grande saúde.

3. Doença. 4. Música. I. Muricy, Kátia. II. Pontifícia Universidade Católica do Rio de Janeiro. Departamento de Filosofia. III. Título.

CDD:100 
Aos amigos, parentes e à descontinuidade. 


\section{Agradecimentos}

À professora e orientadora Kátia Muricy pelo estímulo e parceria na realização deste trabalho.

Aos professores Miguel Barrenechea e Silvia Pimenta Velloso pela colaboração com minha pesquisa desde antes do meu ingresso no Mestrado e pela participação em minha banca de defesa. Quero também agradecer ao professor Caio Moura e às contribuições da professora Denise Maurano.

À Capes e à PUC-Rio, pelos auxílios concedidos, sem os quais este trabalho não poderia ter sido realizado.

Aos amigos, em especial a Leandro Domith, que foi de quem primeiro eu ouvi falar sobre a "grande saúde" em Nietzsche, me despertando a atenção para esse tema. Queria agradecer também a Aline Paiva pelos diálogos sobre o tema e a grande ajuda na formatação deste trabalho. Não poderia também deixar de lembrar da presença de Murilo Cavalcante, Ana Paula Muniz, Bianca Vilhena, Immanuel Lima, Emerson Facão, André Bentes, Carla Tell, Thaís Klein, Ebert Gonçalves e Rômulo Zapponi. Aos amigos (as) que me circundaram e me deram força, meu mais sincero agradecimento.

Aos meus pais e à minha irmã pelo apoio e sensibilidade. 


\section{Resumo}

Santana, Bruno Wagner D’Almeida de Souza; Muricy, Kátia. Da grande saúde em Nietzsche. Rio de Janeiro, 2013. 82p. Dissertação de Mestrado - Departamento de Filosofia, Pontifícia Universidade Católica do Rio de Janeiro.

Este trabalho procura compreender não apenas como Nietzsche articula saúde e doença, mas como inclui a doença na saúde. Para tanto, parte da indicação feita por Nietzsche no prefácio ao segundo volume de Humano Demasiado Humano, em 1886, onde afirma que o mais forte ensinamento desta obra consiste numa doutrina da saúde. No primeiro capítulo é feita uma análise da relação entre a saúde e doença nos prefácios de 1886. No segundo capítulo o objetivo é tentar localizar de que modo Nietzsche via na música wagneriana o caso clínico mais revelador do que considerava ser a doença da modernidade. No terceiro capítulo vai-se à Platão afim de mostrar como tal filósofo pensou o problema da saúde a partir de uma relação de identidade, como saúde em si, enquanto que o problema que Nietzsche enfrenta é justamente o da impossiblidade de pensar a saúde a partir de uma relação de identidade. Nas considerações finais o problema consiste em tentar compreender a inter-relação entre a necessidade da busca pelo prazer e o choque desta com a dor para que se possa então conquistar uma saúde.

\section{Palavras-chave}

Grande saúde; doença; música. 


\section{Résumé}

Santana, Bruno Wagner D’Almeida de Souza; Muricy, Kátia (Conseiller). De la grande santé dans Nietzsche. Rio de Janeiro, 2013. 82p. Dissertation Departamento de Filosofia, Pontifícia Universidade Católica do Rio de Janeiro.

Cet ouvrage cherche à comprendre non seulement comment Nietzsche articule la santé et la maladie, mais comment il comprend la maladie dans la santé. Dans le premier chapitre s'effectue une analyse de la relation entre la santé et la maladie dans les préfaces de 1886. Dans le deuxième chapitre l'objectif est d'essayer de trouver comment Nietzsche voyait dans la musique wagnérienne le cas clinique le plus révélateur de ce qu'il considérait être la maladie de la modérnité. Le troisième chapitre se réfère à Platon afin de montrer comment ce philosophe a pensé le problème de la santé à partir d'une relation d'identité, comme une santé en soi, pendant que le problème que Nietzsche affronte est précisément l'impossibilité de penser la santé dans une relation d'identité. Dans les considérations finales le problème est d'essayer comprendre l'interdépendance entre la nécessité de la recherche pour le plaisir et le choc de cette recherche contre la douleur afin qu'on puisse donc conquérir une santé.

\section{Mots-clés}

Grande santé; maladie; musique. 


\section{Sumário}

$\begin{array}{lr}\text { Introdução } & 9\end{array}$

$\begin{array}{ll}\text { Os prefácios de } 1886 & 17\end{array}$

capítulo segundo:

Grandeza, música, saúde e direção:

uma crítica à intuição intelectual por Nietzsche 26

capítulo terceiro:

Música, o problema da saúde e da unidade

capítulo quarto:

Da vontade de prazer 66

$\begin{array}{ll}\text { Conclusão } & 76\end{array}$

$\begin{array}{lr}\text { Referências Bibliográficas } & 80\end{array}$ 


\section{Introdução}

Em diversos momentos Nietzsche apresenta o tema da grande saúde correlacionando-o a um sentimento de excesso, de plenitude, de uma potência em transbordamento. À guisa de exemplo, podemos assim ver nas seguintes passagens: "Desse isolamento doentio, do deserto desses anos de experimento, é ainda longo o caminho até a enorme e transbordante certeza e saúde, que não pode dispensar a própria doença como meio e anzol para o conhecimento, (...) até a amplidão e refinamento interior que vem da abundância, (...) até o excesso de forças plásticas (...) que é precisamente a marca da grande saúde" ; no §382 da Gaia Ciência, Nietzsche se refere à grande saúde como um estado de "transbordante abundância e potência" em que o espírito se torna capaz de brincar com um mundo "pleno de perigos"; num fragmento póstumo de 1885, Nietzsche se refere a "essa enorme saúde que não busca nem mesmo evitar a doença, esse excesso mesmo de forças plásticas"3.

A questão está em que, se o mundo, se a vida (da qual o homem participa) acontece para Nietzsche como por um processo infindo de esbanjamento de forças, como entender essa relação saúde/doença, força/fraqueza, essa duplicidade a que Nietzsche se refere ao falar da grande saúde? Como a doença pode emergir num mundo que é pleno? Que relevância haveria em se pensar a doença dentro de um mundo que é concebido como plenitude? Por que ir à doença para pensar a saúde? Não seria essa uma visão cansada, pessimista, típica de homens impotentes? Como o sentimento de plenitude pode se articular a termos tais como fraqueza, sombra, dor, doença? Em 1888, Nietzsche afirma a esse respeito em Ecce homo: "A perfeita luz e alegria, mesmo exuberância do espírito, (...) harmoniza-se em mim não só com a mais profunda fraqueza fisiológica, mas até mesmo com um excesso da sensação de dor."

Como entender que essa "enorme saúde (...) não procura evitar [nem] mesmo a doença" " ? De que modo tais estados encontram-se ligados por uma transbordante

\footnotetext{
NIETZSCHE, F., Humano, demasiado humano, prólogo, §4, p. 10.

NIETZSCHE, F.,Gaia ciência, §382, p. 286.

NIETZSCHE, F., Fragments posthumes, v. XI, août-septembre de 1885, 40 [66], p. 403.

4 NIETZSCHE, F., Ecce homo, §1, p. 21.

5 NIETZSCHE, F., Fragments Posthumes, v. XI, août-septembre de 1885, 40 [66], p. 403.
} 
abundância e potência ${ }^{6}$ ? Como compreender a articulação que Nietzsche propõe entre saúde e doença a partir do que nomeou por grande saúde? Nesta, como excesso, transbordamento de forças, pode equivaler a perigo, de modo a que plenitude e dor não se tornem termos excludentes? Como plenitude e ocaso, excesso e finitude ${ }^{7}$ podem conjugar-se? Eis o objetivo de nossa proposta de pesquisa, um estudo aprofundado que, sob o enfoque de tais questões, consiste em apreender o que Nietzsche entendeu por plenitude a partir da grande saúde, de maneira que retomamos um problema já posto por Nietzsche em agosto de 1886 - há talvez um sofrimento devido à própria superabundância ${ }^{8}$ — e tentamos pensá-lo com a ajuda de um tema que lhe foi muito caro, embora ainda pouco explorado, o tema da grande saúde.

Como suportar um mundo que já não porta consigo nenhum sentido a priori? Diante da ausência de sentidos absolutos, Nietzsche irá traçar uma relação entre superabundância, dor, saúde e trágico, problematizando dessa maneira a relação costumeira feita entre dor e carência e sugerindo a ideia de que o sofrimento em alguns casos - em especial no caso dos gregos - pode advir não de uma fraqueza, porém de um alto grau de sensibilidade que por sua vez decorre de uma plenitude, de uma superabundância que faz do homem saudável, forte, nobre, um homem também mais exposto a situações de risco e ocasos diversos, a desorganizações, perdas, desgastes e perigos.

\begin{abstract}
O mais rico em plenitude de vida, o deus e o homem dionisíaco, pode permitir-se não só a visão do terrível e discutível, mas mesmo o ato terrível e todo luxo de destruição, decomposição, negação; nele o mau, sem sentido e feio parece como que permitido em virtude de um excedente de forças geradoras, fertilizadoras, capaz de transformar todo deserto em exuberante pomar. ${ }^{9}$
\end{abstract}

E de que modo o trágico faz aparição nessa correlação que faz Nietzsche? De modo a que a dor não constitua para o homem forte nenhum motivo de desencantamento perante a vida, nem mesmo justificativa para que se ergam cultos e hinos de glória à dor e ao sofrimento ${ }^{10}$; não, não se trata disso, mas de nos tornarmos capazes de viver com alegria os riscos que a vida traz consigo sem que para isso tenhamos que extirpar o antagonismo presente em tudo que vive e cresce, assim como também perece e se fortifica - ainda que isso muitas vezes nos acarrete feridas e experiências nem sempre tão agradáveis, efeitos de uma guerra ${ }^{11}$ — os perigos da libertação

\footnotetext{
$6 \quad$ NIETZSCHE, F., Gaia ciência. §382, p. 286.

7 NIETZSCHE, F., Assim falava Zaratustra, prólogo, §1, p. 33; Dos três males, §1, p. 224.

8 NIETZSCHE, F., O nascimento da tragédia, Tentativa de autocrítica, $\$ 1$, p. 14.

9 NIETZSCHE, F., Gaia ciência, §370, p. 273.

10 NIETZSCHE, F., Além do bem e do mal, §293, p. 176.

11 NIETZSCHE, F., Crepúsculo dos ídolos, p. 07.
} 
do espírito está em que quando um homem busca a liberação do espírito, também os seus desejos e paixões esperam secretamente obter vantagem disso ${ }^{12}$. "Já não admiramos os dentistas que extraem os dentes para que eles não doam mais..." ${ }^{13}$ É somente ao preço de um enfrentamento que nos tornamos dignos de uma vida grande ${ }^{14}$.

Essa inter-relação entre superabundância, dor, saúde e trágico fica explícita na "Tentativa de Autocrítica":

Uma questão fundamental é a relação dos gregos com a dor, seu grau de sensibilidade (...), aquela questão de se realmente o seu cada vez mais forte anseio de beleza, (...) brotou da carência, da privação, da melancolia, da dor. ${ }^{15}$

Será o pessimismo necessariamente o signo do declínio, da ruína, do fracasso, dos instintos cansados e debilitados (...)? Há um pessimismo da fortitude ? Uma propensão intelectual para o duro, o horrendo, o mal, o problemático da existência, devido ao bem-estar, a uma transbordante saúde, a uma plenitude da existência? Há talvez um sofrimento devido à própria superabundância? (...) O que significa, justamente entre os gregos da melhor época, da mais forte, da mais valorosa, o mito trágico? ${ }^{16}$

- Num fragmento póstumo de 1887, Nietzsche afirma que, diante do enigma da existência, diante de uma natureza que é indiferente ao homem, e que por isso mesmo é grande e bela, os espíritos heróicos são aqueles capazes, por um excesso de força, de se auto-afirmarem na crueldade trágica, duros o bastante para experimentar o sofrimento como um prazer, com alegria ${ }^{17}$. O herói trágico acena assim necessariamente para uma tensão e para a auto-afirmação de si nessa tensão, pois é justamente aquele que se glorifica em luta, e não há luta - caráter fundamental da vida - sem que haja tensão; o herói trágico é aquele que é capaz de suportar como um prazer superior as mais dolorosas superações, as mais torturantes contradições e sofrimentos presentes em seu trajeto. ${ }^{18}$

Mas que tensão é essa, que elementos a compõem? Desprazer e prazer, força e fraqueza, saúde e doença, plenitude e privação? Uma vez que a vida é demasiado intensa, exuberante, excessiva, violenta, caracterizada fundamentalmente por ser atividade $^{19}$, como poderíamos fixar valores? Onde encontrar repouso e estabilidade em meio a esse turbilhão? Muitos provavelmente se levantariam nessa hora para

12 NIETZSCHE, F., Humano, demasiado humano. §542, p. 246.

13 Ibid. V, §3, p. 35.

14 NIETZSCHE, F., Crepúsculo dos ídolos. V, §1, p.33.

15 NIETZSCHE, F., O nascimento da tragédia, Tentativa de autocrítica, §4, p. 17.

16 NIETZSCHE, F., O nascimento da tragédia, Tentativa de autocrítica, §1, p. 14.

17 NIETZSCHE, F., Fragments Posthumes, v. XIII, automne 1887, 10 [168], p. 190.

18 NIETZSCHE, F., O nascimento da tragédia. §24, p. 141.

19 NIETZSCHE, F., Genealogia da moral, II, §12, p. 167. 
dizer que Nietzsche é a favor do devir, que, para Nietzsche, bem viver é imiscuir-se no instante e deixar o fluxo da vida nos levar. - Ledo engano. Se Nietzsche por um lado foi inteiramente crítico às concepções racionalistas que buscaram congelar o movimento da vida, sabia ele por outro lado que o homem por si próprio é incapaz de abarcar a vida no seu todo, em toda sua potência; o homem é uma ínfima parte surgida ao acaso na natureza, devendo assim lutar se não quiser ver sua existência ser completamente aniquilada pelas forças da vida, da natureza, do mundo, dos homens.

Esse é um problema que percorre toda a obra de Nietzsche, podendo ser visto inicialmente desde $O$ Nascimento da Tragédia, por exemplo, em que a dimensão apolínea - caracterizada por formas bem delineadas, harmônicas, equilibradas- está sempre se chocando com a dimensão dionisíaca - caracterizada pela embriaguez, dissolução, indistinção e deformação dos contornos; e o que é mais importante, se por um lado o apolíneo não pode se abster de confrontar-se com o dionisíaco, este por sua vez não pode ser vivido em estado puro, bruto, pois isso acarretaria a completa aniquilação e estiolamento de toda e qualquer singularidade - que para continuar existindo não pode prescindir em absoluto da manutenção de um mínimo de unidade que seja.

Na Segunda consideração extemporânea, por exemplo, esse mesmo problema irá se apresentar do seguinte modo: Nietzsche irá traçar uma distinção entre história e vida, para em seguida tomar parte desta como critério de avaliação da história, o que fica claro já no próprio subtítulo da obra: Da utilidade e dos inconvenientes da história para a vida. O problema é: como pôr-se a par da vida? Se por um lado Nietzsche detecta no homem moderno a "doença da história" ${ }^{20}$, doença que pretende calcular a vida arrogando-se para isso um saber intelectual sobre ela, como se a vida pudesse ser determinada e explicada causalmente em todas as suas dimensões pela ciência da história, por outro lado Nietzsche afirma que o homem, ao contrário do animal, não pode viver de maneira inteiramente não histórica: "Represente, para tomarmos um exemplo extremo, um homem que não possuísse a força de esquecer e fosse condenado a ver em toda coisa um devir: um tal homem não acreditaria sequer em sua própria existência, não acreditaria mais em si, ele veria tudo se dissolver numa multiplicidade de pontos moventes e perderia o chão nessa torrente do devir: um verdadeiro discípulo de Heráclito, ele terminaria por não ousar levantar sequer um dedo. Toda ação exige o esquecimento, assim como toda vida orgânica exige não somente a luz, mas também a escuridão". ${ }^{21}$ Determinar o grau em que o passado deverá ser esquecido ou não, isso é algo relativo ao quantum de forças plásticas possui cada indivíduo, povo ou nação; em suma, o que irá determinar essa medida é um problema que em última instância diz respeito ao que

\footnotetext{
20 NIETZSCHE, F., Ecce homo, As extemporâneas, §1, p. 64,
}

$21 \quad$ NIETZSCHE, F., Considérations inactuelles II. §1, p. 97. 
Nietzsche entende por saúde: "o elemento histórico e o elemento não histórico são igualmente necessários à saúde de um indivíduo, de um povo, de uma cultura". ${ }^{22}$

Como uma crítica ao historicismo que vinha se desenvolvendo na Alemanha, Nietzsche se pôs a escrever em 1873 sua Segunda Consideração Extemporânea. Nela Nietzsche aponta o fato de que a ruína ${ }^{23}$ de uma cultura não é decorrência necessária do que se valora ${ }^{24}$ como um vício, mas pode aparecer justamente como decorrência da hipertrofia de algo que até então tenha sido considerado uma virtude, tal como a "história" na Alemanha do século XIX. Diante da fratura em que se situa o homem - entre o histórico e o não-histórico, entre o instante e a memória, entre a vida que escorre e o pensamento que busca organizá-la - o que Nietzsche percebe é que o homem moderno superinveste um excesso de história tentando com isso conservar-se, proteger-se do vir-a-ser que caracteriza a vida, controlá-la; no entanto, o que decorreu disso foi o enfraquecimento do homem moderno, pois desaprendeu a positividade do esquecimento ao desvincular história e vida. Querer viver o puro histórico é desvincular-se da própria vida enquanto momento presente que acontece, é superinvestir uma regressão ad infinitum das causas, é se perder na multiplicidade de pontos moventes do passado. Mas por outro lado, o problema está em que não se pode viver o puro devir, o puro presente, o não-histórico puro, o que corresponderia a uma completa desintegração de si no caos.

Uma questão problematizando o agir, questionando e requerendo uma medida para o agir, para a ação. Poderíamos ser levados a pensar que Nietzsche aponta o que seria uma ética do equilíbrio, do "caminho do meio" entre a história e a vida... Mas não é isso que ele afirma na Primeira consideração extemporânea:

Seria um erro ver uma virtude aristotélica nessa moderação prudente, senão sábia, e nessa 'mediocritas' da coragem: pois essa coragem não é o meio entre dois erros, mas entre uma virtude e um defeito - e é nesse meio entre uma virtude e um defeito que se enraízam todas as características do filisteu..$^{25}$

(...) o meio entre dois vícios não é sempre a virtude, mas bem frequentemente fraqueza, paralisia, impotência. (...) Uma secura e sobriedade extremas, uma sobriedade verdadeiramente famélica, induzem atualmente na massa cultivada o sentimento artificial de serem signos de saúde, (...) eles vêem saúde onde nós apenas vemos debilidade, morbidez e superexcitação onde nós reconhecemos a verdadeira saúde. ${ }^{26}$

22 Ibid. §1, p. 98.

23 NIETZSCHE, F., Considérations inactuelles II. p.94.

24 Lembro aqui que uma crítica das origens dos valores morais só irá aparecer com esses termos em 1978, com Humano, demasiado humano, para então ser desenvolvido com mais ênfase na Genealogia da moral (1887).

25 NIETZSCHE, F., Considérations inactuelles $I$, $\$ 8$.

26 NIETZSCHE, F., Considérations inactuelles I, §11. 
Em A filosofia na era trágica dos gregos Nietzsche retorna aos gregos para, por trás dos principais problemas que motivaram a origem do pensamento filosófico - a multiplicidade, o movimento e a infinitude ${ }^{27}$ - detectar o que há de mais pessoal em cada sistema de pensamento, assim como para "trazer à luz aquilo que devemos sempre amar e ter em altíssima conta, e aquilo que nenhum conhecimento poderá nos roubar: o grande homem. ${ }^{28}$ Mas o que queria ele dizer com grande homem?

O juízo de tais filósofos acerca da vida e da existência é incomparavelmente mais pleno de sentido do que um juízo moderno devido ao fato de que eles tinham a vida diante de si numa prodigiosa perfeição e porque, à diferença de nós, neles o sentimento do pensador não se perde no antagonismo próprio ao desejo por liberdade, beleza, grandeza de vida e impulso à verdade, e apenas indaga: de que vale em geral, a vida? ${ }^{29}$

Foi quando os homens se viram sob os enormes perigos e seduções da laicização, sob a ameaça da derrocada do sentido e fundamento último que os mantinha "firmes" em meio ao vir-a-ser, foi nesse momento em que a tragédia veio à baila no mundo grego e onde pôde surgir a pergunta pelo valor da existência ${ }^{30}$. Foi justo nesse momento - em que os gregos se depararam com "o cru, o disforme, o vazio e o feio"31 - em que eles puderam dar mostras de sua grandeza ${ }^{32}$ e saúde ${ }^{33}$ ao amansar seu impulso de conhecimento, buscando aprender em prol da vida, e não da erudição:

(...) o desenfreado impulso ao conhecimento barbariza tanto quanto o ódio ao conhecimento, e (...) por meio de uma necessidade ideal de vida, os gregos domaram seu intrinsecamente insatisfeito impulso ao conhecimento - porque desejavam viver, de imediato, aquilo que aprendiam. ${ }^{34}$

A discussão de Nietzsche sobre a grande saúde se insurge em um momento de crise, momento em que os valores não se sustentam mais substancialmente, em que a potência do conhecimento intelectual se encontra desacreditada, em que

jamais nos será dado, mediante palavras e conceitos, colocar-se atrás do muro das relações, como que em algum fabuloso fundamento primordial das coisas (...). É absolutamente impossível ao sujeito ver algo para além de si e querer conhecê-lo, tão impossível que conhecer e ser constituem as mais contraditórias de todas as esferas. ${ }^{35}$

\footnotetext{
27 NIETZSCHE, F., A filosofia na era trágica dos gregos, p. 101.

28 Ibid. p. 28.

29 Ibid. p. 37.

30 Ibid. p. 37.

31 Ibid. p. 34.

32 Ibid. p. 48.

33 Ibid. p. 32.

34 Ibid. p. 34.

35 Ibid. p.88.
} 
Momento de um "grande perigo", um "grande acontecimento", em que se faz preciso conquistar uma "grande saúde". O grande perigo para Nietzsche não é o pessimismo, mas uma certa dimensão de "absurdo" da qual todo acontecimento participa, ou seja, o fato de que o mundo não tem nenhum sentido ${ }^{36}$.

O que quer que tenha valor no mundo de hoje não o tem em si, conforme sua natureza - a natureza é sempre isenta de valor: - foi-lhe dado, oferecido um valor, e fomos nós esses doadores e ofertadores! O mundo que tem algum interesse para o ser humano, fomos nós que o criamos! $!^{37}$

No terceiro parágrafo da Genealogia da moral, criticando o ideal ascético que, sofrendo da própria falta de sentido do sofrer $^{38}$, busca fiar-se numa espécie de faitalisme $^{39}$ (e com isso acaba por fazer desta vida uma ponte para uma outra vida, uma vida "melhor"), Nietzsche remete explicitamente o leitor a ir ao encontro do livro V da Gaia ciência. Este livro se inicia anunciando um "grande acontecimento" e termina fazendo uma exaltação à "grande saúde". Com grande acontecimento Nietzsche está se referindo à morte de Deus e chamando a atenção para fato de que é preciso tomarmos esse grande acontecimento não como algo triste e sombrio, mas que vejamos na aniquilação e queda dos valores absolutos "uma nova espécie de luz, de felicidade, alívio, contentamento, encorajamento, aurora..." ${ }^{" 40}$ Como poderíamos ver luz, aurora, como quer Nietzsche, num mundo que é caos, "não num sentido de necessidade, mas de ausência de ordem, divisão, forma, beleza, sabedoria" 41 ? Por que a conquista de uma grande saúde, "uma tal que não apenas se tem, mas constantemente se adquire e é preciso adquirir, pois sempre de novo se abandona e é preciso abandonar" ${ }^{\prime 2}$ não seria também um permanente grande desafio? Que problemas ele coloca? Que dificuldades traz consigo?

Positivar um mundo "pleno de perigos", caos, barbárie, talvez seja a conquista do limite mais tênue, forte e frágil de si.

Não estaria Nietzsche propondo com saúde uma positivação de um certo desequilíbrio?:

Isto deveria valer para todos os mortais mais bem logrados de corpo e espírito, que estão longe de colocar seu frágil equilíbrio de "animal e anjo" entre os argumentos

36 NIETZSCHE, F., Fragments posthumes, v. XI, août-septembre 1885, 39 [15], p. 360.

37 NIETZSCHE, F., Gaia ciência, §301, p. 204.

38 NIETZSCHE, F., Genealogia da moral, III, §28, p. 149.

39 Ibid. III , §24, p. 139.

40 NIETZSCHE, F., Gaia ciência, §343, p. 234.

41 Ibid. §109, p. 136.

42 Ibid. §382, p. 286. 
contra a existência - os mais finos e lúcidos, como Goethe, como Hafiz, enxergaram nisso até mesmo um estímulo mais para viver ${ }^{43}$;

De uma certa doença?:

Qual seria a origem dessa condição doentia? Pois o homem é mais doente, inseguro, inconstante, indeterminado, que qualquer outro animal, não há dúvida (...) como não seria um tão rico e corajoso animal também o mais exposto ao perigo, o mais longa e profundamente enfermo entre todos os animais enfermos? ${ }^{44}$;

De uma certa falta de sentido?:

O sacerdote ascético não hesitou em tomar a seu serviço toda a matilha de cães selvagens que existem no homem (...) sempre com o mesmo objetivo, despertar o homem de sua longa tristeza, pôr em fuga ao menos por instantes a sua surda dor, sua vacilante miséria, e sempre sob a coberta de uma interpretação e "justificação" religiosa. Todo excesso de sentimento dessa natureza tem o seu preço, (...) ele torna o doente mais doente." ${ }^{45}$

A falta de sentido do sofrer, não o sofrer, era a maldição que até então se estendia sobre a humanidade - e o ideal ascético lhe ofereceu um sentido! ${ }^{46}$;

Ou mesmo de uma certa impotência?:

A cisão de um protoplasma em 2 intervém quando a potência não mais é suficiente para dominar as posses adquiridas: a geração é consequência de uma impotência. Lá onde os machos procuram as fêmeas e nelas se propagam, a geração é conseqüência de uma fome ${ }^{47}$ ?

\section{Mas quem é forte o bastante para isso? ${ }^{48}$}

A atual pesquisa tem por base a afirmação de Nietzsche que diz que fora durante seus anos de menor vitalidade, período de $O$ andarilho e sua sombra ${ }^{49}$, que ele deixara de ser pessimista ${ }^{50}$, que o mais forte ensinamento de Humano demasiado humano consiste numa doutrina da saúde ${ }^{51}$. Atento a essas indicações de Nietzsche, o presente trabalho se desenvolveu sobretudo a partir de uma investigação da obra Humano demasiado humano.

43 NIETZSCHE, F., Genealogia da moral, III, §2, p. 88.

44 Ibid. III, §13, p. 110.

45 Ibid. III, §20, p. 128.

46 Ibid. III, §28, p. 149.

47 NIETZSCHE, F., Fragments Posthumes, v. XII, automne 1885- printemps 1886, 1[118], p. 48.

48 NIETZSCHE, F., Genealogia da moral, II, 24, p. 84.

49 NIETZSCHE, F., Ecce homo, "Por que sou tão sábio", §1, p. 21.

50 Ibid. §2, p. 23.

51 NIETZSCHE, F., Humano, demasiado humano II, prefácio , §2, p. 09. 


\section{Os prefácios de 1886}

Em 1886, Nietzsche prefaciou Gaia ciência, O nascimento da tragédia, Aurora, Humano demasiado humano I e II; em todos estes prefácios o jogo saúde/doença constitui uma questão central. De que modo Nietzsche aí se utiliza dos termos saúde e doença? Que relevância tais termos ocupam nesses prefácios?

Eu espero ainda que um "médico" filosófico, no sentido excepcional do termo alguém que persiga o problema geral de um povo, de uma época, de uma raça, da humanidade - tenha futuramente a coragem de levar ao cúmulo minha suspeita e de arriscar a seguinte afirmação: em todo o filosofar, até o momento, a questão não foi absolutamente a "verdade", mas algo diferente, como saúde, futuro, poder, crescimento, vida... ${ }^{52}$

A saúde emerge aqui como contraponto à "verdade". Perseguindo a todo custo a verdade, a filosofia estaria em realidade perseguindo a saúde sem perceber que, no entanto, saúde e "verdade" são coisas distintas. Saúde diz respeito a crescimento, poder, vida, futuro. Nietzsche aí levanta uma suspeita e arrisca então o que seria uma constatação: a filosofia se equivoca ao crer que persegue a verdade. De onde poderia ter partido essa suspeita?

Mas os juízos de valor "lógicos" não são os mais profundos e mais fundamentais a que pode descer a ousadia de nossa suspeita: a confiança na razão, com que se sustenta ou cai a validez desses juízos, é, sendo confiança, um fenômeno "moral"...53

A suspeita de Nietzsche em relação à verdade é uma desconfiança em relação ao poder da razão diante da vida. Entre a vida e a razão não há continuidade, uma identidade entre as duas, mas uma ruptura, uma descontinuidade; a tentativa de suprimir essa descontinuidade e crer que a razão pode deter as rédeas da vida, que o mundo é uma extensão da razão, tal crença é um fenômeno moral, uma pretensão moral que quer falar em nome da própria vida, como se moral e vida fossem a mesma coisa, como se houvesse um liame essencial, uma continuidade e mesmo identidade entre moral e vida. Mas a vida não é excogitação da moral ${ }^{54}$, e pretender isso foi a presunção dos filósofos de até agora.

52 NIETZSCHE, F., Gaia ciência, prefácio, §2, p. 12.

53 NIETZSCHE, F., Aurora, prefácio, §4, p. 13.

54 NIETZSCHE, F., Humano, demasiado humano, prefácio,§1, p. 08. 
Nos prefácios de 1886, dois motivos parecem impulsionar a suspeita de Nietzsche em relação à moral: um exame da razão diante dela mesma (malgrado Nietzsche afirmar que tal exame é impossível) e mais fundamentalmente um exame da razão diante da dor:

\begin{abstract}
A que se deve que, a partir de Platão, todos os arquitetos da Europa tenham construído em vão? Que tudo o que eles próprios tinham séria e honestamente por 'aere perennis' [mais duradouro que o bronze] ameace desabar ou já se encontre em ruínas? Ah, como é falsa a resposta que ainda hoje se tem para essa pergunta, "porque todos eles negligenciaram o pressuposto, um exame do fundamento, uma crítica da razão inteira" - a fatídica resposta de Kant, que verdadeiramente não nos atraiu, a nós, filósofos modernos, para um terreno mais sólido e traiçoeiro! (-e, perguntando agora, não era algo estranho exigir que um instrumento criticasse a sua própria adequação e competência? Que o próprio intelecto "conhecesse" seu valor, sua força, seus limites?Não era isso até mesmo um absurdo? A resposta correta seria, isto sim, que todos os filósofos construíram sob a sedução da moral, inclusive Kant — que aparentemente seu propósito dirigia-se à certeza, à "verdade", mas, na realidade, a “"majestosos edifícios morais"” (...). Por outro lado, (...) "não teria necessitado dela, se para ele uma coisa não fosse mais importante que tudo, tornar o "mundo moral" inatacável ou, melhor ainda, inapreensível pela razão..$^{55}$
\end{abstract}

Kant demonstrou na Crítica da razão pura a impossibilidade de a razão apreender a coisa-em-si, mas isso que se mostrou não possível na primeira Crítica, Kant mostrou ser possível na segunda Crítica, no nível da moral, de uma razão prática. Para Nietzsche, com isso Kant teria dado a ver não apenas que a razão é demasiado suspeita quando pretende enxergar e mostrar seus próprios limites, seus desvios, seus subterfúgios, e colocar a si própria em xeque, mas demonstrou também que a razão é racionalmente incapaz de alçar uma certeza plena, não há uma certeza racional absoluta sobre o mundo, sobre a vida, mas uma "certeza" moral; a razão por ela própria não consegue encontrar um fundamento sólido e firme o bastante que a possibilite erradicar por completo a dúvida, a incerteza. Mas, isso é importante no argumento de Nietzsche, ao postular que a apreensão da coisa-em-si seria realizável no campo da razão prática, Kant teria sido uma espécie de anunciador de que a perseguição da verdade é antes uma investigação de ordem moral - e não de ordem racional como quiseram os filósofos de até então.

É próximo do cômico ver nossos filósofos exigir que a filosofia comece necessariamente por uma crítica da faculdade de conhecer: não é inverossímil que o órgão do conhecimento possa se "criticar" ele mesmo, quando nós nos tornamos desconfiados quanto aos resultados anteriores do conhecimento? A 'redução da filosofia à "vontade de uma teoria do conhecimento" é cômica. Como se pudéssemos assim encontrar uma "certeza"!

55 NIETZSCHE, F., Aurora, prefácio, §3, p. 11.

56 NIETZSCHE, F., Fragments Posthumes, v. XII, automne 1885-printemps 1886, 1[60], p. 35. 
O órgão do conhecimento, a razão, não poderia criticar-se senão para recolocar-se a si próprio, isto é, para se tornar mais racional que até então, assentado em fundamentos mais sólidos, de modo que uma suspeita radical com relação à confiança na razão não poderia advir da própria razão, mas unicamente a partir de algo externo a ela. Para tomar a moral como problema ${ }^{57}$ é preciso estar fora dela, do mesmo modo que Nietzsche afirma que o problema da ciência não pode ser reconhecido no terreno da própria ciência. ${ }^{58} \mathrm{E}$ o que permite a Nietzsche, nesses prefácios, situar-se num ângulo externo à moral é uma grande dor. É a grande dor que permite que Nietzsche se situe fora da moral e assim possa desconfiar dela. Tal desconfiança se dá pela suspeita de que a moral busca conservar-se, buscar repou$\mathrm{so}^{59}$, mas nessa medida, na medida em que ela busca garantias, certezas ${ }^{60}$, ela se revela uma vontade de negação da vida ${ }^{61}$ — pois vida não é conservação de si, mas vir a ser: "não existem fatos eternos: assim como não existem verdades absolutas"62.

O fundamento que os filósofos de até então renovadamente buscaram, um após o outro, e acreditaram alcançar mediante um hiperdesenvolvimento cada vez maior da razão, é um artifício, uma sedução moral que encanta, que entusiasma quando oferta a máxima segurança e estabilidade face à inconstância e aos riscos que o vir a ser exige de tudo o que vive. Mas a moral, (...) sua segurança repousa mais ainda em certa arte do encanto ${ }^{63}$.

Se a dor e a doença servem como perspectivas para que Nietzsche critique a moral, isso se dá na medida em que nela, ao contrário do que a moral sempre quis, não se quer conservar, e todos os valores que até então supunham-se perenes, eternos, absolutos, garantia de estabilidade, na doença e na dor encontram-se em ruínas, em falência, sob suspeita:

E no que toca à doença: não estaríamos quase tentados a perguntar se ela é realmente dispensável para nós? Apenas a grande dor é o extremo liberador do espírito, enquanto mestre da "grande suspeita" (...). Apenas a grande dor, a lenta e prolongada dor, aquela que não tem pressa, na qual somos queimados com madeira verde, por assim dizer, obriga a nós, filósofos, a alcançar nossa profundidade extrema e nos desvencilhar de toda confiança, toda benevolência, tudo o que encobre, que é brando, mediano, tudo em que antes púnhamos nossa humanidade. Duvido que uma tal dor "aperfeiçoe" —; mas sei que nos 'aprofunda'. ${ }^{64}$

57 NIETZSCHE, F., Aurora. prefácio §3, p. 10.

58 NIETZSCHE, F., O nascimento da tragédia, prefácio §2, p. 15.

59 NIETZSCHE, F., O nascimento da tragédia. prefácio §5, p. 19.

60 NIETZSCHE, F., Aurora. prefácio, §3, p. 10.

61 NIETZSCHE, F., O nascimento da tragédia, prefácio,§5, p. 19.

62 NIETZSCHE, F., Humano, demasiado humano, §2, p. 16.

63 NIETZSCHE, F., Aurora, prefácio $\$ 3$, p. 10.

64 NIETZSCHE, F., Gaia ciência, prefácio, §3, p. 13. 
O que fará então com que Nietzsche ponha a moral sob suspeita não é uma nova razão, uma razão "maior", mais alargada, mas uma "grande dor". Fazer uma crítica da moral a partir da razão seria recair no mesmo engodo da tradição que procurou criticar a razão com a razão, o conhecimento com o conhecimento, mas assim apenas reforçou um artifício moral. Procurando criticar a razão a partir da própria razão, os filósofos sempre recaíram num círculo moral: “melhor" utilizando-se da razão refundaram a moral em novas bases e continuadamente pretenderam sobrepor a razão à vida.

Uma crítica à moral é fundamental nos prefácios de 1886, pois é a partir dessa crítica que Nietzsche pode desenvolver dois temas centrais desses prefácios: uma grande liberação e um fortalecimento espiritual.

Solapar a confiança na moral é condição para que se possa autodeterminar os próprios valores. Os alicerces em que a moral se apoiava ruíram, a confiança depositada nas coisas cessou, a confiança na vida se foi, a vida mesma tornou-se um problema $^{65}$. Aonde podemos depositar nossa confiança quando tudo se desmancha em meio ao vir a ser? Em que acreditar? Em que podemos depositar nosso querer? A confiança na moral se foi, não mais acreditamos em substâncias eternas e atemporais, inteiramente estáveis, sempre constantes, imutáveis, imperecíveis, superiores à vida. Não se confia em mais nada ${ }^{66}$, tornamo-nos solitários. De toda profunda suspeita decorre um isolamento, calafrios e angústias do isolamento ${ }^{67}$; de toda profunda suspeita resulta uma enfermidade ${ }^{68}$, um estado de debilidade (solidão, exílio, acedia, inatividade $)^{69}$, estado que se consome e tem sua autoconservação posta em xeque.

Não creiam que eu venha exortá-los às mesmas audácias! Ou à mesma solidão! Pois quem perfaz esses caminhos próprios não encontra ninguém (...). Ninguém aparece para ajudá-lo; tem de lidar sozinho com tudo o que se lhe depara de perigo, de maldade e mau tempo. ${ }^{70}$

Nietzsche descreve o momento da grande liberação como um momento análogo a um tremor de terra, um abalo em que a alma é arrancada de si, um arrebatamento onde um impulso, uma vontade, um ímpeto, passa a ter domínio e governo sobre a jovem alma. A razão e o entendimento não gozam de privilégio algum nesse momento, mas encontram-se deslocados e sobrepujados por um anseio que vem

65 NIETZSCHE, F., Gaia ciência, prefácio §3, p. 13.

66 NIETZSCHE, F., Humano, demasiado humano II, prefácio §1, p. 08.

67 NIETZSCHE, F., Humano, demasiado humano, prefácio §1, p. 07.

68 NIETZSCHE, F., Gaia ciência, prefácio, §3, p. 12.

69 NIETZSCHE, F., Humano, demasiado humano, prefácio §2, p. 08.

70 NIETZSCHE, F., Aurora. prefácio §2, p. 09. 
não se sabe de onde. A jovem alma é sacudida (...) - ela própria não entende o que se passa $^{71}$. A grande liberação seria um momento de desprendimento do tipo espírito livre em relação à sua origem, ao solo de onde proveio, à mão que o guiara, ao santuário que até aqui adorara. A libertação desse "aqui” é um deixar para trás o que até agora fora sua "casa", uma suspeita em relação ao que até então amara. Como conseqüência do desprendimento dos laços mais fortes que o constituíram, do rompimento com o que fora considerado por ele seus mais altos valores, suas adorações e paixões, advém um tornar-se solitário, um caminhar em meio ao deserto que surge como decorrência do declínio dos valores aos quais ele estava até então referido. "A solidão o cerca e o abraça, sempre mais ameaçadora, asfixiante, opressiva, terrível deusa e mater saeva cupidinum [selvagem mãe das paixões]". ${ }^{72}$

Uma rebeldia, um gesto profanador que deixa para trás aquilo que justamente mais amara, um ódio ao amor, um desprendimento, uma ânsia de ir seja para onde for, uma ânsia por novos mundos inflama agora seus sentidos, como uma perigosa curiosidade, "um rebelde, arbitrário, vulcânico, anseio de viagem, de exílio, afastamento, esfriamento, enregelamento"73. Mas aos olhos de Nietzsche nesse tremor do espírito nem tudo é horror, desgoverno de si, mas combina-se a isso uma alegria, à tal embriaguez combina-se também uma sobriedade. "Há uma alegria nesse tremor, uma vitória — uma vitória? sobre o quê? sobre quem? Enigmática, plena de questões, questionável, mas a primeira vitória: - tais coisas ruins e penosas pertencem à história da grande liberação. Ela é simultaneamente uma doença que pode destruir o homem."74 Ao mesmo tempo em que a doença pode enfraquecer o homem a tal ponto de destruí-lo, pode ela também ser o pressuposto de uma liberação, de uma grande liberação.

Mas em que medida a dor seria o grande liberador do espírito? Isso se dá na medida em que a dor convoca uma solidão, um distanciamento da moral, isto é, dos valores tidos até então como 'naturais', inteiramente confiáveis. O doente é nesse sentido alguém 'imoral', alguém que oferece perigo à integridade da comunidade - como se pode ver, por exemplo, na experiência do Ocidente, em que os ditos doentes são muitas vezes confinados em hospitais e instituições asilares em geral - conquanto a moral busque conservar a comunidade. Estar doente é não gozar da estabilidade e dos pressupostos que a vida em sociedade requer, é portanto ocupar uma perspectiva deslocada, um ângulo de visão que excede a integridade da comunidade a que até então pertencera.

71 NIETZSCHE, F., Humano, demasiado humano, prefácio , §3, p. 09.

72 Ibid. $\S 3$, p. 10.

73 Ibid. $\$ 3$, p. 09.

74 Ibid. $\$ 3$, p. 10. 
Ser moral, morigerado, ético significa prestar obediência a uma lei ou tradição há muito estabelecida. (...) "Egoísta" e "altruísta" não é a oposição fundamental que levou os homens à diferenciação entre moral e imoral, bom e mau, mas sim estar ligado a uma tradição, uma lei, ou desligar-se dela. Nisso não importa saber como 'surgiu' a tradição, de todo modo ela o fez sem consideração pelo bem e o mal, ou por algum imperativo categórico imanente, mas antes de tudo a fim de conservar uma 'comunidade' (...)..$^{75}$

Se a moral quer conservar, tornar estável, para isso fixando valores transcendentes à vida, a grande dor é o que permite a libertação da crença de que a vida pudesse ser uma 'grandeza fixa ${ }^{76}$, uma dimensão congelada que não corresse nenhum risco de perecer, que pudesse deixar de comportar-se de maneira instável, sem relação com o tempo, sem relação com o movimento, sem relação com um 'vir a ser'. Fazer da vida uma grandeza fixa é o que quer a moral quando cria seus valores, valores esses que se pretendem externos à vida enquanto acontecimento, isto é, enquanto algo que oscila, se expande, vai, vem, volteia e ameaça tudo aquilo que quer se conservar em uma forma perene, numa unidade estanque, numa configuração absoluta, imutável. Nesse sentido é interessante destacar que Nietzsche falará de uma saúde instável ao invés de uma saúde robusta 77 . Ao oferecer um "sentido" à vida, uma razão suficiente o bastante para torná-la razoável frente às nossas expectativas de prazer e autoconservação - como se a vida carecesse incessantemente de razão ${ }^{78}$, a moral busca com isso uma fuga da vida enquanto vir a ser inexplicável moral e racionalmente; a razão é presunçosa quando quer eliminar da vida o seu movimento, seu incessante 'vir a ser'. A suposição de um sujeito capaz de erigir leis universais do conhecimento surge antes da "necessidade interior de reconhecer cada objeto em si, em sua própria essência, como um objeto idêntico a si mesmo, portanto existente por si mesmo e, no fundo, sempre igual e imutável, em suma, como uma substância"79; mas tal suposição, questão fundamental da metafísica, se esquece de que também essa 'lei universal' veio a ser. "Para Nietzsche, a lógica mesma é algo que veio-a-ser." ${ }^{\prime 80}$

A dor, a doença, é uma perspectiva externa à razão. “A confiança na razão, (...) é, sendo confiança, um fenômeno moral"s1. A lenta e prolongada dor faz com que um filósofo desconfie das razões que até então serviram para se autoconservar,

75 NIETZSCHE, F., Humano, demasiado humano, §96, p. 67.

76 NIETZSCHE, F., Humano, demasiado humano, §16, p. 25.

77 NIETZSCHE, F., Gaia ciência, prefácio , §3, p. 12.

78 NIETZSCHE, F., $O$ nascimento da tragédia, prefácio , §5, p. 20.

79 NIETZSCHE, F., Humano, demasiado humano, §18, p. 27.

80 MÜLLER-LAUTER, W., Sua filosofia dos antagonismos e os antagonismos de sua filosofia, p. 40.

81 NIETZSCHE, F., Aurora, prefácio §4, p. 13. 
para a manutenção de sua humanidade, de sua serenidade, na medida em que por meio da dor, da doença, toda estabilidade entra em colapso e o risco da extinção de si ameaça cada vez mais, pois nela "queimamos como madeira verde" 82 . Nesse sentido, a questão de Nietzsche não poderá ser "o que virá a ser do pensamento que é submetido aos progressos da razão?", mas o que virá a ser do pensamento mesmo que é submetido à 'pressão' da doença? ${ }^{83}$ 'Não somos [nós, filósofos] batráquios pensantes, não somos aparelhos de objetivar e registrar, de entranhas congeladas temos de continuamente parir nossos pensamentos em meio a nossa dor". ${ }^{84}$

No entanto, malgrado a centralidade da dor e da doença nos prefácios de 1886, Nietzsche não pretende fazer o que seria uma 'filosofia da dor', ou da doença, mas, ao contrário, propõe antes uma doutrina da saúde ${ }^{85}$. Apesar da importância da dor como ponto de partida para a liberação do espírito, para uma suspeita com relação à moral, Nietzsche afirma ser preciso fazer uma filosofia que parta da saúde e não da doença.

Pois desde que se é uma pessoa, tem-se necessariamente a filosofia de sua pessoa: mas há aqui uma notável diferença. Num homem são as deficiências que filosofam, no outro as riquezas e forças. O primeiro necessita de sua filosofia, seja como apoio, tranquilização, medicamento, redenção, elevação, alheamento de si; no segundo ela é apenas um formoso luxo, no melhor dos casos a volúpia de uma triunfante gratidão (...). Mas naquele outro caso, mais freqüente, em que as crises fazem filosofia, como em todos os pensadores doentes - e talvez os pensadores doentes predominem na história da filosofia - que virá a ser do pensamento que é submetido à 'pressão' da doença?(...) e, se tais afirmações ou negações do mundo em peso, (...) tomadas cientificamente, não têm o menor grão de importância, fornecem indicações tanto mais preciosas para o historiador e psicólogo, enquanto sintomas do corpo, como afirmei, de seu êxito ou fracasso, de sua plenitude, potência, soberania na história, ou então de suas inibições, fadigas, pobrezas, de seu pressentimento do fim, sua vontade de fim $^{86}$.

O que Nietzsche estaria querendo dizer quando distingue uma filosofia que parte das deficiências e outra que parte das riquezas e forças? Seriam a doença, a dor, as crises do convalescente, deficiências? Seriam dispensáveis para uma filosofia nobre, forte, rica? Não é bem o que parece se compararmos com passagens do tipo: O mundo é pobre para quem nunca foi enfermo o bastante para esta "volúpia do inferno": (...) e sendo como sou, forte o bastante para converter mesmo o

\footnotetext{
82 NIETZSCHE, F., Gaia ciência, prefácio §3, p. 13.

83 NIETZSCHE, F., Gaia ciência, prefácio, §2, p. 11.

84 NIETZSCHE, F., Gaia ciência, prefácio §3, p. 13.

85 NIETZSCHE, F., Humano, demasiado humano II, prefácio, §2, p. 09.

86 NIETZSCHE, F., Gaia ciência, prefácio §2, p. 10.
} 
mais discutivel e perigoso em vantagem ${ }^{87}$; ou, retomando o que já havia colocado antes: E no que toca à doença: não estaríamos quase tentados a perguntar se ela é realmente dispensável para nós? Apenas a grande dor é o extremo liberador do espírito $^{88}$. A grande questão é: estar doente é ser doente? Como um pensamento pode responder, agir, reagir, à pressão da doença? Uma filosofia forte, rica, corre o risco de se ver submetida a esse perigo, a essa pressão? Ou apenas uma filosofia por assim dizer fraca corre esse risco? Que relação poderia haver entre potência, plenitude e doença? Que critérios Nietzsche usa pra distinguir plenitude e pobreza? Seria possível falar de uma pobreza do mais rico? ${ }^{89}$

Vem a calhar a esse respeito a questão colocada por Nietzsche a partir da relação dos gregos com um excesso, excesso da sensação de dor.

\begin{abstract}
Adivinha-se em que lugar era colocado, com isso, o grande ponto de interrogação sobre o valor da existência. Será o pessimismo 'necessariamente' o signo do declínio, da ruína, do fracasso, dos instintos cansados e debilitados - como ele o foi entre os indianos, como ele o é (...) entre nós, homens e europeus "modernos"? Há um pessimismo da 'fortitude'? Uma propensão intelectual para o duro, o horrendo, o mal, o problemático da existência,devido ao bem-estar, a uma transbordante saúde, a uma 'plenitude' da existência? Há talvez um sofrimento devido à própria superabundância?'
\end{abstract}

Tal problema é importante se considerarmos que Nietzsche identifica a grande saúde a um tipo de pessimismo, um "pessimismo da fortitude", e é em relação ao pessimismo em geral que ele irá distinguir dois sentidos de doença. Há um pessimismo dos abstinentes, pessimismo dos românticos, pessimismo que busca repouso, que sofre de um empobrecimento de vida, que busca silêncio, quietude ${ }^{91}$; e há um pessimismo da fortitude, um pessimismo que tem boa vontade com relação ao pessimismo $^{92}$, um valente pessimismo, isto é, que não toma o sofrimento, a privação, a solidão, como objeções à vida, mas antes como estímulos, como tarefa: "Minha $t a$ refa — onde estava ela? (...) Que fazer para suportar essa, a maior das privações?"93 A saúde é esse retorno a si ${ }^{94}$, essa arte da transfiguração que é capaz de se iludir, que sabe que a vida quer ilusão, artifício, que está além do bem e do mal, que é de toda

87 NIETZSCHE, F., Ecce homo, Por que sou tão inteligente, p. 43.

88 NIETZSCHE, F., Gaia ciência, prefácio, §3, p. 13.

89 NIETZSCHE, F., O anticristo, Da pobreza do mais rico, p. 139.

90 NIETZSCHE, F., Nascimento da tragédia, prefácio §1, p.14.

91 NIETZSCHE, F., Gaia ciência, §370, p. 272.

92 NIETZSCHE, F., Humano, demasiado humano II, prefácio §2, p. 09.

93 NIETZSCHE, F., Humano, demasiado humano II. prefácio §3, p. 10.

94 NIETZSCHE, F., Humano, demasiado humano, prefácio §5, p. 12; Humano, demasiado humano II, prefácio, $§ 2$, p. 09. 
indiferente à moral —e por isso é imoral ; a saúde é uma disciplina da vontade ${ }^{95}$, uma sabedoria de vida que é capaz de receitar para si a saúde em pequenas doses.

Não há dúvida de que implícito a essa doutrina da saúde há o problema da hierarquia. A hierarquização é justamente o que faz parte da grandeza, pois "quem realizará algo de grande, se não sentir dentro de si a força e a vontade de infligir grandes dores? Saber sofrer é o mínimo: mulheres frágeis e até escravos tornam-se mestres nisso. Mas não sucumbir à aflição e incerteza interior, quando se inflige grande sofrimento e se ouve o grito deste sofrimento - isso é grande, isso faz parte da grandeza." ${ }^{96}$ Se experimentamos contraditórios estados de indigência e felicidade na alma e no corpo ${ }^{97}$, que não façamos desses estados pretextos para maldizer a vida, mas que façamos desses estados um estímulo a mais para 'saborear' a vida ao invés de buscarmos repouso e resignação. A vida nos impõe a necessidade de ordenar o mundo, um mundo "no qual nossa existência seja possível"98, a vida exige de nós grandeza, isto é, saber dar direção $0^{99}$.

95 NIETZSCHE, F., Humano, demasiado humano II, prefácio, §2, p. 09.

96 NIETZSCHE, F., Gaia ciência, §325, p. 215.

97 NIETZSCHE, F., Humano, demasiado humano, prefácio §7, p. 13.

98 NIETZSCHE, F., Fragments Posthumes, v. XIII, (97) 9 [144], automne 1887, p. 80.

99 NIETZSCHE, F., Humano, demasiado humano, §521, p. 243. 


\section{Grandeza, música, saúde e direção: uma crítica à intuição intelectual por Nietzsche}

Humano demasiado humano é o monumento de uma crise ${ }^{100}$, assim como de uma rigorosa disciplina de $\mathrm{si}^{101}$ e de um retorno a $\mathrm{si}^{102}$. Nietzsche não foi seu escritor, embora tenha sido seu autor; o verdadeiro escritor de Humano demasiado humano foi Peter Gast. "Eu [Nietzsche] ditava, a cabeça enfaixada e dolorida, ele [Peter Gast] escrevia; ele foi o escritor, eu o autor"103. Tal obra marca o momento em que Nietzsche conseguira alcançar alguma serenidade para poder falar de seus "longos anos intermediários de íntima solidão e privação" 104 , marca já, portanto, de uma superação da doença, isto é, a conquista de um poder opor-se a ela, de obtenção de um distanciamento que tornou possível poder observá-la. Tal distanciamento é sinal de que Humano demasiado humano não é um livro de alguém que ama a doença e que nesse amor está completamente chafurdado, mas de alguém que conquistou uma saúde para poder observar, encarar a doença — o que já demonstra não uma suma rejeição dela, mas poderíamos mesmo dizer que já está presente aí um acolhimento da doença, uma gratidão, no mínimo um respeito por ela — de alguém que conquistou uma saúde que o tornou capaz de esquecer, de deixar para trás, pois "enquanto ainda amamos, não pintamos quadros assim; ainda não "observamos", não nos colocamos de tal maneira à distância, como tem de fazer o observador."105

Que tal obra seja a expressão de um mínimo de vida ${ }^{106}$ pelo qual Nietzsche passara, pode se ver no que o autor considera seu mais forte ensinamento: "uma doutrina da saúde, que pode ser recomendada como disciplina da vontade." 107 Que tal livro tenha sido escrito sob as condições mais desfavoráveis, sob a pressão da doença ${ }^{108}$, da dor, da solidão, não o faz uma obra pessimista, cansada, triste, mas pelo contrário,

\footnotetext{
100 NIETZSCHE, F., Ecce Homo, "Humano demasiado humano", §1, p. 69.

101 Ibid. $\$ 5$, p. 72.

102 Ibid. $\$ 3$, p. 71.

103 Ibid. $\$ 5$, p. 73.

104 NIETZSCHE, F.,. Humano, demasiado humano II, prólogo, §5, p. 08.

105 NIETZSCHE, F., Humano, demasiado humano II, prólogo, §2, p. 08.

106 NIETZSCHE, F., Humano, demasiado humano II, prólogo, §5, p. 12.

107 NIETZSCHE, F., Humano, demasiado humano II, prólogo, §2, p. 09.

108 NIETZSCHE, F., Ecce homo, Humano, demasiado humano, §4, p. 72.
} 
experimentar e sofrer a doença foi a condição para que Nietzsche pudesse arrancar de si a conclusão de que "um sofredor não tem direito ao pessimismo!"109, do mesmo modo como a dor e a abstinência não devem ser tomados como objeções à vida e fazer dos homens seres sempre soturnos, de tom sempre sofredor e abstinente. "A um olhar e uma simpatia refinados não escaparia (...) aquilo que talvez seja o encanto desses escritos - que ali fala um homem sofredor e abstinente, como se não fosse um sofredor e abstinente. (...) A arte de parecer jovial, objetivo, curioso, sobretudo sadio e malicioso - e num doente isso é, quer me parecer, o seu "bom gosto" "110. Tomar a dor como estímulo. Quem é forte para tanto? Não seria isso um otimismo, acreditar que se possa superar a dor sem rejeitá-la? Ou, ainda, não seria mesmo o contrário, não estaria aí presente uma disposição pessimista de Nietzsche? —mas como pessimismo, logo ele que tão nobremente fala que é preciso "afirmar a vida tal qual ela é"?!Sim, tanto uma opção quanto outra, tanto otimismo quanto pessimismo: um "otimismo para fins de restabelecimento, para algum dia poder voltar a ser pessimista"111; e um pessimismo que tem boa vontade para com o pessimismo "e, assim, não mais um romântico" ${ }^{112}$, isto é, que não quer extirpar da vida as condições mais desfavoráveis às quais muitas vezes somos submetidos, pois sabe tomar a dor, a desilusão, o fastio, a solidão, a doença, como meios para se conquistar um grande fortalecimento espiritual, uma abundância de saúde ${ }^{113}$, uma nova saúde ${ }^{114}$, uma tal que não toma a razão como medida da vida, pois é capaz de notar que a "irracionalidade de uma coisa não é um argumento contra sua existência, mas sim uma condição para ela." ${ }^{115}$

De que maneira a música de Wagner poderia contribuir para entendermos o que Nietzsche está querendo dizer com saúde/doença? Tal articulação entre música, saúde e doença, tem por pressuposto o fato de que Nietzsche não ouve a música como uma linguagem universal, mas como sendo a transmissão de uma medida de sensibilidade ${ }^{116}$. Ora, podemos então perguntar, qual medida de sensibilidade Nietzsche escuta na música wagneriana? Sob qual economia de sentimentos Wagner conduz, dá direção, guia, sua música? Sob qual regime econômico ele dispende, retém, estende, acelera ou ralenteia suas melodias, seu ritmo, suas harmonias? Sob qual ritmo sua música anda, marcha, corre, dispara, dança? Sob quais margens sua

\footnotetext{
109 NIETZSCHE, F., Humano, demasiado humano II, prólogo, §5, p. 12.

110 NIETZSCHE, F., Humano, demasiado humano II, prólogo, §5, p. 11.

111 NIETZSCHE, F., Humano, demasiado humano II, prólogo, §5, p. 12.

112 NIETZSCHE, F., Humano, demasiado humano II, prólogo, §2, p. 09.

113 NIETZSCHE, F., Humano, demasiado humano II, prólogo, §5, p. 12.

114 NIETZSCHE, F., Humano, demasiado humano II, prólogo, §6, p. 13.

115 NIETZSCHE, F., Humano, demasiado humano, §515, p. 243.

116 NIETZSCHE, F., Opiniões e sentenças, §171, p. 80.
} 
música joga? Que postura ela mantém ante os obstáculos, ante os elementos que lhe oferecem resistência? Sob quais limites sua música se desenvolve, sob qual coação, isto é, como ela resolve, harmoniza, dribla as tensões que encontra pelo caminho? O que pretende ela ultrapassar - toda e qualquer tensão?

Muitas vezes a arte se exerce com o objetivo de aliviar a vida ${ }^{117}$, e com a música não é diferente. No aforismo intitulado "Música e doença", Nietzsche adverte o leitor para o perigo que a música oferece — que no caso da música moderna está no efeito grandioso que ela sugere ao ouvinte:

- O perigo da música está em que nos põe nos lábios a taça do voluptuoso e grandioso, de modo tão cativante e com tal aparência de êxtase moral que até mesmo o indivíduo nobre e comedido sempre bebe algumas gotas a mais. Mas essa mínima intemperança, continuamente repetida, pode enfim acarretar um abalo e solapamento da saúde espiritual, mais profundo do que qualquer excesso grosseiro poderia produzir (...). ${ }^{118}$

O que acarreta o abalo da saúde espiritual é a desmedida; a intemperança é indício de adoecimento; querer sempre mais e mais é ceder à sedução e esperança que o excesso oferece, de por meio da próxima gota a ser bebida - sempre adiada à uma próxima vez que parece nunca completar-se, nunca chegar a termo, e que por isso sempre relança novamente à próxima vez, e assim sucessivamente, ad infinitum - se poder alcançar algo, enfim, grandioso, uma volúpia cada vez maior, um estado além de toda coação. Sugerindo isso aos nossos ouvidos, a música moderna —isto é, a música de Wagner- quer ultrapassar todos os limites, quer elidir tudo o que coage por meio de uma aparência de "êxtase moral". Mas tal êxtase, assim Nietzsche parece querer dizer, tal estar exterior a todos os limites, estar mergulhado num grandioso que a todos limites e beiras excede, que é pura expansão - isso adoece, debilita, solapa qualquer saúde, de maneira que para retornar à saúde seria preciso abrir caminho para os abraços de uma "esposa mais simples e mais humana." 119

Uma grande arte, uma tal que tenha espírito, não é uma arte do grandioso. O grandioso é o motivo principal da corrupção do estilo:

- Querer "mostrar" mais sensibilidade por uma coisa do que realmente se "tem", corrompe o estilo, na linguagem e em todas as artes. Toda grande arte tem, isto sim, a tendência contrária: adora, como todo indivíduo moralmente significativo, deter o sentimento no caminho e não deixá-lo ir até o fim. Esse pudor da semivisibilidade do sentimento se observa da maneira mais bela em Sófocles, por exemplo; e parece que os traços do sentimento se transfiguram, quando este se apresenta mais sóbrio do que é. ${ }^{120}$

\footnotetext{
117 NIETZSCHE, F., Humano, demasiado humano I, §148, p. 108.

118 NIETZSCHE, F., Opiniões e sentenças, §159, p. 73.

119 NIETZSCHE, F., Opiniões e sentenças, §159, p. 74.

120 NIETZSCHE, F., O andarilho e sua sombra, §136, p. 227.
} 
Querer causar a impressão de se ter um poder maior do que se pode, de uma hiperpotência, de uma potência que desconhece qualquer limite, que promete algo grandioso e que por isso não detém minimamente seus impulsos, seus sentimentos, pois tudo quer revelar, dominar, controlar, saber, sentir, aí não há seletividade, pois não há limites, e não havendo limites não pode haver hierarquia. A supressão de todos os limites adoece, corrompe a unidade de estilo, faz os impulsos se dissolverem numa anarquia, isto é, numa pura dispersão. Por saúde, estilo e espírito Nietzsche muitas vezes quer dar a entender algo semelhante: o importante não é ter mais, nem menos, mas o que se faz com o que se tem, a direção que é dada aos impulsos, o como se conduz em meio à multiplicidade e tensão dos impulsos que constituem o mundo tanto quanto nós mesmos. Segundo Nietzsche, o que a música moderna faz ao colocar em nossos lábios o grandioso é "querer mostrar mais sensibilidade por uma coisa do que se tem", é não se deter, é querer superar toda e qualquer tensão com o intuito de exceder todo conflito, de estar além da guerra, de todo e qualquer limite, de tudo o que nos incomoda, que nos perturba; a música moderna quer nos fazer crer que o excesso se liga à felicidade, a um grandioso em si.

Grandioso e grandeza assim diferem: no grandioso está a promessa de que elidindo a tensão, dando livre curso a todos os impulsos sem opôr-lhes resistência alguma, encontraremos repouso, felicidade, satisfação completa; já por grandeza Nietzsche quer dar a entender um princípio de seletividade que constrói e edifica sem se furtar à tensão, sem querer estar sob condições ideais, pois não concebe a felicidade negativamente ${ }^{121}$, isto é, não põe a paz acima da guerra, não nega a guerra mas se afirma por meio dela. A arte do grande ritmo, do grande estilo consiste em

comunicar um estado, uma tensão interna de pathos por meio de signos, incluído o tempo desses signos - eis o sentido de todo estilo; e considerando que a multiplicidade de estados interiores é em mim extraordinária, há em mim muitas possibilidades de estilo. ${ }^{122}$

A questão do estilo é: como forçar e criar uma unidade estando em meio à multiplicidade? A necessidade de forçar uma unidade está em que, por um lado, chafurdado na multiplicidade tudo é pura dispersão, dissolução, ausência de si; por outro lado, o homem não pode abarcar todas as perspectivas, todos os impulsos, o homem é um ser finito, nem onisciente, nem onipotente, nem onividente, mas um animal sujeito ao erro, à ilusão, à dor, à morte, ao aniquilamento e esfacelamento, incapaz de tudo calcular e prever. Tudo calcular seria possível caso fôssemos oniscientes, mas não temos potência o suficiente para tanto, não podemos ver, ouvir, cheirar, tatear, conhecer a

121 NIETZSCHE, F., Gaia ciência, prólogo, §2, p.11.

122 NIETZSCHE, F., Ecce homo, Por que escrevo tão bons livros, §4, p. 54. 
partir do que seria uma perspectiva universal e absoluta. Estamos subordinados à condições finitas, e estar subordinado a tais condições é estar sob a perspectiva da necessidade, é saber que a vida acontece por necessidade, isto é, que ela não acontece por mero capricho, por mero arbítrio de uma consciência, de uma vontade; estar sob a perspectiva da necessidade não nos faz seres universais, seres que podem tudo prever, tudo calcular, capazes de falar em nome de um Absoluto. "Deveríamos poder calcular previamente cada ação isolada, se fôssemos oniscientes, e do mesmo modo cada avanço do conhecimento, cada erro, cada maldade"123, mas não somos oniscientes. "Mesmo os homens raros, cujo pensamento vai além de si mesmos, não lançam os olhos a essa vida universal, mas somente a partes limitadas dela"124. O pressuposto para a afirmação de Nietzsche sobre a impossibilidade de assumirmos uma perspectiva universal, ilimitada e total sobre o mundo, sobre a vida, e de termos potência apenas para uma perspectiva pontual, limitada, finita, está em sua crítica à intuição intelectual:

- Por mais que alguém creia ter se desabituado da religião, isso não sucedeu a ponto de não ter alegria em experimentar sentimentos e disposições religiosas sem conteúdo intelectual, como na música, por exemplo; e quando uma filosofia procura justificar as esperanças metafísicas e a profunda paz de espírito que delas se pode obter, e quando nos fala, por exemplo, de "todo o Evangelho seguro que há no olhar das Madonas de Rafael", acolhemos tais sentenças e explicações com uma disposição particularmente efusiva: aqui é mais fácil para a filosofia demonstrar; o que ele quer dar encontra um coração que tem prazer em aceitar. Nisto se percebe que os espíritos livres menos ponderados se chocam apenas com os dogmas, na realidade, e conhecem bem o encanto do sentimento religioso; é doloroso para eles perder este por causa daqueles. - A filosofia científica deve estar alerta para não introduzir erros com base em tal necessidade - uma necessidade adquirida e, portanto, também passageira - mesmo os lógicos falam de "intuições" da verdade na moral e na arte (por exemplo, da intuição de que a "essência das coisas é uma"): o que lhes deveria ser proibido. Entre as verdades diligentemente deduzidas e semelhantes coisas "intuídas" permanece o abismo intransponível de que devemos aquela ao intelecto e estas à necessidade. A fome não demonstra que "existe" um alimento para saciá-la; ela deseja esse alimento. "Intuir" não significa reconhecer num grau qualquer a existência de uma coisa, mas sem tê-la como possível, na medida em que por ela ansiamos ou a ela tememos; a "intuição" não faz avançar um passo na certeza. - Acreditamos naturalmente que as partes de uma filosofia tingidas pela religião estão mais bem demonstradas que as outras, mas no fundo é o contrário, temos apenas o desejo íntimo de que 'possa' ser assim - isto é, de que o que torna feliz seja também verdadeiro. Esse desejo nos faz ver como bons motivos ruins. ${ }^{125}$

A “intuição intelectual” é uma noção que possui forte lastro na teologia medieval, o que no entanto não elimina o fato de ter estado presente na filosofia

\footnotetext{
123 NIETZSCHE. Humano, demasiado humano, §106, p. 76.

124 Ibid. 333 , p. 38.

125 NIETZSCHE, F., Humano, demasiado humano, §106, p. 92.
} 
moderna. Os padres latinos a utilizavam para se referir ao que seria um "olhar do espírito" capaz de imediatamente apreender uma realidade em sua totalidade, um "olhar intelectual" capaz de captar via intuição uma existência em sua essência mesma ${ }^{126}$. Já para Nietzsche, a intuição intelectual é o resquício de uma sensibilidade religiosa presente dentro da filosofia, isto é, de uma profunda ânsia por paz de espírito, e que, ao contrário do que promete, não é capaz de avançar nenhum passo na certeza. A intuição intelectual é uma esperança metafísica de se obter a satisfação das necessidades, uma ânsia íntima por tornar presente o objeto capaz de satisfazer o desejo, isto é, que fosse capaz de eliminar o sentimento de privação, de insatisfação. Perder o sentimento religioso, perder a metafísica, a intuição intelectual, perder a paz, seria um evento doloroso justo na medida que é em relação à dor, à doença, à não conservação, às condições desfavoráveis em geral, que à intuição intelectual quer se proteger. Tal como a música moderna, a religião quer a vitalidade a qualquer preço; em ambas reina um excesso de sentimento. ${ }^{127}$

A crença na intuição intelectual põe à prova o caráter intelectual daquele que nela crê ${ }^{128}$. Ela é uma presunção da razão que não quer reconhecer limites, é pois uma razão hipertrofiada. Poderíamos parafrasear a frase já citada de Nietzsche e dizer: “Querer mostrar mais 'razão' do que se tem corrompe o estilo”, abala a saúde, debilita, adoece. Isso é sinal de que a doença não necessariamente é decorrência de uma privação, pois pode advir também por excesso. "O homem moderno é fraco, porque é puramente artifício (...). Ele configura aquele tipo de aleijão por excesso, que Zaratustra tanto ironizava, o aleijado cuja monstruosidade não consiste na privação de um órgão, mas no hiperdesenvolvimento de um deles, em detrimento da integridade do corpo." 129

Seja por um hipo, seja por um hiper desenvolvimento, cada doença possui sua configuração própria, sua lógica própria, sua estratégia, seu mecanismo próprio, singular. A quais referências, sentidos e coordenadas cada doença está referida, por onde joga, isso não é possível determinar de antemão, como que por uma intuição intelectual, mas é preciso prestar olhar, prestar ouvidos, deixar-se contaminar por sua própria maneira de se conduzir, de guiar, de evoluir, de percorrer, de seduzir, perceber aonde quer vencer, o que pretende ultrapassar, eliminar, rejeitar, aonde não consegue não perder, "os esconderijos onde [seu] ideal faz morada onde tem suas masmorras e sua última trincheira, (...) este submundo do ideal." ${ }^{\prime 130}$

\footnotetext{
126 FONTAINE, J.-M., Le vocabulaire latin de la philosophie, p. 83.

127 NIETZSCHE, F., Humano, demasiado humano I, §106, p. 135.

128 Ibid. $\S 153$, p. 110.

129 GIACÓIA, O., Nietzsche como psicólogo, p. 89.

130 NIETZSCHE, F., Ecce homo, Humano demasiado humano, §1, p. 69.
} 
Um voltar-se sobre si mesmo permitiu a Nietzsche extrair um saber não apenas acerca da doença que ele por experiência própria experimentou, mas permitiu-lhe também prestar um olhar mais sutil aos caminhos do que viu ser o desenvolvimento de uma doença na modernidade, na arte, na religião na filosofia, nas ciências.

Após uma interrogação de si mesmo, experimentação consigo mesmo, aprendemos
a olhar mais sutilmente para todo o filosofar que houve até agora; adivinhamos me-
lhor os involuntários desvios, vias paralelas, pontos de repouso, pontos solares do
pensamento, aos quais os pensadores que sofrem são levados e aliciados justamente
por sofrerem; sabemos agora para onde o corpo doente, com a sua necessidade, in-
conscientemente empurra, impele, atrai o espírito - para o sol, sossego, brandura,
paciência, remédio, bálsamo em todo e qualquer sentido. ${ }^{131}$

Uma necessidade metafísico-intelectual via por onde se alcançaria uma pretendida imortalidade, uma eternidade, o fim de todas as dores e o que seria uma saúde perene, robusta, eternamente conservada, o remédio de todos os remédios, que ruma sempre à uma cada vez maior absolutização de si, à eliminação de todo conflito, é a medida de sensibilidade que a Nona Sinfonia de Beethoven sugere a Nietzsche:

- Podemos ver como é forte a necessidade metafísica, e como é difícil para a natureza livrar-se dela enfim, pelo fato de mesmo no livre-pensador, após ele ter se despojado de toda metafísica, os mais altos efeitos da arte produzirem facilmente uma ressonância na corda metafísica, por muito tempo emudecida ou mesmo partida; quando, em certa passagem da Nona sinfonia de Beethoven, por exemplo, ele se sente pairando acima da Terra numa cúpula de estrelas, tendo o sonho da "imortalidade" no coração: as estrelas todas parecem cintilar em torno dele, e a Terra se afastar cada vez mais. - Tornando-se consciente desse estado, ele talvez sinta uma funda pontada no coração e suspire pela pessoa que lhe trará de volta a amada perdida, chame-se ela religião ou metafísica. Em tais momentos será posto à prova o seu caráter intelectual. ${ }^{132}$

E a música de Wagner, que medida de sensibilidade Nietzsche escuta nela? Nietzsche inicia o prólogo de $O$ Caso Wagner afirmando que se ele louva Bizet em detrimento de Wagner, isso não é pura malícia de sua parte, mas algo sobre o qual não se brinca: Voltar as costas para Wagner foi para mim um duro destino. ${ }^{133}$ O quanto lhe foi penoso resistir e ultrapassar-se a si mesmo, lhe acarretando uma grande solidão, podemos ver no capítulo nono, "Como me libertei de Wagner", parágrafo primeiro, de Nietzsche contra Wagner:

\footnotetext{
131 NIETZSCHE, F., Gaia ciência, prólogo, §2, p.11.

132 NIETZSCHE, F., Humano, demasiado humano I, §153, p.110.

133 NIETZSCHE, F., Le cas Wagner, p. 09.
} 
Quando eu retomei minha marcha solitária, eu tremia; logo após eu caí doente, mais que doente, fatigado, cansado, a morrer por estar radicalmente decepcionado por tudo que restava a nós (...); a morrer, de desgosto por toda essa hipocrisia idealista e esse enfraquecimento de consciência (...), fatigado, enfim (...) do torturante, do implacável pressentimento de que eu estaria condenado a uma desconfiança ainda maior, a um profundo desgosto, a uma solidão mais profunda do que nunca. Pois eu jamais tivera alguém além de Wagner. ${ }^{134}$

No prólogo de O Caso Wagner, Nietzsche situa sua relação com Wagner a partir dos jogos saúde/doença, e decadência/modernidade. Tal como Wagner, Nietzsche se considera "uma criança desse século", ou seja, um decadente, com a única diferença que ele, Nietzsche, resistiu com todas suas forças contra seu tempo, realizando aquilo que se espera de um filósofo - triunfar sobre seu tempo, fazer-se "intemporal", "intempestivo". 135

Mas o que Nietzsche entende por decadência, isso que ele considera ter sido sempre sua preocupação mais íntima, e que para ele caracterizaria a modernidade? "Bem e mal": esse não é senão um caso particular desse problema (...); vida empobrecida, um querer-morrer, um grande cansaço. A moral 'diz não'à vida. ${ }^{136} \mathrm{Na}$ decadência, Nietzsche vê um enfraquecimento dos instintos ${ }^{137}$. A "abnegação”, este é o princípio mesmo da decadência, um querer-morrer, tanto na arte como na moral. ${ }^{138}$

O que nos interessa aqui é avaliar como Nietzsche interliga Wagner, decadência e os valores da modernidade, e como a partir daí ele, Nietzsche, pôde situar Wagner como um caso de doença do qual ele teria de se libertar caso quisesse restaurar sua saúde:

Tomar parte contra tudo o que havia em mim de doença, nisto compreende-se Wagner, Schopenhauer, assim como todos os modernos sentimentos de "humanidade"; ou, quando Nietzsche afirma: Minha experiência mais marcante foi uma "cura". Wagner não é senão uma das minhas doenças. Não que eu queira me mostrar ingrato em relação a essa doença. ${ }^{139}$

Segundo Nietzsche, cada época possui um determinado critério por meio do qual elege seus valores, de modo que ou ela privilegia as virtudes de uma vida crescente (moral dos Senhores), e aí resiste com todas as suas forças a uma vida decadente, ou ela se coloca a si mesma como uma vida declinante (moral

\footnotetext{
134 NIETZSCHE, F., Nietzsche contre Wagner, p.130.

135 Ibid. p. 10.

136 Ibid. p. 10.

137 NIETZSCHE, F., Le cas Wagner, §5, p. 33.

138 NIETZSCHE, F., Nietzsche contre Wagner, p. 119.

139 NIETZSCHE, F., Le cas Wagner, p. 10.
} 
decadente), privilegiando os valores de uma cultura decadente, e nesse caso ela detesta tudo aquilo que se justifica por uma plenitude, por uma superabundância de forças. ${ }^{140}$ Enquanto a moral dos Senhores diz sim aos instintos - a estética está indissoluvelmente ligada à condições "biológicas" — a moral decadente diz não aos instintos; "Deus", “Além", “abnegação", são noções por meio das quais a moral decadente busca suprimir essa vida em vista de uma vida melhor. Enquanto a primeira dispende sua riqueza às coisas, transfigurando o mundo, embelezando-o, a segunda o empobrece, o descolore, diz não ao mundo, lhe dá um sentido pejorativo. E aquilo contra o que, segundo Nietzsche, temos de nos precaver é justo da má-fé e da duplicidade de instintos que nos fazem incorrer em equívocos, nos impedindo de ver que a moral do Senhor e a moral declinante são direções antitéticas. $^{141}$

Sua força está no equívoco, no "duplo sentido", em tudo aquilo que persuade os he-
sitantes sem os fazer compreender claramente "do que" eles são persuadidos. Nesse
sentido, Wagner é um sedutor de grande classe. Ele não é, nas coisas do espírito,
nada senão fadiga, extenuação, apresentação de um perigo mortal que denigre o
mundo, que sua arte defende em segredo. - É o mais sombrio obscurantismo que
ele oculta em véus luminosos do Ideal. ${ }^{142}$

É nessa "contradição de valores" que Nietzsche diagnostica um sintoma do homem moderno, que inconscientemente diz sim quando em verdade está dizendo não (ao mundo, à vida). Querendo pôr a nu esse conflito, essa inconciliável oposição de valores presente na modernidade, Wagner surge como o caso clínico mais "revelador". ${ }^{43}$

Segundo Nietzsche afirma, Wagner teve como pano de fundo de sua música o problema da "saúde", ou melhor, da salvação - Nele vemos sempre alguém que quer ser salvo a qualquer custo. ${ }^{144}$ Em Tannhäuser se vê a inocência salvando de preferência os pecadores "interessantes"; no Navio Fantasma, é o judeu errante que, se fixando no casamento, cessa de errar e assim se salva ${ }^{145}$, é o tema do homem que se salva pelo amor. Nietzsche segue assim apontando a obsessão por "salvar" comparecendo em diversas óperas wagnerianas, mas também aponta um momento que não se liga concretamente às óperas de Wagner, momento em que confronta Wagner com Goethe, afirmando que Wagner quer salvar Goethe ${ }^{146}$ :

\footnotetext{
140 NIETZSCHE, F., Le cas Wagner, p. 85.

141 Ibid. p. 87.

142 Ibid. p. 73.

143 Ibid. p. 91.

144 Ibid. §3, p. 22.

145 Ibid. §3, p. 22.

146 Ibid. §3, p. 26.
} 
O que teria pensado Goethe de Wagner? Goethe um dia perguntou-se qual o perigo ameaçava todos os românticos. E sua resposta foi: "asfixiar-se ao preço de ruminar absurdidades morais e religiosas". Breve: 'Parsifal'... ${ }^{147}$

Em Wagner o mal é abolido ${ }^{148}$; Wagner quer abolir a infelicidade do mun$\mathrm{do}^{149}$, e é justamente nesse momento que ele se torna decadente, é justo nesse momento que ele acaba por nos arruinar a saúde ${ }^{150}$, assim o fazendo quando se mostra incapaz de tomar a dor como um estímulo vital ${ }^{151}$, algo que, ao contrário de Wagner, Goethe, ao ver de Nietzsche, foi capaz de realizar. ${ }^{152}$

$\mathrm{Na}$ busca por redenção, Wagner acreditou na Revolução e fez de Siegfried o arquétipo do revolucionário:

Como banir do mundo a infelicidade?" (...) Apenas podemos fazê-lo declarando guerra às "convenções" (aos costumes, à moral). Foi o que fez Siegfried. (...) Seu nascimento é já uma declaração de guerra, pois ele nasceu do adultério e do incesto... ${ }^{153}$

Segundo Nietzsche, Wagner fracassou na sua empreitada, uma catástrofe se lhe deparou quando viu que o "novo mundo é tão ruim quanto o antigo"154. É então quando ele se encontra com Schopenhauer, e o otimismo que antes depositava em sua música se entrechoca com o pessimismo de "O Mundo como Vontade e Representação". Wagner contrai então uma dívida imensa com Schopenhauer, e passa a ver no fracasso de sua própria empreitada o seu objetivo final, a ver no fracasso sua salvação. Tudo vai de través (...). Fracassar aí - não seria esse também um objetivo? ${ }^{155}$

Buscando expressar o inefável, pois parte do princípio de que tudo o que nos derruba, nos oprime, é forte, de que tudo o que nos faz pressentir o inefável é profundo, capaz de atirar a atenção das massas ${ }^{156}$, Wagner acaba por cair no "caos", pois o caos faz pressentir o inefável. ${ }^{157}$

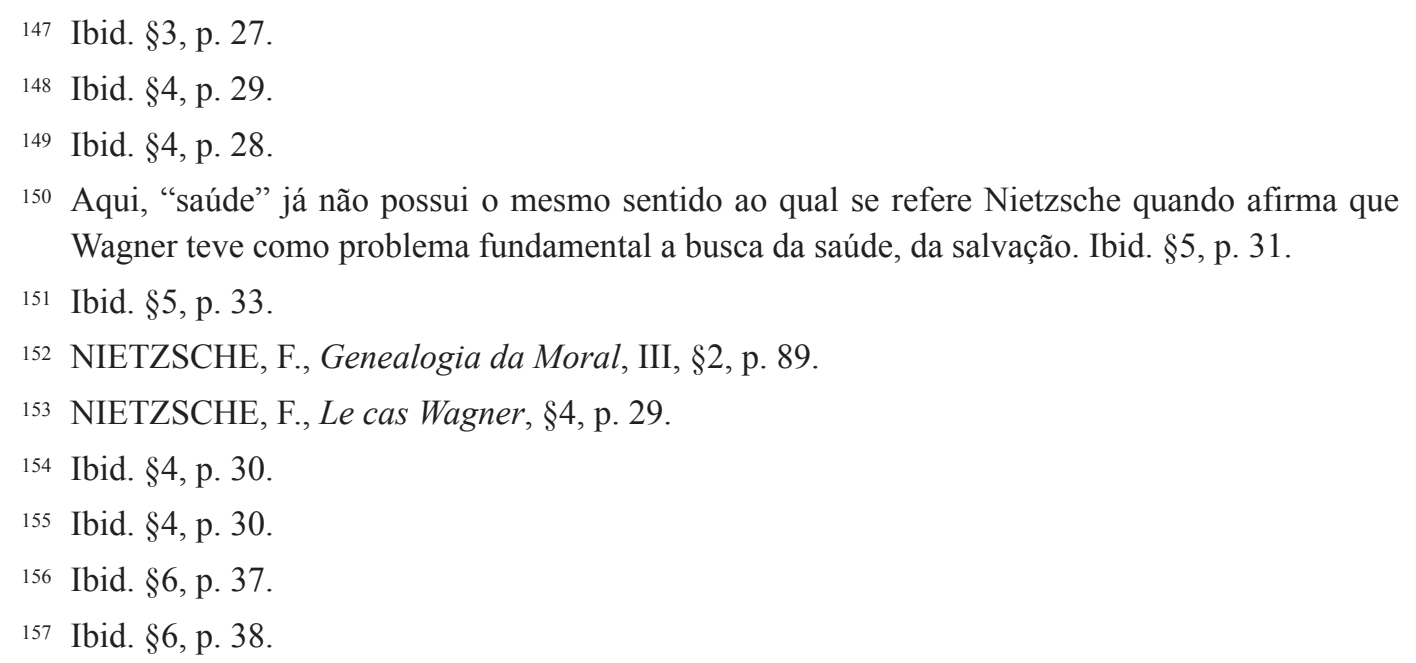


- "Sejamos idealistas!" Para "elevar" a alma das massas, é preciso estar si mesmo numa grande "elevação"... Planemos nobremente nas nuvens, invoquemos incansavelmente o infinito (...). Isso nos faz respeitáveis. ${ }^{158}$

— "O homem corre atrás de sua perda. Quem irá redimir-lhe? O que irá salvá-lo? — Não respondemos. (...) Mas ninguém deve duvidar de que somos nós que o salvaremos, que apenas nossa música é a saúde... (Ver o ensaio de Wagner "A Religião e a Arte"). ${ }^{159}$

Segundo Nietzsche, buscando salvar e seduzir as massas, para tanto tentando apresentar o infinito, Wagner passa a rejeitar a bela melodia em detrimento da "melodia infinita", rejeitando a técnica do contraponto a fim de que a melodia pudesse então apresentar o Ideal ${ }^{160}$. No entanto, na visão de Nietzsche, o que Wagner consegue com isso não é mais do que "denegrir a melodia". ${ }^{161}$

Mas, o que Nietzsche entende aí por "melodia contínua"? A total degenerescência do sentido rítmico, o "caos" no lugar do ritmo... ${ }^{162}$ Nietzsche nos fornece ainda uma imagem para que a compreendamos melhor:

É preciso (...) imaginar, é como se entrássemos no mar e pouco a pouco fôssemos perdendo a sensação dos nossos pés (...): e então não nos resta mais nada senão" nadar". ${ }^{163}$

No entanto, à modernidade de Wagner, Nietzsche contrapõe "uma música mais antiga, onde havia evoluções graciosas e solenes, ou ardentemente apaixonadas, vivas e lentas alternadamente"164; Nietzsche defende uma música que dança ao invés de nadar: tudo que é divino marcha com delicadeza nos pés: primeiro princípio de minha estética. ${ }^{165}$

É com freqüência que vemos Nietzsche tecer elogios a Bizet em O caso Wagner — “me torno melhor quando Bizet vem a mim”. Por que? Acredito poder dizer que é porque Bizet expressa o exato contrário da melodia contínua presente em Wagner:

Ela [Carmen, de Bizet] é rica. Ela é precisa. Ela constrói, organiza, acaba: ela é assim o exato oposto desse verdadeiro pólipo ${ }^{166}$ musical que é a "melodia contínua" ${ }^{167}$

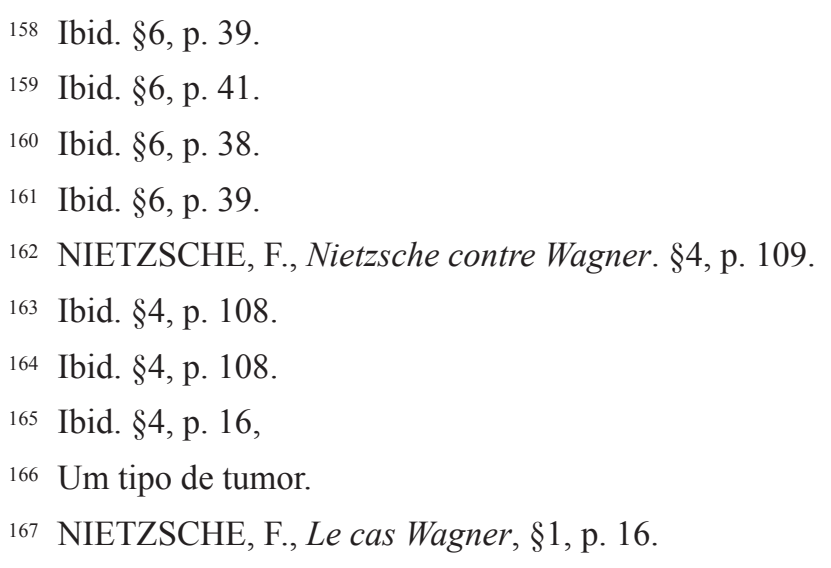


Enquanto Wagner expressa para Nietzsche uma falta de cadência, de ritmo, de dança ${ }^{168}$, em Bizet ele vê uma música ágil, educada, vivaz ${ }^{169}$. Enquanto Wagner expressa um temperamento alemão em suas músicas, Nietzsche vê em Bizet uma alegria mais africana, própria dos países quentes ${ }^{170}$. Enquanto em Wagner transparece um antissemitismo ${ }^{171}$, em Bizet comparece uma sensibilidade mais meridional, morena, bronzeada, queimada. ${ }^{172}$ Em Bizet, o amor não é concebido como uma espécie de "virgem ideal", nem mesmo como compaixão"173, mas como um "fatum", uma "fatalidade". ${ }^{174}$ Travestindo em princípio sua própria falência em conceber um todo orgânico, Wagner foi incapaz de encontrar para si um estilo, manifestando com isso uma "crise de gosto", segundo Nietzsche. ${ }^{175}$ Se Wagner faz com que Nietzsche ponha para si a seguinte questão: “o que meu corpo pode esperar da música?”; Bizet faz com que em Nietzsche "minha melancolia possa escutar e achar um repouso nos redutos e abismos da perfeição: é para isso que eu tenho necessidade de música."176

\footnotetext{
168 NIETZSCHE, F., Nietzsche contre Wagner, §2, p. 108.

169 NIETZSCHE, F., Le cas Wagner, §1, p.16.

170 Ibid. $\$ 2$, p. 18.

171 NIETZSCHE, F., Nietzsche contre Wagner, §9, p. 129.

172 NIETZSCHE, F., Le cas Wagner, §2, p. 19.

173 Ibid. §7, p. 46.

174 Ibid. §2, p. 19.

175 Ibid. §7, p. 42.

176 NIETZSCHE, F., Nietzsche contre Wagner, §2, p. 101.
} 


\section{Música, o problema da saúde e da unidade}

Téages tinha tudo para se desviar da filosofia, mas o cuidado que tinha com a saúde (...) fez que não a deixasse. ${ }^{177}$

Neste capítulo farei uma breve incursão à República de Platão para mostrar como este filósofo já estava ocupado com a questão da saúde; porém, ao contrário de Nietzsche, Platão pensava a saúde por uma relação de identidade, isto é, enquanto estado que deve se conservar inalterado e que não tem na doença um elemento de sua constituição. Segundo a concepção platônica, diferentemente de Nietzsche, saúde e doença são estados que se excluem. Procurarei mostrar como para Platão a verdadeira saúde é a que pouco se altera e como a música, a "boa música" no seu entender, poderia ser um ótimo "remédio" desde que harmonizada e construída com a finalidade de ser um estímulo auxiliar na conservação e no repouso da saúde nela mesma, isto é, na manutenção de uma saúde em si.

Um problema percorre toda a República: como bem governar uma cidade? ${ }^{178}$ Segundo Sócrates, o fundamento de toda a cidade está no fato de não sermos auto-suficientes, mas carentes de muitas coisas (alimentação, moradia, roupas, etc.) ${ }^{179}$. E é a necessidade de se suprir tais carências que faz com que a diferença ${ }^{180}$ natural entre as pessoas - que faz de uns sapateiros, de outros tecelões, agricultores...- possa aparecer a nós como diferença benéfica. Pois, cada um realizando a tarefa que lhe é própria, todos poderiam contribuir uns com os outros por meio da troca ${ }^{181}$, de modo que as necessidades de todos os indivíduos da cidade pudessem ser satisfeitas.

Essa seria uma cidade autêntica, sadia. Mas, e quando a cidade até então sadia se incha, se "inflama", e passa a requisitar não mais apenas calçados, alimentos, moradias e roupas, mas também iguarias, perfumes, móveis, cortesãs, bolos, os “enfeites das mulheres", cores e formas? Apenas a arte do sapateiro, por exemplo, não mais seria suficiente para que a meta da cidade fosse atingida: alcançar, na medida do

\footnotetext{
177 PLATÃO. A república, Livro VI, p.242.

178 Ibid. Livro VII, p. 275.

179 Ibid. Livro II, p. 62.

180 Ibid. Livro II, p. 63.

181 Ibid. Livro II, p. 65.
} 
possível, a felicidade de todos os cidadãos ${ }^{182}$. Quando a cidade cresce e o luxo passa a fazer parte da vontade de seus cidadãos, fazendo surgir a arte da guerra e a arte das Musas, as dificuldades de uma cidade que se quer bem governada aumentam:

Aquela cidade, que era sadia, já não basta, mas a partir de então devemos aumentá-la e enchê-la com uma multidão de habitantes cuja presença na cidade não visa mais ao suprimento do necessário. ${ }^{183}$

Ao ser questionado a esse respeito por Gláucon, Sócrates responde que, a fim de evitar males à cidade, é preciso estabelecer um muito bom acordo acerca da função específica que caberia à cada cidadão, pois nenhum indivíduo pode realizar com perfeição duas tarefas ao mesmo tempo ${ }^{184}$. No entanto, na busca por tal acordo, Sócrates se depara com um problema: e as pessoas que, mesmo sedentas, não querem beber? ${ }^{185}$ Como poderia uma nau prosseguir bem sua viagem se permanentemente o piloto e os marujos estão em dissensão uns com os outros acerca da direção que devem tomar, matando-os uns aos outros para ver quem fica com a posse do timão? A nau, a cidade e o homem - ambos são acometidos por um problema que Platão tem por fundamental: o problema da unidade.

Não seria o avesso da unidade a desintegração, a não coesão, a dissolução no caos, na barbárie? A pergunta feita por Sócrates em relação à nau — em analogia à cidade - poderia ser pensada de igual maneira com relação ao homem: o que pode fazer uma cidade, uma nau, um homem para que continue sendo ela/ele mesma(o), senão conservar seus limites característicos?

- Então, disse eu, para nossos governantes, o limite ótimo será aquele que vai até onde eles devem fazer que a cidade cresça em tamanho, e, depois de se apropriarem de um território de extensão adequada a ela, abram mão de outros.

— Que limite? disse.

— Creio, disse eu, que é este aqui... "Crescer até o ponto em que, mesmo crescendo, possa ser uma só.” Além disso, não! ${ }^{186}$

No entanto, como conservar os limites de uma cidade quando esta não mais busca satisfazer somente suas necessidades fundamentais, mas adentra o reino do excesso, das necessidades supérfluas e do luxo? Como viver se não há acordo consigo mesmo? ${ }^{187}$

\footnotetext{
182 Ibid. Livro IV, p. 136.

183 Ibid. Livro II, p. 68.

184 Ibid. Livro II, p. 69.

185 Ibid. Livro IV, p. 164

186 Ibid. Livro IV, p. 140.

187 Ibid. Livro I, p. 40.
} 
A morte e a doença talvez fossem as imagens que melhor expressariam essa desintegração, esse estado alterado, essa pusilanimidade, essa perda de unidade e dos limites de si. É assim que Platão, por meio da boca de Sócrates, nos dá sua definição de saúde: sadio é o que pouco se altera ${ }^{188}$. Assim como o deus (essencialmente bom) não pode ser origem de males ${ }^{189}$; assim como a justiça não pode gerar injustiça; assim como o que é prejudicial tampouco pode ser ao mesmo tempo não-prejudicial ${ }^{190}$, Platão irá pensar a saúde a partir de uma relação de identidade, ou seja, assim como a saúde não pode gerar doença, também da doença não pode provir a saúde. Saúde e doença são, portanto, termos que se excluem naturalmente, pois aquele que é saudável não pode, por sua própria natureza, ser caracterizado com atributos que dizem respeito a um estado doentio: Ah! A virtude, pelo que se vê, seria como que saúde, beleza e boa disposição da alma, mas o vício, doença, feiúra e fraqueza. ${ }^{191}$

Em nosso dia-a-dia é comum vermos pessoas adjetivando alguém como "forte", "saudável", e em seguida pontuando: "ele nunca fica doente". Platão também toma a saúde como designando a estabilidade e a constância de algo que consegue se manter por muito tempo em sua forma característica, sua identidade, sem sofrer abalos, capaz de conservar-se em acordo consigo próprio de maneira a ter o domínio de si e não perecer. Se a justiça (virtude da alma ${ }^{192}$ ) se caracteriza por suscitar a concórdia, de modo que a injustiça se caracterizaria por suscitar a discórdia, o ódio e o conflito entre as partes ${ }^{193}$, a saúde não poderia designar outra coisa senão o estado daquele que possui a justa medida ${ }^{194}$ de si mesmo, preservando sua unidade característica e sendo senhor de si mesmo ${ }^{195}$.

- (...) Não seria a mais valente e sensata aquela [alma] a quem muitíssimo pouco uma impressão vinda do exterior perturbaria e alteraria? (...) E, (...) todas as coisas compostas, utensílios e edifícios, vestimentas, quando são bem trabalhadas e estão em bom estado, são as que se alteram muito pouco sob ação do tempo ou dos outros acidentes. ${ }^{196}$

Segundo Platão, é característica de uma natureza nobre, forte, permanecer em seu estado próprio sem sucumbir diante de estímulos que atuem contra seu ser, isto

\footnotetext{
188 Ibid. Livro II, p. 80.

189 Ibid. Livro II, p. 79.

190 Ibid. Livro II, p. 77.

191 Ibid. Livro IV, p. 172.

192 Ibid. Livro I, p. 43.

193 Ibid. Livro I, p. 38.

194 Ibid. Livro VI, p. 229.

195 Ibid. Livro IV, p. 151.

196 Ibid. Livro II, p. 80.
} 
é, contra a unidade/integridade de sua alma. Assim, por exemplo, não seria razoável que um deus perecesse ou que quisesse metamorfosear-se em outro ser qualquer, mas antes, já que "jamais afirmaremos que ao deus falta beleza ou virtude"197, seria muito mais razoável que ele não quisesse transformar-se, mas permanecer na forma que lhe é própria.

- Gerar saúde é dispor os elementos do corpo de modo que, de acordo com a natureza, entre eles haja uma relação de domínio e sujeição, mas gerar doença é, contrariando a natureza, um exercer o comando sobre outro e por ele ser comandado ${ }^{198}$

Mas como preservar a si mesmo, bem dispondo os elementos do corpo, quando se sabe que a razão representa apenas um "pequena parte"199 da alma, e que a parte maior da alma, a parte concupiscente, é insaciável por riquezas ${ }^{200}$ ? Caso queira permanecer saudável, mantendo a unidade e harmonia entre suas partes, a alma não pode apoiar-se "em algo que se mistura com a escuridão, com aquilo que vem a ser e perece" 201 , não pode apoiar-se na inconstância de algo que nunca se sacia e quer, por conta dessa insatisfação, sempre mais e mais e mais... É a sobriedade de uma razão sem sombras, não sujeita à escuridão, que deve comandar a parte concupiscível. Mas, para que isso aconteça, antes é preciso saber quais são os perigos dos quais ela, a alma, precisa defender-se. É preciso então que a razão tenha coragem, dirá Platão, e coragem é preservação. ${ }^{202}$

- Supõe (...) que coisa semelhante nós também fazíamos, ao fazer a seleção dos soldados e ao educá-los com a música e a ginástica, e que nada buscávamos senão persuadi-los a absorver da melhor forma as leis, (...) para que a opinião sobre os perigos (...) se mantivesse indelével graças à natureza e à educação adequada e para que a tintura que receberam não fosse lavada por esses sabões que são tão eficazes, (...) a dor, o medo e o desejo (...). Tal força e preservação constante da opinião reta e legítima sobre o que constitui perigos ou não eu chamo e considero coragem (...). ${ }^{203}$

A dor, o medo e o desejo. Ter força para preservar-se dos perigos que a dor, o medo e o desejo constituem. Segundo Sócrates, além de todo desejo ser desejo daquilo que é seu objeto natural, todos desejam o que é bom ${ }^{204}$. No entanto, Sócrates

\footnotetext{
197 Ibid. Livro II, p. 81.

198 Ibid. Livro IV, p. 172.

199 Ibid. Livro IV, p. 169.

200 Ibid. Livro IV, p. 168.

201 Ibid. Livro VI, p. 260.

202 Ibid. Livro IV, p. 149.

203 Ibid. Livro IV, p. 150.

204 Ibid. Livro IV, p. 162.
} 
sabia também que o homem é marcado por algo muito particular, a saber, que seus desejos podem muito bem desviar-se de sua finalidade natural, tal como o homem que, por exemplo, passa fome mas não quer comer. Sabia Platão da existência de uma dimensão irracional no homem, dimensão que, segundo ele, seria responsável por arrastar o homem à doença e à perda de si. Pois bem! disse eu. Que fique definido para nós que esses dois elementos estão na alma! ${ }^{205}$, isto é, o racional e o irracional.

Tal como o método dialético, que se utiliza de hipóteses apenas como degraus e pontos de apoio para ascender ao princípio de tudo ${ }^{206}$, retirando - com a ajuda do pensamento - a alma do pântano bárbaro e elevando para o alto seu olhar ${ }^{207}$, tal como uma melodia ascendente que parte do subterrâneo e ruma para o soler, Platão viu na música uma auxiliar, um remédio em potencial que auxiliaria na manutenção e conservação da saúde. Platão acreditava que a música poderia ser uma forte aliada da alma no sentido de poder auxiliá-la a manter o domínio de si ao expurgar os desvios, a doença e a ruína conseqüente da submissão aos desejos e às paixões. Comparando-se a uma escala musical que, interligando as notas múltiplas, torna-se una, o homem deve ser temperante e pleno de harmonia. ${ }^{209}$

—Ah! Quando já começam a brincar bem, por meio da música, as crianças acolhem dentro de si a boa norma, bem ao contrário do que ocorre com aqueles outros, e a boa norma as segue em tudo, vai crescendo com elas e restaurando o que antes estava em ruínas. ${ }^{210}$

Sensível ao caos, à desordem, à multiplicidade e instabilidade, sensível ao perigo iminente de ser arrastado em direções contrárias por conta da desmedida das paixões, Platão insiste sobre a necessidade de voltarmos nosso desejo para a verdade; é por conta do filósofo saber bem o perigo que a sedução, a mentira, a dor e o prazer representam para a estabilidade e a integridade de si (da nau, da cidade...) que Platão presume que os verdadeiros filósofos têm (deveriam ter) seus desejos voltados para o conhecimento da verdade ${ }^{211}$, isto é, para a contemplação e imitação de objetos imutáveis e bem ordenados ${ }^{212}$, pois desse modo não perderíamos nossos limites característicos, nossa unidade e coesão, assim como nos manteríamos

\footnotetext{
205 Ibid. Livro IV, p. 165.

206 Ibid. Livro VI, p. 263.

207 Ibid. Livro VI, p. 294.

208 Ibid. Livro VI, p. 292.

209 Ibid. Livro IV, p. 170.

210 Ibid. Livro IV, p. 142.

211 Ibid. Livro VI, p. 227.

212 Ibid. Livro VI, p. 247.
} 
senhor de nós mesmos. A razão, ter razão sobre si, é a condição para nos mantermos senhores de nós mesmos; ter razão sobre si é manter a primazia da justa medida entre as partes que constituem a alma, é manter a primazia da justiça (concórdia) sobre a injustiça (discórdia, conflito). Se tanto a dor quanto o prazer podem levar à perda de razão ${ }^{213}$, é preciso encontrarmos um meio de atingir um nível adequado de equilíbrio entre a tensão e o relaxamento ${ }^{214}$ entre esses dois registros, o intelecto e o concupiscível. Na música Platão via um meio de atingir a harmonização e equilíbrio entre essas partes da alma. O que é a música senão jogo sonoro que ora tensiona, ora relaxa? Acordes (conjunto de notas reunidas) de tensão, dissonantes, e acordes de repouso, consonantes, leves, relaxados, que parecem não querer sair do lugar. Um acorde de tensão quando quer descansar prepara, pede, um acorde de repouso. A música procede resolvendo tensões ou prolongando-as. Como uma música constituída inteiramente com acordes tensos ressoaria no ouvinte? Que reações ela estimularia? O acorde, por exemplo, constituído pelas notas que ressoam numa sirene, que disposições afetivas ele é capaz de suscitar? Saúde? Doença? Prazer? Medo? Alegria? Insegurança? Desprazer? Poder? Não poder? Justiça? Desconfiança? O que pode o pensamento sob a pressão desses sons?

Platão bem sabia do perigo da música. Isto é, sabia ele da força que a música comunica e exerce sobre as disposições de quem a escuta. Se uma cidade bem governada deve estar assentada na justiça, na justa medida dos elementos que a constituem, na temperança em detrimento da discórdia e do conflito, é então preciso afastar dela — assim como dos seus cidadãos — os excessos, o excesso de comida, de prazer, de ociosidade, de embriaguez, pois excedem a lei, transbordam os costumes tidos como necessários à manutenção da harmonia na pólis. É preciso afastar os excessos para que nem os indivíduos nem a cidade, devido à intemperança, caiam doentes. ${ }^{215}$ Querendo estimular seus cidadãos nesse sentido, de modo a se precaver contra um fracionamento e ruína da unidade constituída pela pólis, é preciso uma música que suscite a concórdia.

No entender de Platão, a boa música é uma música bem temperada, isto é, uma música que afasta de si o excesso, pois não quer exceder, não quer exceder a temperança, os bons limites, a justa medida, não quer criar estados incessantemente alterados e disformes, desmedidos, mas quer a saúde, isto é, quer manter a constância e soberania sobre si, e para isso deve querer pouco se alterar. Para manter uma boa índole é preciso domar os apetites e evitar o descomedimento; para uma boa índole é preciso uma boa música, isto é, uma harmonia (modos musicais que se

\footnotetext{
213 Ibid. Livro III, p. 112.

214 Ibid. Livro III, p. 124.

215 Ibid. Livro IV, p. 144.
} 
distinguem pelo arranjo dos intervalos dos sons ${ }^{216}$ ), ritmo e melodias equilibradas, bem temperadas, moderadas.

- Mas que a graça e a falta de graça derivam do bom ritmo e da ausência de ritmo, sobre isso é capaz de decidir?

— Como não?

- Mas o bom ritmo e a ausência de ritmo ocorrem quando, no primeiro caso, há semelhança com a boa elocução e, no outro, com a má, e o mesmo acontece com a boa e a má harmonia (...). ${ }^{217}$

A má postura e a ausência de ritmo e harmonia são irmãs da má elocução e da má índole, enquanto as qualidades opostas são irmãs e imitações do que é oposto a elas, o caráter do homem sábio e bom. ${ }^{218}$

O projeto de Platão tem na música um meio de impedir a intemperança, a baixeza, o vício, assim como o de bem educar, isto é, de fornecer por meio do que seria a boa música um bom direcionamento à saúde da pólis; a música deveria servir como referencial norteador dos bons hábitos dos cidadãos, tornando-os

capazes de buscar as pegadas do belo e do decoroso a fim de que, como se habitassem um lugar sadio, nossos jovens tirem proveito de tudo, de onde quer que seja, vindo das belas obras algo que lhes chegue aos olhos e ouvidos, como se fosse uma brisa que, vinda de boas regiões, a eles trouxesse saúde e levasse, já desde a infância, à semelhança, à amizade e à consonância com a bela palavra. ${ }^{219}$

Assim, por exemplo, evitando as harmonias chorosas, lânguidas e afeminadas $^{220}$, Platão acreditava que a harmonia que melhor deveria servir à função de guardião e guerreiro da pólis seriam as harmonias que melhor imitassem a voz dos homens sábios e corajosos. Assim, à cada função dos integrantes da pólis deveria ser justaposta uma devida harmonia musical, uma tal que fosse capaz de preservar, nortear e manter coesas as partes da alma de cada cidadão em sua respectiva função. Caso contrário, por conta da susceptibilidade dos homens à sedução auditiva, a música poderia suscitar intenso conflito e desajuste tanto às funções citadinas de cada cidadão quanto às partes desejantes e intelectuais de cada indivíduo, o que acarretaria o excesso, a instabilidade, a doença e a ruína da nau, da pólis e dos seus integrantes.

A partir de agora irei me deter à crítica feita por Nietzsche ao excesso, crítica ao excesso de sentimento, crítica elaborada por ele em Humano, demasiado humano,

\footnotetext{
216 Ibid. Livro III, p. 133.

217 Ibid. Livro III, p. 108.

218 Ibid. Livro III, p. 109.

219 Ibid. Livro III, p. 110.

${ }^{220}$ Ibid. Livro III, p. 106.
} 
obra que tem uma doutrina da saúde — que pode ser entendida também como uma disciplina da vontade ${ }^{221}$ — como seu mais forte ensinamento. Meu intento é fazer relacionar a crítica ao excesso feita por Platão às antípodas da crítica ao excesso feita por Nietzsche. Ao contrário da crítica ao excesso feita por Platão ${ }^{222}$, Nietzsche se apoiou numa razão que se mistura à escuridão ${ }^{223}$. Procurarei também demonstrar como Nietzsche viu, à semelhança do que fez Platão, a música como um auxiliar da saúde, mas à diferença de Platão, Nietzsche viu a música como auxiliar de uma saúde que ao invés de excluir a doença a inclui. Ao contrário de Platão, para quem a saúde não poderia gerar a doença, em Nietzsche da doença pode advir a saúde tanto quanto da saúde pode originar-se a doença ${ }^{224}$.

Ele [Nietzsche] condenava toda uma série de sensações e suas intensificações, não porque ele não as tivesse, ao contrário, porque ele as tinha e conhecia seus perigos. ${ }^{225}$

Tal como Platão, Nietzsche possuía grande sensibilidade para a desordem, para o vir a ser e perecer das coisas, para o perigo iminente da ruína e da não conservação de si. No entanto, isso não foi motivo que fizesse com que Nietzsche concebesse negativamente a guerra, isto é, que colocasse a paz e a felicidade acima da guerra ${ }^{226}$, e rejeitasse a desordem, o vir-a-ser e a inconstância, em nome de uma Verdade, de um Imutável, de uma Justa Medida, Deus... Já Platão, filósofo também sensível ao perigo iminente da desordem, afirmava que o bom filósofo deveria estar voltado para a Verdade, direcionando seus instintos sempre para o Imutável, a Justiça, pois desse modo se poderia alcançar uma saúde robusta e inalterável. Porém, se nosso tempo não mais crê em Deus ${ }^{227}$, Perfeito, Justo, Imutável - então, o que poderá dar sustentação e apoio à saúde? Sob qual referência poderemos fixá-la, de modo a torná-la sempre constante? Onde podemos nos apoiar, se já não encontramos mais uma base sólida que fundamente nosso repouso e que seja capaz de oferecer garantias de que nada irá alterar nossa unidade, que não pereceremos, que não perderemos o controle? Se não encontramos mais essa garantia, o que poderia evitar o debilitamento, o abalo da saúde, sua não conservação, seu desagregamento e divisão, seu vir a ser doença, enfermidade, estiolamento? E do mesmo modo, o que poderia evitar que a

\footnotetext{
221 Vide o primeiro capítulo.

222 PLATÃO. A República, Livro VI, p. 260.

223 NIETZSCHE, F., Humano, demasiado humano, §638, p. 272; O andarilho e sua sombra, p. 162.

224 RAYMOND, Didier, Nietzsche ou la grande santé, p. 139.

225 SALIS-MARSCHLINS, M. von, Philosoph und Edelmenssch. Ein Beitrag zur Charakteristik Friedrich Nietzsches. In GIACÓIA, O., Nietzsche como psicólogo, p. 75.

226 NIETZSCHE, F., Gaia Ciência, prólogo, §2, p. 11

227 NIETZSCHE, F., Humano, demasiado humano, §143, p. 104.
} 
doença pudesse vir a ser saúde? Como evitar as idas e vindas, as recaídas e ascensões? Que estatuto poderia adquirir a saúde num mundo que é inconstante, onde a estabilidade nunca pode se conservar ad eternum? Nesse mar de forças que vivem, que lutam incessantemente por prazer, onde podemos nos agarrar?

Se há alguma imortalidade no mundo em que vivemos, ela se encontra antes no próprio movimento, isto é, é a imortalidade do movimento ${ }^{228}$, movimento que nunca acaba, que sempre "incessa", inacabadamente, que está sempre "em se processando", que nunca se completa, sempre restando algo por mover. Assim é que, por exemplo, se queremos estimar o valor da infância, da idade adulta e da juventude, com estados em si - e não apenas como pontes e momentos de transição devemos ser capazes de estimá-los em seu inacabamento, pois em si as coisas são inacabadas. Somos capazes de nos alegrar com o inacabamento das coisas, com a incerteza que um poema pode trazer consigo ${ }^{229}$, somos capazes de amar na incompletude, isto é, de tomar a incompletude como estímulo?230

O que pode uma vida sob a pressão da incerteza? O que pode um pensamento incapaz de prescindir da certeza para pensar, para caminhar, quando não é capaz de saltar ${ }^{231}$ os abismos, os buracos sem fundo, que encontra pela frente? Um pensamento que não consegue prescindir da certeza - de um fundamento que possa servir-lhe como garantia de que não irá cair, errar o passo - pode ser capaz de caminhar? Onde ele se apóia? Alcançou tal pensamento a liberdade da razão? Segundo Nietzsche Quem alcançou em alguma medida a liberdade da razão, não pode se sentir mais que um andarilho sobre a Terra ${ }^{232}$; logo, apenas os pensamentos andados têm valor ${ }^{233}$, pois alcançaram a liberdade da razão e desacreditaram da intuição intelectual tanto quanto a substância da metafísica não existe, e se viram então errantes, impelidos a se deslocar sem visar uma meta final, sem um fundamento, sem um estofo racional que preenchesse e completasse o espaço deixado em aberto por suas incertezas, que lhes oferecesse guarida e proteção na caminhada em meio aos acontecimentos que nunca cessam, nunca acabam, incessantes e inacabados, nunca param de vir a ser.

O que é perfeito não teria vindo a ser. - Diante de tudo o que é perfeito, estamos acostumados a omitir a questão do vir a ser e desfrutar sua presença como se aquilo tivesse brotado magicamente do chão. ${ }^{234}$

\footnotetext{
228 Ibid. 208 , p. 129.

229 Ibid. $\$ 207$, p. 129.

230 Ibid. $\$ 199$, p. 126.

231 NIETZSCHE, F., A filosofia na era trágica dos gregos, p. 44 e p. 75.

232 NIETZSCHE, F., Humano, demasiado humano, §638, p. 271.

233 NIETZSCHE, F., Crepúsculo dos Ídolos, I, §34, p. 15.

234 NIETZSCHE, F., Humano, demasiado humano, §145, p. 107.
} 
Enquanto houver vir a ser, o que é perfeito não existe. Em meio ao vir a ser, o que é perfeito não poderia se efetivar, não teria vindo a ser. Nietzsche usa a palavra vollkomene para dizer "perfeito"; de voll, "pleno, cheio, repleto, completo, inteiro". ${ }^{235}$ Sendo pleno, absoluto, o que é perfeito não pode conter nenhuma privação, não pode conter negatividade, divisão, ausência nenhuma, não pode ter margens, início nem fim, pois isso suporia que o perfeito é limitado, mas, possuindo limites, o que é pleno deixaria de ser pleno por estar submetido a limitações, a coerções, a forças que ameaçam the destruir, lhe desestabilizar, provocando seu conflito, porém o que é perfeito não poder comportar luta, conflito, irresolução, inacabamento, parcialidade. Assim, o perfeito se opõe ao vir a ser na medida que em vindo a ser as coisas não são absolutas, perfeitas, porém inacabadas, incompletas, em permanente estado de conflito, cheias de borras, restos, resíduos...

No bar da experiência. - As pessoas que, por inata moderação, deixam todo copo pela metade, não querem admitir que tudo no mundo tem sua borra e seu resíduo. ${ }^{236}$

Existem aqueles para quem o copo deve estar sempre cheio, sempre com gotas a mais, pois no excesso eles vêem promessa de felicidade, assim como a parcialidade ofende-lhes a virilidade; há aqueles para quem o copo deve estar sempre vazio, pois o "cheio" thes soa um fardo pesado demais para o que podem, intolerável, insustentável, assim como no vazio eles se sentem mais livres, mais leves, aliviados, o vazio a eles faz pressentir a felicidade; há ainda aqueles para quem o copo deve sempre estar na exata metade, inteiramente cheio por um lado e inteiramente vazio por outro, assim eles crêem eliminar qualquer possibilidade de erro, de perda, alcançando assim o que seria o perfeito equilíbrio, perfeita felicidade. Ambos querem eliminar, cada qual a seu modo, o desconforto, as situações desfavoráveis à conservação de si, o que resta, sobra, escapa à sua soberania, à sua vaidade, ao seu prazer, à sua consciência, à sua eternidade, à sua vontade de saúde. Ambos querem, cada qual a seu modo, fixar uma justa medida, querem efetiva o pleno, o perfeito (Vollkomene), e para isso se vêem obrigados a omitir a questão do vir a ser, pois deste onde sempre transborda um resto, uma sobra, um resíduo a mais, uma borra, fazendo soçobrar o perfeito em inacabamento, incompleto, avesso de seu ideal. "Há coisas, acontecimentos e pessoas que não suportam ser tratados em pequena escala", assim como há aqueles que pequenos por natureza não toleram o engrandecimento ${ }^{237}$; seja lá como for, em que pesem as respectivas fixações de uns e outros, na

\footnotetext{
235 KELLER, A. Michaelis: dicionário escolar alemão, p. 300.

236 NIETZSCHE, F., Opiniões e sentenças, §389, p. 153.

237 NIETZSCHE, F., Humano, demasiado humano, §174, p.121.
} 
vida há que aprender a sair mais limpo de situações pouco limpas e, se preciso for, lavar-se também com água suja ${ }^{238}$, é preciso saber operar não apenas em meio às situações que se mostram mais favoráveis à expansão de nosso prazer, mas também em meio àquelas que nos são desfavoráveis, que nos coagem.

Mas se num mundo que é vir a ser não há espaço para o que é pleno e perfeito, o que Nietzsche poderia estar querendo dizer por "plenitude" na seguinte passagem: "Há um pessimismo da fortitude? Uma propensão intelectual para o duro, o horrendo, o mal, o problemático da existência, devido ao bem-estar, a uma transbordante saúde, a uma plenitude da existência?"239 Um bem-estar dentro do pessimismo; uma saúde que transborda rumo ao que é problemático na existência, uma plenitude que acolhe o horrendo, o mal, o duro, as condições desfavoráveis da existência... Pode a plenitude rimar com pessimismo? E por que ligar plenitude e pessimismo? Que relação existe aí? Interessante é notarmos que Nietzsche nessa passagem fala em tom de questionamento, de especulação, de suspeita acerca da existência de uma conciliação entre plenitude e pessimismo. Em Opiniões e Sentenças Nietzsche diz:

\begin{abstract}
Não importa como se morre - A maneira como uma pessoa pensa na morte, durante sua vida mais plena, no apogeu do seu vigor, é testemunha eloqüente daquilo que denominamos seu caráter; mas a hora da morte em si, sua atitude no leito de morte, quase não importa quanto a isso. ${ }^{240}$
\end{abstract}

Nesse caso, o que dá a medida de vigor, de plenitude, não é a ausência de limites, de coerção, mas justamente a atitude que se mantém face ao que oferece resistência à auto-conservação, ao que é problemático na existência, isto é, face ao que na existência é solidão, finitude, não conservação, morte, privação, horror, dor... Como se manter alegre em meio a muitos males ${ }^{241}$, em meio a um mínimo de vida, isto é, dor, abstinência ${ }^{242}$ ? Como extrair saúde da doença? O quanto a plenitude pode suportar de dor? O que é pleno quer a dor? A abstinência, privação, perda, é constituinte de um caráter forte, nobre, pleno? A doença é condição, meio, para a saúde? Para que rimar plenitude e morte, força e dor, saúde e doença?

Poderia ser o excesso um meio de superação da dor, um remédio que nos curasse do mínimo de vida a que a doença obriga ${ }^{243}$ ? Pode o excesso servir como ultrapassamento de um estado pessimista - isto é, estado que se caracteriza por

\footnotetext{
238 NIETZSCHE, F., Opiniões e sentenças, §82, p. 43.

239 NIETZSCHE, F., O nascimento da tragédia, prefácio, §1, p. 14.

240 NIETZSCHE, F., Opiniões e sentenças, §88, p. 44.

241 NIETZSCHE, F., Humano, demasiado humano, prólogo, §2, p. 08.

242 NIETZSCHE, F., Humano, demasiado humano II, prólogo, §5, p. 11.

243 NIETZSCHE, F., Humano, demasiado humano, §289, p. 178.
} 
afirmar que o desprazer é maior que o prazer $^{244}$ —, como forma de se alcançar uma certa superação, um estar além da sensação de privação e abstinência decorrente da perda da capacidade de órgãos que até então funcionavam bem? $\mathrm{O}$ excesso se liga à alegria? De modo semelhante a Platão, Nietzsche viu no excesso, na intemperança e imoderação, um sinal de degeneração, sintoma de decadência. E em Humano Demasiado Humano Nietzsche se serve diversas vezes do excesso para caracterizar a arte, a excessividade e imoderação como sendo característica do caráter ${ }^{245}$ artístico, a facilidade com que recorrem à imaginação para suavizar a desmedida das paixões, a dor e a miséria humana, extraindo assim prazer com a mentira ${ }^{246}$. - Porém, querendo ultrapassar toda coerção e resistência que a vida oferece, querendo eliminar todas as condições desfavoráveis, querendo eliminar todas as limitações, a arte acaba por rumar à dissolução de si mesma.

- Seriam a compaixão e o medo, como quer Aristóteles, realmente purgados pela tragédia, de modo que o espectador volta para casa mais frio e mais calmo?Deveriam as histórias de fantasmas tornar as pessoas menos medrosas e supersticiosas? Nos casos de alguns processos físicos, no ato do amor, por exemplo, é verdade que, com a satisfação de uma necessidade, há uma mitigação e uma temporária diminuição dos instintos. Mas o medo e a compaixão não são, neste sentido, necessidades de determinados órgãos que querem ser aliviadas. E com o tempo o próprio instinto é, mediante o exercício da satisfação, 'reforçado', apesar das mitigações periódicas. É possível que em todo caso individual a compaixão e o medo sejam atenuados e purgados pela tragédia: no entanto, pelo efeito trágico poderiam ser ampliados no conjunto, e Platão talvez tivesse razão em pensar que a tragédia nos torna mais medrosos e sentimentais, afinal. Então o próprio autor trágico adquirira necessariamente uma visão do mundo sombria e medrosa, e uma alma tenra, suscetível e lacrimosa; também estaria de acordo com Platão, se os autores trágicos, e as comunidades inteiras que com eles se deleitam especialmente, degeneram numa crescente falta de medida e de freio. - Mas que direito tem nossa época de responder a enorme questão acerca da influência moral da arte? Mesmo que tivéssemos a arte — onde está a influência, uma influência 'qualquer' da arte?247

Quais efeitos a arte pode gerar? A arte mitiga, atenua, sacia os instintos ou os torna ainda mais insaciáveis, redobrando-os, reforçando-os? Abranda, suaviza, amansa ou age antes como estímulo que retroalimenta suas disposições, numa ânsia cada vez mais crescente? As cenas do teatro trágico, por exemplo, levariam as pessoas a voltarem mais calmas para suas casas, tornadas momentaneamente menos suscetíveis à compaixão, à dor e ao sombrio do mundo, ou as tornaria ainda mais medrosas, mais compassivas, mais suscetíveis e sentimentais do que antes?

\footnotetext{
244 NIETZSCHE, F., Humano, demasiado humano, §28, p. 35.

245 NIETZSCHE, F., Opiniões e sentenças, §88, p. 44.

246 NIETZSCHE, F., Humano, demasiado humano, §154, p. 110.

247 Ibid. §212, p. 131.
} 
Os órgãos querem saciar-se. Os instintos querem a satisfação; precisam aliviar-se, diminuir a tensão que os atormenta e os impulsiona ao prazer, ao poder. O desprazer em demasia, a tensão em excesso, arruína qualquer corpo, leva-o ao colapso, à dissolução. Viver requer prazer; uma vida não pode viver inteiramente no desprazer, sem contrabalanços e doses de prazer, sem contraponto algum à tensão, sem doses de relaxamento; uma vida é incapaz de se limitar ao mal-estar, a uma dor cada vez mais crescente e volumosa, assim como um acorde que se desenvolva em pura dissonância, que num crescendo desenfreado vai se tornando cada vez mais e mais tenso se torna ao fim barulho, ruído, estrondo. Até onde se estende o nosso sistema nervoso, nós nos protegemos contra a dor (...). Sem prazer não há vida; a luta pelo prazer é a luta pela vida; e por "prazer" entenda-se: sentimento do próprio poder, conservação de nosso bem-estar, de nossa saúde. ${ }^{248}$

$\mathrm{O}$ amor como uma necessidade que, satisfeita em seus instintos, temporariamente pode ser mitigada, diminuída a intensidade e exigência de seus impulsos; tal é a imagem que Nietzsche nos fornece nessa passagem. No entanto, afirma ele, pode ocorrer em alguns casos de, mediante a recorrência da satisfação - efeito a que a arte muitas vezes tem como objetivo e pelo qual procura facilitar o acesso ao invés dos instintos serem abrandados, aliviados, acabam por se avolumarem ainda mais, se tornarem mais insaciados e menos capazes de reter, de esperar, "numa crescente falta de medida e de freio". Em seguida, Nietzsche relaciona a falta de medida, a intemperança dos instintos, à influência que a moral tem na arte, passando então a interrogar ironicamente se nessa arte desmedida haveria alguma arte, utilizando o mesmo termo "arte" em acepções distintas, contrapostas.

A moral para Nietzsche é um modo de valorar que é hostil à vida; com seus padrões absolutos, fixos, a moral quer obter prazer, mas não suporta ter de lutar para poder ao final obter senão um prazer que é efêmero, submetido ao vir a ser, ao transitório e inconstante; a moral não tolera o conflito mediante o qual a vida acontece e por isso se vê levada a fixar valores que são transcendentes a toda guerra, independentes do vir a ser, de modo a colocar assim o prazer acima da guerra, isto é, tomando o prazer como uma negação da dimensão conflitual da vida, ansiando assim por uma vida eterna de prazer, ao invés de afirmar um prazer que não seja negação da guerra, que não seja negação da vida, um prazer que se dê na guerra, e não além, acima da guerra. A moral quer uma vida que seja prazer, e não - como define Nietzsche em Humano Demasiado Humano — uma vida que seja "luta por prazer".

Nesse sentido, a moral é um anseio pelo repouso ${ }^{249}$, anseio pelo qual ela se vê levada a ter de extirpar tudo o que pode suscitar conflito e assim obstaculizar o aces-

\footnotetext{
248 Ibid. $§ 104$, p. 75.

249 NIETZSCHE, F., O nascimento da tragédia, prefácio, §5, p. 19.
} 
so à sua pretendia felicidade eterna, se vê levada a ter de extirpar toda ilusão, erro e sensualidade. Mas desse modo a moral concebe a felicidade negativamente, isto é, concebe a felicidade como negação da vida, quando nela, na moral, tudo impele para o sol sossego, brandura. Querendo a vitalidade a qualquer preço, a moral acaba por dar mostras de sua vontade de morte, de fim, sintomas de sua vontade de declínio, de seu cansaço, desânimo, de sua vitalidade empobrecida, arruinada, de sua doença ${ }^{250}$.

Mas, como? Como a vontade de eternidade, como uma vida que fosse pleno prazer, que quer a plena felicidade, como quer a moral, onde não houvesse erro, mentira, dor, ilusão, uma vida plena de paz, repouso, com uma paz robusta, com uma saúde robusta, plena de luz, em que tudo fosse luz, certeza, claridade, onde não houvesse fresta na qual a sombra pudesse ameaçar entrar... - Como nessa busca por plenitude, por uma vida que seja somente prazer e felicidade, como nessa busca pode estar expressa uma vontade de fim, de declínio, uma vontade de negação? Como o desejo de uma vitalidade a qualquer preço pode ser antes o sintoma de uma vitalidade empobrecida, de uma vontade de nada, vontade de fim, de ausência de si? No anseio por uma saúde robusta Nietzsche localiza uma doença, uma vontade de saúde que nasce de uma doença.

- Poderia o mais pleno ser o reverso de si, sinal invertido de um desânimo, fraqueza, de uma vontade de nada, de uma vontade de declinar? A vontade de eternidade, de absolutização do vigor, absolutização da saúde, absolutização do poder, do prazer, seria antes uma máscara, o disfarce de uma vida que se vê em perigo e que diante desse perigo degenera num sonho metafísico de eternidade? Uma vida sem erro ${ }^{251}$, que não tolera a dor e sua falta de sentido ${ }^{252}$, para quem a vida carece de razão de maneira constante ${ }^{253}$, a quem toda injustiça ${ }^{254}$, ilusão ${ }^{255}$, mentira ${ }^{256} \mathrm{e}$ ilogicidade ${ }^{257}$ são tidos como objeção à vida e por isso devem ser reformados, extirpados inteiramente em detrimento de uma vida plenamente favorável... os que assim desejam estão doentes e querem plenamente negar a vida em seu vir a ser indiferente ao ideal demasiadamente humano de auto-conservação, estão cansados, extenuados, não dispõem mais de forças curativas, plásticas, não mais são capazes de tomar as condições desfavoráveis como estímulo, não conseguem

\footnotetext{
250 Ibid. prefácio ,§5, p. 19.

251 NIETZSCHE, F., Humano, demasiado humano, §33, p. 39.

252 NIETZSCHE, F., Genealogia da moral, III, §28, p. 149.

253 NIETZSCHE, F., O nascimento da tragédia, prefácio, §5, p. 20.

254 NIETZSCHE, F., Humano, demasiado humano, §32, p. 37.

255 NIETZSCHE, F., Humano, demasiado humano, prólogo, §1, p. 08.

256 NIETZSCHE, F., Humano, demasiado humano, §34, p. 39.

257 Ibid. $\$ 31$, p. 37.
} 
mais caminhar frente à menor resistência que a vida oferece à realização de seus anseios, não toleram a possibilidade de ter de refrear suas paixões pois querem todo limite exceder em satisfação e felicidade, em completude e estabilidade, repouso. No entanto, seu aparente vigor é a máscara de uma hostilidade à vida, de um anseio pelo fim, fim da luta; seu aparente vigor e saúde é seu ideal — sob o qual se encontra sua degeneração, sua fraqueza, debilitamento, doença - assim como a verdade pode nascer da mentira, e sem nos darmos conta podemos estar a apreciar belos quadros de cabeça pra baixo, em que os cumes da paisagem podem conter grandes abismos, o céu ser o espelho d'água de um rio, o crepúsculo ser a aurora, animais solares serem toupeiras... O sonho de imortalidade na Nona Sinfonia de Beethoven, assim como a melodia infinita e a obsessão pela salvação nos temas das óperas de Wagner são para Nietzsche exemplos de decadência na arte moderna na medida em que pretendem abolir do mundo todo o sofrimento, toda coação, todos limites, toda convenção, na expectativa de com isso alcançar um mundo pleno de condições favoráveis à expansão do seu prazer. Ambos, Wagner e Beethoven, se utilizaram da música como meio de seduzir seus ouvintes e os fazer se sentir mais aliviados da falta de sentido para o seu sofrimento, fazendo-os acreditar pelo menos por uns instantes numa existência Além de todos os limites, de toda finitude. Ambos procuraram criar atmosferas livres de todo incômodo e perturbação - tal como fazem os lógicos que, crendo na realidade dos conceitos e nomes das coisas, criam realidades que não têm qualquer correspondência com o mundo real ${ }^{258}$, dando assim livre curso a uma necessidade metafísica ${ }^{259}$, aos sentimentos que querem excluir toda impertubabilidade e exigem vitalidade e satisfação ao todo custo. Em ambos reina um excesso de sentimento. ${ }^{260}$

Durante muito tempo o sentimento cabia à alçada da religião, era nesta onde os homens na maior parte das vezes podiam manifestar mais livremente seus anseios, seus medos, suas crenças pessoais, sua fé... Mas o Iluminismo, ao sobrepor a razão à fé, acabou abalando os fundamentos em que a religião se apoiava para construir seus argumentos; a ascensão do ideal de razão na Europa "abalou os dogmas da religião e instalou uma radical desconfiança: assim, expulso da esfera religiosa pelo Iluminismo, o sentimento se lança na arte." ${ }^{261}$ Como conseqüência da perda de terreno que a religião sofre, o excesso de sentimento a que a religião dava vazão acaba se lançando na arte. A arte desse modo herda o excesso doentio de sentimento da religião, excesso que acreditava carregar o céu dentro de si e que para isso tinha

\footnotetext{
258 Ibid. $§ 11$, p. 21.

259 Ibid. $§ 153$, p. 110.

260 Ibid. $\$ 219$, p. 135.

261 Ibid. $§ 150$, p. 109.
} 
de negar a medida, os limites do homem e da terra, numa invenção psicológica que, pretendendo salvar o homem, acabou por torná-lo não nobre, por corrompê-lo, embriagá-lo, despedaçá-lo, barbarizá-1o. ${ }^{262}$

$\mathrm{O}$ excesso de sentimento que assim se lança na arte que salvar o homem, tamponar a falta de sentido que ele vê na vida, ainda que esse alívio só se efetive momentaneamente. Mas, querendo tornar a vida mais leve, querendo aliviar a vida dos homens, os artistas "desviam o olhar do árduo presente":

Certamente há coisas desfavoráveis a dizer sobre seus meios de aliviar a vida: eles acalmam e curam apenas provisoriamente, apenas no instante; e até mesmo impedem que os homens trabalhem por uma real melhoria de suas condições, ao suprimir e purgar paliativamente a paixão dos insatisfeitos, dos que impelem à ação. ${ }^{263}$

Querendo facilitar a vida, a arte ecoa a influência da moral e sua ânsia de repouso ao suprimir o que impele à ação, ao trabalho: as paixões insatisfeitas, o árduo presente. Assim a arte cria uma ilusão de satisfação, de perfeição, mente um poder que não tem, cria demasiadamente, e desse modo impede que vejamos os reais motivos que nos coage a agir, ao omitir os reais problemas impede a conquista de nossa grandeza, de nossa saúde. A arte dessa maneira age como o dentista que, para aliviar a dor de dente, extrai o dente desde a raiz e se envaidece com o fato de ter feito cessar a dor de seu paciente e com isso ter fornecido-lhe, com a cessação da dor, o que acredita ser uma saúde. Mas que preço terá de pagar seu paciente caso queira a "saúde" não apenas dos dentes, mas de toda sua pele, de toda sua pessoa - terá ele de extrair toda sua sensualidade? Eliminar toda sensualidade é o preço que se paga caso se deseje fazer a dor cessar completamente? Chegaríamos com isso a uma saúde? ou à doença? Excluindo toda dor nossa vitalidade se torna mais crescente ou declinante? O que seria de uma boca que não tem dor de dentes assim como não possui dente algum? O excesso grosseiro que quer eliminar toda e qualquer condição desfavorável, toda doença, todo mínimo de vida, terminará tal qual uma boca que, para não sentir dor, arrancou todos os dentes e com isso se tornou incapaz de mastigar, de triturar, de extrair prazer e energia da luta com alimentos duros e capazes de ofender sua saúde.

- Há um tédio das mentes mais refinadas e cultivadas, para quem o melhor que o mundo oferece tornou-se insípido: habituados a comer alimentos seletos, cada vez mais seletos, e a desgostar-se com os mais grosseiros, correm o perigo de morrer de fome - pois existe muito pouco do melhor, e às vezes ele se tornou inacessível ou duro demais, de sorte que nem mesmo bons dentes conseguem mordê-lo. ${ }^{264}$

\footnotetext{
262 Ibid. $§ 114$, p. 88.

263 Ibid. $\$ 148$, p. 108.

264 NIETZSCHE, F., Opiniões e sentenças, §369, p. 149.
} 
De que serve expandir a consciência se nossa boca não mais é capaz de mastigar, de saborear o doce e o amargo dos alimentos? De que serve uma hiper consciência se não podemos mais digerir, se esquecemos nossos pés? Somos inteiramente resultado do que pensamos? Uma consciência expandida pode remover montanhas? Pode a consciência remover as condições desfavoráveis que o corpo enfrenta? Há aqueles que, querendo ser todo prazer, consciência, tudo poder, extirpam os instintos, a sexualidade e o desejo afim de evitar as desagradáveis consequências que daí podem advir à supremacia da consciência, mas já não admiramos os dentistas que extraem os dentes para que eles não doam mais... ${ }^{265}$ Contra essa tendência é preciso educadores que, ao invés de extirparem os impulsos instintivos, nos ensinem a resistir a um estímulo, a não reagirmos imediatamente, a espiritualizar nossos desejos, isto é, a dar-lhes direção, selecionando-os, cultivando-os, resistindo ora aqui ora ali, melhor conduzindo-os. ${ }^{266}$

Querendo uma vitalidade a qualquer preço e buscando suprimir a não realização imediata da vontade de prazer, rejeitando a realidade histórica do mundo e fazendo realidades perfeitas brotarem como que magicamente do chão, a arte manifesta uma moralidade mais fraca do que a do pensador. Procurando negar a desimportância e mesmo indiferença do mundo em relação ao homem, os artistas criam fantasmas - o que não existiria para físicos e filósofos ${ }^{267}$ — recorrendo à facilidade com que procedem pela imaginação a fim de suavizar a miséria humana ${ }^{268}$. "Porém a moderna negação da morte não explica a amplitude da mentira e do desejo de não saber a verdade"269:

- No que toca ao conhecimento das verdades, o artista tem uma moralidade mais fraca do que o pensador; ele não quer absolutamente ser privado das brilhantes e significativas interpretações da vida, e se guarda contra métodos e resultados sóbrios e simples. Aparentemente luta pela superior dignidade e importância do ser humano; na verdade, não deseja abrir mão dos pressupostos mais eficazes para a sua arte, ou seja, o fantástico, mítico, incerto, extremo, o sentido para o simbólico, a superestimação da pessoa, a crença em algo miraculoso no gênio: considera o prosseguimento de seu modo de criar mais importante que a devoção científica à verdade em qualquer forma, por mais simplesmente que ela se manifeste. ${ }^{270}$

Somos inteiramente resultado do que criamos? Nossa capacidade de criar pode remover montanhas? A posição de Nietzsche nesse momento é a de que o artista não

\footnotetext{
265 NIETZSCHE, F., Crepúsculo dos idolos, V, §1, p. 33.

266 Ibid. VIII, §6, p, 69.

267 NIETZSCHE, F., Humano, demasiado humano, §160, p. 113.

268 Ibid. $\$ 154$, p. 110.

269 SONTAG, S. Doença como metáfora, p.14.

270 NIETZSCHE, F., Humano, demasiado humano I, §146, p. 107.
} 
quer se sentir privado, e para isso não quer abrir mão de sua própria interpretação da vida, não quer abrir mão de suas fantasias, de sua mitologia, de seus símbolos, não quer abrir mão da superestima que tem pelo humano, não quer abrir mão da crença no gênio enquanto ser milagroso, ser capaz de tudo criar, de fazer realidades perfeitas como que brotarem magicamente do chão; o artista não quer abrir mão da sua criação assim como de suas criaturas, de suas criações, não quer submetê-las ao crivo do pensamento, da razão, do conhecimento, não quer saber, não quer saber da verdade de sua criação, quer apenas criar suas verdades. Não refreando sua imaginação, suas paixões, sua vontade de criar, o artista não correrá o risco de se sentir privado de sua soberania sobre a vida e da crença em seu poder revolucionário, isto é, em sua capacidade de ultrapassar todos os limites e obstáculos onde a vida lhe oferece resistência. No entanto, a posição de Nietzsche é que o desejo incessante de criar é vulgar ${ }^{271}$, barbariza o homem, arruína sua unidade, sua saúde; a ausência de seletividade e de medida com seus instintos leva-o à dissolução de si mesmo; querendo tornar as coisas fáceis demais para si mesmo, o artista adoece.

\begin{abstract}
A doença é a resposta, cada vez que queremos duvidar do direito à nossa tarefa que começamos a tornar as coisas fáceis demais para nós. (...) As facilidades que nos damos, eis o que temos de pagar mais duramente! E, se depois queremos retornar á saúde, não nos resta escolha: temos de assumir uma carga mais pesada do que a que levávamos antes... ${ }^{272}$
\end{abstract}

Contra o adoecimento da arte, contra o efeito moralizante na arte, arte que cria não com o intuito de ser um estimulante para a vida ${ }^{273}$, mas com o intuito de tapear esta, - "as alucinações têm com frequência o valor de remédios que em si são venenos" $" 274$, tal como os benefícios que podemos extrair "de uma filosofia, de uma religião, nada provam quanto à sua verdade", assim como "a felicidade que um louco desfruta com sua idéia fixa nada prova quanto à racionalidade dessa idéia"275 — contra isso que considera ser uma falta de medida, uma regressão intelectual, um excesso de sentimento, Nietzsche irá, em Humano Demasiado Humano, recorrer estrategicamente à ciência enquanto medida capaz de contrabalançar a atitude desenfreada da arte.

O artista sabe que sua obra só tem efeito pleno quando suscita a crença numa improvisação, numa miraculosa instantaneidade da gênese; e assim ele ajuda essa ilusão e introduz na arte, no começo da criação, os elementos de inquietação entusiástica,

\footnotetext{
271 Ibid. $\$ 210$, p. 130.

272 NIETZSCHE, F., Humano, demasiado humano II, prólogo, §4, p. 11.

273 NIETZSCHE, F., Crepúsculo dos ídolos, IX, §4, p. 65.

274 NIETZSCHE, F., Humano, demasiado humano, §164, p. 118.

275 Ibid. §161, p. 114.
} 
de desordem que tateia às cegas, de sonho atento, como artifícios enganosos para dispor a alma do espectador ou ouvinte de forma que ela creia no brotar repentino do perfeito. - Está forra de dúvida que a ciência da arte deve se opor firmemente a essa ilusão e apontar as falsas conclusões e maus costumes do intelecto, que o fazem cair nas malhas do artista. ${ }^{276}$

O artista age como um sedutor, a beleza é sua malha, e a crença no brotar repentino do perfeito, na improvisação instantânea da felicidade é seu efeito. A beleza age por meio dele como um artifício enganoso que turva o intelecto e que é capaz de prender a atenção do espectador a um sonho, ao entusiasmo com a gênese instantânea do belo. A dose de vaidade que carregamos conosco ao voltar nossos olhos e ouvidos para o belo se compraz com nossa ânsia de ser belos e felizes. Ao ver a beleza ansiamos "ser belos: imaginamos que haveria muita felicidade ligada a isso. — Mas isto é um erro."277 A vaidade nos faz suscetíveis à sedução do artista, tal como ocorre nas promessas de salvação que as óperas de Wagner sugerem ao ouvinte, onde o alívio experimentado pelos heróis na hora de sua salvação serve como consolo à nossa própria vaidade, isto é, à nossa vontade de causar a impressão de superioridade, vontade de tornar pública a superioridade que nos falta, superioridade que desejamos mas não temos. ${ }^{278}$

Buscando momentaneamente nos libertar da coerção da necessidade ${ }^{279}$, facilitando o alívio de nossos instintos e querendo purgar nossas paixões, a arte pode nos tornar sentimentalmente desenfreados, incapazes de reter nossos impulsos, incapazes de esperar, afoitos por uma satisfação instantânea e constante, de maneira que o menor obstáculo, a menor imperfeição, qualquer mínimo de vida, de doença, de condições desfavoráveis, se torna logo negado em vista de um além, se torna longo uma ponte para uma transcendência, para um mundo "melhor", para um mundo em que nossa vaidade, nosso ideal, possa se expandir mais facilmente, onde possamos nos ver pairando "felizes" sobre a Terra. A arte desse modo procede fazendo semblante de vigor, como que por involuntários desvios, inconscientemente empurrando para a "vitalidade" a qualquer custo, para o sol, sossego, brandura ${ }^{280}$; mas com um remédio que sonha com a absolutização da saúde, a arte expressa uma vontade de negação da vida, negação do vir a ser, uma ânsia por repouso, e justamente pelos "benefícios" que ela dispõe à vaidade humana, a arte se torna incapaz de figurar "nas primeiras filas da ilustração e da progressiva virilização da humanidade."281

\footnotetext{
276 Ibid. §145, p. 107.

277 Ibid. $§ 149$, p. 109.

278 Ibid. $\S 170$, p. 120.

279 Ibid. \$213., p. 131.

280 NIETZSCHE. Gaia ciência, prólogo, §2, p. 10.

281 NIETZSCHE. Humano, demasiado humano, §147, p. 108.
} 
A posição de Nietzsche, em Humano Demasiado Humano, com relação à arte é que ela possui uma influência regressiva para a humanidade, ela infantiliza a humanidade pois quer romper todos os limites para poder dar vazão ao seu excesso de sentimento, porém desse modo ela, a arte, ruma à barbárie; a veneração pela instantaneidade e pela exigência de satisfação a qualquer custo faz com que o artista comprometa sua capacidade intelectual, faz como que ele perca seu centro de gravidade, sua unidade de estilo, sua sobriedade, sua força plástica, sua força seletiva, seu vigor, sua capacidade de poder resistir, de suportar o ócio que pode advir da doença, de poder reter e acumular suas energias de modo a poder dar direção aos seus instintos, às suas necessidades; sendo incapaz de reter, o artista se torna também incapaz de construir ${ }^{282}$, de elaborar, de pensar, de tomar os estados debilitados e enfermos como meio para sua cura, para um grande saúde. Porém, querendo negar toda coerção, o que a arte alcança é uma dispersão dos instintos, um abrandamento da consciência, que pode até em ceras ocasiões causar uma impressão de saúde, de vigor, mas que não passa de uma máscara de sua doença, de um disfarce de sua decadência. Fazendo surgir "apenas uma vida aparente", como em sonhos onde mortos queridos podem retornar à vida ${ }^{283}$, a arte regride a outros tempos, infantiliza os homens e assim não contribui pra que trabalhem por uma real melhoria de suas condições.

Cada vez mais o artista venera emoções repentinas, acredita em deuses e demônios, põe alma na natureza, odeia a ciência, adquire um ânimo instável como os indivíduos da Antiguidade e requer uma subversão de todas as relações que não sejam favoráveis à arte, e isso com a veemência e insensatez de uma criança. Ora, em si o artista já é um ser retardado, pois permanece no jogo que é próprio da juventude e da infância: a isto se junta o fato de ele aos poucos ser regredido a outros tempos ${ }^{284}$

"A fim de viver resolutamente na completude e na plenitude"285, a arte idealiza condições inteiramente favoráveis à sua conservação, idealiza todos os eventos da vida como meio de aliviá-la ${ }^{286}$, se consola metafisicamente ao invés de rir do absurdo ${ }^{287}$, rir do fato de que "no conjunto a humanidade não tem objetivo nenhum, e por isso, considerando todo o seu percurso, o homem não pode nela encontrar consolo e apoio, mas sim desespero" 288 , rir do fato de que "toda vida humana está profundamente embebida

\footnotetext{
282 Ibid. $\$ 218$, p. 135.

283 Ibid. $\S 147$, p. 108.

284 Ibid. $§ 159$, p. 113.

285 NIETZSCHE, F., O nascimento da tragédia, prefácio §7, p. 22.

286 NIETZSCHE, F., Humano, demasiado humano, §279, p. 174.

287 NIETZSCHE, F., Humano, demasiado humano, §213, p. 131.

288 Ibid. $\$ 33$, p. 38.
} 
na inverdade"289, rir do fato de que nada no humano pode existir sem um grão de irracionalidade ${ }^{290}$, de extrair prazer do absurdo de uma vida que não visa nada além da luta por prazer, por poder, e que para isso requer firmeza na ação, isto é, comedimento e censura de uma avidez desenfreada. ${ }^{291}$ Tal idealismo é enganador, apressado, não tem amizade pelo lento, satisfaz apressadamente seus sentimentos à custa de uma mentira.

- Também não devemos nos deixar tiranizar pelo mais belo prazer: o de elevar as coisas ao plano ideal, senão, um dia a verdade se afasta de nós com estas palavras feias: "Rematado mentiroso, que tenho eu a ver contigo?" 292

Mas uma questão se coloca: como pode Nietzsche aqui criticar a produção de mentira e ilusões pela arte se é ele também quem critica o caráter fixo da verdade?! pois, segundo próprio Nietzsche, a vida não é uma grandeza fixa, de modo que não pode haver um cálculo exato sobre a vida ${ }^{293}$, quem pensa mais profundamente sabe que está sempre errado, não importa como proceda e julgue ${ }^{294}$, não há uma Justiça ${ }^{295}$, não há uma substância que norteie a vida, não há deus, a vida não poderia não ser andarilha, injusta, de onde surge a necessidade da produção de ilusão, a vida requer ilusão ${ }^{296}$, requer sombra tanto quanto luz.

Platão também criticou os artistas por produzirem falsas interpretações e assim corromper a unidade da pólis, provocando sua ruína, sua dissolução. Não ascendendo dos instintos à razão, os artistas, para Platão, se mantinham vulneráveis à instabilidade das paixões, metamorfoseando-se como só a mentira é capaz, instavelmente como quem se encontra enfermo, ao contrário da estabilidade que caracteriza a verdade, a saúde e a justiça. Segundo Platão, a verdade, tal qual a saúde, não pode ser instável, contraditória, intemperante, dissonante, descompassada, má ritmada, sinuosa, mas deve comportar-se de acordo com sua essência, isto é, deve ser necessariamente estável, plenamente idêntica a si mesma, reta, justa, justa medida...

A doença para Platão se manifesta na incapacidade para fazer algo ${ }^{297}$, a doença impede alguém de fazer o que se quer ${ }^{298}$ e de apenas poder agir involuntaria-

\footnotetext{
289 Ibid. §34, p. 39.

290 Ibid. $\$ 450$, p. 219.

291 Ibid. §464, p. 255.

292 NIETZSCHE, F., Humano, demasiado humano II, §345, p. 143.

293 NIETZSCHE, F., Humano, demasiado humano, §364, p. 192.

294 Ibid. $\$ 518$, p. 243.

295 Ibid. $\$ 32$, p. 37.

296 NIETZSCHE, F., Humano, demasiado humano, prólogo, §1, p. 08.

297 PLATÃO, Hipias menor, p. 62.

298 Ibid, p. 65.
} 
mente, despossuído da consciência sobre si, seja por uma debilidade física ou por uma debilidade intelectual, por ignorância ${ }^{299}$. Esses fatores - ignorância, incapacidade e involuntarismo - corrompem a unidade e geram instabilidade, degeneração, isto é, fragmentação. Em Hípias Menor, em meio a um acesso de febre, Sócrates chega à conclusão de que aqueles que mentem voluntariamente são superiores àqueles que mentem involuntariamente, pois os primeiro agem deliberadamente, têm consciência de que estão mentindo, enquanto os últimos agem sem ter posse de si mesmos, agem ingenuamente. Ao afirmar isso, que os que cometem faltas e provocam ilusões voluntariamente são superiores, mais sábios que aqueles que o fazem involuntariamente, Sócrates sente um desconforto consigo mesmo, sente-se à deriva, parece não querer dar crédito à conclusão que chegou ${ }^{300}$ - o problema consiste em saber como alguém que tem real posse de si pode agir em sentido contrário à verdade e assim, mentindo voluntariamente, ser considerado alguém sábio? Um sábio que mente, voluntariamente? Como alguém que sabe da verdade de sua mentira pode preferir a mentira à verdade? Como alguém poderia em sã consciência querer errar, querer mentir, querer produzir o falso? Agindo assim não se estaria enganando-se a si próprio voluntariamente, lucidamente buscando a perda de si mesmo, como que criando estradas de se perder ${ }^{301}$ ? Mas como alguém em real posse de si e da verdade pode produzir falsas visões? pois da verdade não poderia surgir a mentira, abismos, erros e imperfeições, ilusões, mas somente o caminho reto, claro e justo, em completo acordo com a essência da verdade, tal como da justa medida não pode nascer a intemperança.

Dizer que aquele que sabe mentir, que mente porque, sabendo da verdade, quer mentir e assim o faz voluntariamente, em total posse de si, com total autonomia e acordo consigo, é um contra-senso já que a mentira gera desacordo, está fundada no próprio desacordo, põe à deriva, gera instabilidade, o que se opõe frontalmente ao sentido de verdade tal qual entende Platão, isto é, enquanto plena identidade, plena justiça e estabilidade, pleno acordo consigo. Daí o desconforto que tem Sócrates diante da conclusão a que chega. A boa música, segundo Platão, serviria para transpor esse estado de deriva, para tornar a dissonância uma consonância, para superar esse estado de desconforto, de desacordo, de desarmonia, de injustiça, de intemperança, estados esses que têm na produção do falso sua base, sua condição própria.

Semelhantemente a Platão nesse sentido, Nietzsche também se utilizou do voluntário e do involuntário como critérios para ora louvar a ilusão ora para criticá-la, com a diferença de que em Nietzsche a ação voluntária não estaria referida nem

\footnotetext{
299 Ibid. p. 67.

300 Ibid. pg.92.

301 Música "Sabiá", da autoria de Tom Jobim e Chico Buarque.
} 
fundamentada na Justiça, não pode se guiar pela crença no pleno acordo, na imutabilidade das Idéias. Os gregos nesse sentido são bons exemplos de onde se serviu Nietzsche para situar sua posição quanto à ação voluntária/involuntária, pois ao mesmo tempo em que os gregos eram desmedidamente apaixonados possuíam também "um intelecto extremamente agudo" que não lhes deixava se iludir quanto ao amargor e crueldade da vida; a dimensão por assim dizer trágica da vida lhes era tão sensível que recorrer à imaginação era a eles necessário para suavizar a miséria humana, para abrandar a agudeza do seu intelecto e a desmedida de suas paixões, pois "sabiam que apenas através da arte a própria miséria pode se tornar deleite". Agindo assim, eles criavam voluntariamente: "Eles não se iludem, mas deliberadamente cercam e embelezam a vida com mentiras" ${ }^{\text {302 }}$. Relembrando a posição de Sócrates acerca da superioridade daquele que mente voluntariamente, no Hípias Menor, podemos dizer aqui que, para Nietzsche, os gregos mentiam voluntariamente. Eles sabiam que estavam a criar ilusões para com isso embelezar a vida, pois em si mesma a vida não é bela, deleite, prazer; saborear a vida na sua imediatez, instantaneidade e crueza pode significar a ruína de toda tentativa de auto-satisfação humana, ruína da conservação de si, esquartejamento de toda unidade numa multiplicidade de pontos moventes e, conseqüentemente, o advento de uma ausência de si. Os gregos sabiam que estavam a dissimular - tal como todo homem é incapaz de viver o instante em si, de viver circunscrito apenas ao presente e de maneira inteiramente não histórica, todo passado esquecendo, tal como os animais são capazes de esquecer já que são incapazes de dissimular (ou simular) ${ }^{303}$; o homem, ao contrário dos outros animais, não pode prescindir de todo e qualquer artifício assim como nunca pôde prescindir do intelecto como meio para atingir sua auto-conservação e superar sua fragilidade, seu menor vigor, já que não pode empreender uma luta pela existência com chifres. Por conta dessa espécie de fragilidade, no homem essa arte da dissimulação atinge se cume. ${ }^{304}$

No entanto, o deleite que os gregos obtiveram com a mentira voluntária alcançou um nível tão grande de prazer que o prazer de fabular acabou atormentando-os como um castigo: "na vida cotidiana tornou-se difícil para eles livrar-se da mentira e da ilusão, como todos os povos e poetas, que têm igual prazer na mentira e não experimentam nisso nenhuma culpa." ${ }^{305}$ Dessa maneira, os gregos acabaram se excedendo na sua luta por prazer, em busca da satisfação, da satisfação dos seus instintos, e não querendo recuar da sua exigência por satisfação contínua terminaram debilitando-se, sem medida, desenfreados, adoeceram... Se tornando incapazes

\footnotetext{
302 NIETZSCHE, F., Humano, demasiado humano, §154, p. 110.

303 NIETZSCHE, F., Considérations inactuelles II, §1, p. 95.

304 NIETZSCHE, F., Sobre verdade e mentira no sentido extra-moral, p. 27.

305 NIETZSCHE, F., Humano, demasiado humano, §154, p. 111.
} 
de esperar se tornaram incapazes de extrair os benefícios do ócio e da privação de satisfação a que a doença obriga; não souberam se afirmar em meio à doença, em meio às condições desfavoráveis, não tomaram a doença como estímulo para sua saúde e se debilitaram; frente à doença não se fizeram saudáveis, mas se tornaram doentes. - A mentira até então exercida voluntariamente pelos gregos, de maneira deliberada, com permissão e aval de sua consciência, de sua razão, assim tornou-se neles instinto, e passaram então a mentir involuntariamente, isto é, independentemente de sua consciência, da razão, agindo de maneira irracional ${ }^{306}$. Com isso, passando a mentir involuntariamente, os gregos responderam de maneira inversa ao modo como o suicida responde ao problema da não satisfação dos seus instintos, da sua vaidade ferida e da incapacidade de aguardar sua convalescença: enquanto o suicida celebra com sua morte voluntária a vitória de sua razão sobre a nature$\mathrm{za}^{307}$, sobre o prolongamento do tempo, os gregos, ao darem livre vazão aos seus instintos, às suas fantasias, teriam - ao menos no que diz respeito a essa passagem específica de Nietzsche - manifestado a derrota de sua razão em detrimento da ascenção do involuntário, da desrazão nas suas ações. O trágico muitas vezes se manifesta pela incapacidade de esperar.

Saber esperar é algo tão difícil, que os maiores escritores não desdenharam fazer disso um tema de suas criações. Assim fizeram Shakespeare em Otelo e Sófocles em Ajax; se tivesse deixado o sentimento esfriar por um dia apenas, seu suicídio já não lhe terá parecido necessário, como indica a fala do oráculo; provavelmente teria zombado das terríveis insinuações da vaidade ferida e teria dito a si mesmo: quem, no meu lugar, já não tomou uma ovelha por um herói?será uma coisa tão monstruosa? Pelo contrário, é algo humano e comum; dessa forma Ajax poderia se consolar. A paixão não quer esperar; o trágico na vida de grandes homens está, freqüentemente, não no seu conflito com a época e a baixeza de seus semelhantes, mas na sua incapacidade de adiar de adiar por um ou dói anos a sua obra; eles não sabem esperar. ${ }^{308}$

A crítica de Nietzsche à produção de ilusão pela arte não se justifica exclusivamente pelo fato de mentirem, mas de - a exemplo de como fizeram os gregos quando deixaram de mentir voluntariamente - criar ilusões voluntariamente e se esquecer disso, isto é, de tomar suas ilusões como se tivessem sido formadas involuntariamente, como se fossem verdades involuntárias, verdades naturais, independentes do artifício de sua razão criadora, e passando assim a querer seduzir seus espectadores a acreditarem na instantaneidade da criação de mundos perfeitos, na sua genialidade miraculosa, na capacidade instantânea que os artistas teriam de satisfazer suas paixões, como se os paraísos criados por eles não fossem o resultado

\footnotetext{
306 NIETZSCHE, F., O andarilho e sua sombra, §185, p. 247.

307 NIETZSCHE, F., Humano, demasiado humano, §80, p. 62.

308 Ibid. §61, p. 57.
} 
de um laborioso esforço cultivado que soube reter por alguns momentos seus impulsos, canalizando suas energias. Mas tais paraísos são artificiais, embora queiram nos causar a impressão de serem reais. Essa espécie de auto-comiseração e vaidade da arte que age como os maus poetas que querendo fazer tudo parecer harmonioso não têm um pensamento forte e em tudo querem encontrar uma rima ${ }^{309}$, que quer ocultar o árduo e lento trabalho que se requer para a construção de uma obra, para o cultivo de si, impede que se trabalhe para uma real conquista da saúde, impede a conquista de uma grandeza nas ações, dificulta o desenvolvimento de forças plásticas, de um vigor plástico, curativo, isto é, aquele capaz de tomar a doença, o imperfeito, as borras e resíduos do incompleto, como estímulo para a conquista da nossa felicidade, do nosso prazer, da nossa saúde. "Quem quiser colher felicidade e satisfação na vida, que evite sempre a cultura superior."”10

Os artistas têm interessa em que se creia nas intuições repentinas, nas chamadas inspirações, como se a ideia da obra de arte, do poema, o pensamento fundamental de uma filosofia, caísse do céu como um raio de graça. Na verdade, a fantasia do bom artista ou do pensador produz continuamente, sejam coisas boas, medíocres ou ruins, mas o seu julgamento, altamente aguçado e exercitado, rejeita, seleciona, combina; como vemos hoje nas anotações de Beethoven, que aos poucos juntou as mais esplêndidas melodias e de certo modo as retirou de múltiplos esboços. Quem separa menos rigorosamente e confia de bom grado na memória imitativa pode se tornar, em certas condições, um grande improvisador; mas a improvisação artística se encontra muito abaixo do pensamento artístico selecionado com seriedade e empenho. Todos os grandes foram trabalhadores, incansáveis não apenas no inventar, mas também no rejeitar, eleger, remodelar e ordenar. ${ }^{311}$

Embora Beethoven, segundo Nietzsche, tenha criado atmosferas em que se pode sentir pairando acima da Terra, como num sonho metafísico de imortalida$\mathrm{de}^{312}$, inspirando-nos a crença em realidades perfeitas que teriam nascido independentemente de toda realidade histórica, de todo vir a ser, introduzindo ilusões que nos predispõem a acreditar no brotar repentino, na instantaneidade da gênese ${ }^{313}$, malgrado esses artifícios utilizados por ele na sua música, fora ele um incansável trabalhador, organizador, e para isso teve de espiritualizar — isto é, selecionar, rejeitar, combinar, conduzir - as notas até que conseguisse erguer as belas melodias de que foi capaz. Grandeza é algo que se conquista. Nietzsche, em Humano Demasiado Humano, criticou o excesso dos artistas, seu sentimentalismo desenfreado,

\footnotetext{
309 Ibid. $\S 610$, p. 258.

310 Ibid. $\$ 277$, p. 174.

311 Ibid. §155, p. 111

312 Ibid. $\$ 153$, p. 110.

313 Ibid. $§ 145$, p. 107.
} 
justamente na medida em que eles não eram verdadeiramente artistas; sobreexcitados, fingindo serem homens excessivamente apaixonados, eles querem causar a impressão de serem artistas quando na verdade não o são ${ }^{314}$, pois dando vazão a um excesso de sentimento se mostram incapazes de dar forma, de arquitetar e construir, modelar, espiritualizar, dar direção, canalizar seus anseios e instintos.

$\mathrm{O}$ excesso de sentimento, a avidez pela vitalidade a qualquer preço pode se apresentar em duas vertentes diferentes, dependendo de onde cada artista depositar maior esperança de satisfação e de realização do seu interesse, de sua vaidade: enquanto alguns artistas esperam encontrar maior satisfação pela via do baixo sensual, outros depositam maior expectativa em alcançá-la pela via do alto sensual ${ }^{315}$. Tomando o caso da música como exemplo, os primeiros artistas investem no ruído, no barulho, no originalmente hostil aos ouvidos, enquanto os segundos investem numa hiperintelectualização dos sons, de modo que por esta via todos os sons devem se encontrar acometidos por um significado, todos devem significar, simbolizar algo à razão, e tudo que até então era ruído vazio ${ }^{316}$ se torna preenchido por uma alta carga de simbolização. Por ambos caminhos chegamos à barbárie; chegamos à barbárie por esse caminho, tão seguramente quanto por qualquer outro ${ }^{317}$. Tais eram as duas correntes que Nietzsche via na evolução musical da Alemanha:

(...) de um lado um grupo de dez mil pessoas, com exigências cada vez mais elevadas e delicadas, e cada vez mais atentas para o "isso significa", e de outro lado a imensa maioria, que a cada ano se tornou mais incapaz de entender o significativo também na forma da feiúra sensorial, e por isso aprende a buscar na música o feio e repugnante em si, isto é, o baixamente sensual, com satisfação cada vez maior. ${ }^{318}$

Uma característica que marca bem a modernidade, para Nietzsche, é o aceleramento da vida ${ }^{319}$. Por conta da enxurrada de experiências e informações, da enorme soma de sentimentos e conhecimentos que recebeu, o homem moderno se viu à beira da loucura e do perigo que a superexcitação das forças nervosas e intelectuais pode acarretar: "as classes cultas dos países europeus estão mesmo cabalmente neuróticas" ${ }^{320}$. Diante do excesso de informações, o homem moderno se viu levado a ter de ampliar seus horizontes afim de que pudesse processar tal excesso, mas assim ele próprio se tornou excessivo, intranqüilo, acelerado, e quis fazer do próprio

\footnotetext{
314 Ibid. $\$ 211$, p. 130.

315 Ibid. $\$ 217$, p. 134.

316 Ibid. $\$ 216$, p. 133.

317 Ibid. $\$ 217$, p. 134

318 Ibid. $\$ 217$, p. 134

319 Ibid. $\$ 282$, p. 175.

320 Ibid. $§ 244$, p. 155.
} 
excesso sua verdade final, sua coisa-em-si, pois precisava fixar uma verdade aonde pudesse se agarrar em meio a essa torrente de emoções e sentimentos, mesmo que essa verdade fosse localizada no próprio excesso, na própria torrente, pois ele mal conseguira acreditar nesse evento demasiado grande que já começava a lançar suas primeiras sombras sobre a Europa que foi o fato de que não há coisa-em-si, de que "Deus está morto" 321 . Entre a morte da coisa-em-si, morte de Deus, por um lado, e a enxurrada de novas informações e experiências pelas quais passava a ter acesso, por outro, o homem moderno se tornou inquieto e, por falta de tranqüilidade, se viu lançado numa nova barbárie ${ }^{322}$. A abundância de sentimentos profundamente excitados, a barbárie dos instintos, logo se tornou uma questão a ser enfrentada, se fazendo ouvir tanto na literatura, na religião, na filosofia, quanto na música moderna. ${ }^{323}$

Se Platão, sensível que foi ao problema da barbárie dos instintos, do perigo do desgoverno das paixões, acreditou resolver o problema fornecendo uma coisa-em-si, uma essência, uma justa e perfeita medida na qual a música deveria se fiar, de modo a assim poder se tornar inteiramente voluntária, racional, consciente, isso já não é mais possível de ser feito com Nietzsche, para quem "em si, música alguma é profunda ou significativa, ela não fala da "vontade" ou da "coisa em si"; isso o intelecto só pôde imaginar numa época que havia conquistado toda a esfera da vida interior para o simbolismo musical. Foi o próprio intelecto que introduziu tal significação no som". ${ }^{324}$ Desse modo a música na modernidade encontra-se em errância, sem saber ao certo que caminhos deve trilhar, onde depositar sua "verdade", onde encontrar sua vitalidade, pois todos os caminhos e critérios são logo posto sob suspeita; mas, seja como for, ela quer extirpar a errância, negá-la, seja pelo alto sensual, seja pelo baixo sensual, seja ainda pela "música absoluta", tal como Wagner fizera. Esse parece ser o caso mais interessante na música moderna: se ela se encontra em errância, quer no entanto a qualquer custo eliminar todo erro, toda doença, toda dor, toda coerção, e para isso quer ser revolucionária ${ }^{325}$, quer uma melodia que seja infinita, contínua, que pareça flutuar e nadar ao invés de dançar e marchar, e com isso ser capaz de causar no ouvinte a impressão de possuir uma saúde robusta, uma saúde que não sofre abalos e que vive num estado de plenitude milagrosa, independente de todo contraponto - mas assim a música inviabiliza uma verdadeira cura, "exatamente como a arte médica só pôde

\footnotetext{
321 NIETZSCHE. Gaia ciência, §343, p. 233.

322 NIETZSCHE. Humano, demasiado humano, §285, p. 177.

323 Ibid. §244, p. 155.

324 Ibid. §215, p. 132.

325 Ibid. $\S 221$, p. 136.
} 
florescer quando acabou a crença em curas milagrosas" ${ }^{326}$, possibilitando que alguns homens pudessem tomar a grande desordem e condições desfavoráveis como meios para se tornarem mais fecundos, e a doença como contraponto necessário para a conquista de uma nova saúde, de uma grande saúde, que se deu ao preço de recaídas e períodos de convalescença.

Mas, ao contrário do que seria de se esperar de uma grande arte, a música moderna, com seu excesso de sentimento e falta de medida, intenciona romper com toda uniformidade de tempo e espaço, zombar de todos os limites, de toda finitude, almejando assim uma melodia infinita, uma música que seja absoluta, um ritmo que alterne imoderadamente entre um compasso de sete tempos, de cinco, de três, de dois... Assim, buscando romper com toda medida, a música moderna dá mostras de uma decadência do espírito, de sua ausência de vigor, ausência de virilidade, de força, a ausência de uma superior plasticidade, em suma, dá mostras de sua essência demasiado feminina. ${ }^{327}$

Contra essa tendência demasiado feminina na arte, Nietzsche vai se utilizar do espírito da ciência. Na medida em que o espírito científico sabe que o dom de ter muitas idéias deve ser refreado ${ }^{328}$ tanto quanto a abundância de sentimentos, o excesso de forças nervosas e intelectuais que beiram a neurose e a loucura, arrefecendo assim a fé em verdades finais e definitivas, o homem científico é apenas a continuação do homem artístico ${ }^{329}$, do verdadeiro artista, o homem científico é um grande artista.

\footnotetext{
326 Ibid. §242, p. 153.

327 NIETZSCHE, F., Opiniões e sentenças, §134, p. 66.

328 NIETZSCHE, F., Humano, demasiado humano, §264, p. 167.

329 Ibid. §222, p. 141.
} 


\section{Da vontade de prazer}

Querer o prazer não é um erro, mas uma necessidade. A posição de Nietzsche em Humano, demasiado Humano é a de que sem prazer não há vida, chegando mesmo a identificar vida à luta por prazer ${ }^{330}$. Tal ponto de vista é fundamental para Nietzsche no sentido de poder afirmar sua tese da completa irresponsabilidade $e$ inocência das ações humanas, já que tudo no mundo é necessidade ${ }^{331}$, isto é, necessidade de prazer. O que Nietzsche pretende ao argumentar em prol da inocência é contrapor esta ao autodesprezo humano, ao nojo do homem pelo homem.

É principalmente ao falar da concepção cristã do homem que Nietzsche irá explanar a questão do nojo do homem por si mesmo. Procurando se afastar de uma explicação mitológica do fenômeno religioso, Nietzsche irá ousar, como ele mesmo diz, fornecer-lhe uma explicação psicológica onde o que está em jogo é o incômodo que a consciência do homem sente entre, por um lado, sua incapacidade de experimentar a perfeição divina, e, por outro lado, sua incapacidade de se furtar ao desejo. O ser humano percebe em si próprio um pendor que lhe parece imutável para ações tidas na hierarquia social como sendo de um valor muito baixo, e gostaria sobremaneira de experimentar as ações tidas como sendo aquelas de tipo mais elevado, isto é, "gostaria de se sentir pleno da boa consciência que deve acompanhar um modo de pensar desinteressado! Mas infelizmente permanece no desejo" ${ }^{332}$, no interesse, na perspectiva de poder obter a satisfação de seus impulsos pessoais, no pendor para a realização de ações tidas como más e incapaz de realizar ações inteiramente altruístas como só Deus é capaz, isto é, de "viver na contínua consciência de um modo de pensar desinteressado"333. O descontentamento por não satisfazer a vontade de tornar-se pleno como Deus soma-se ao descontentamento por suas "más" inclinações, por permanecer no desejo, fazendo surgir no homem um "profundo mal-estar, juntamente com a busca por um médico que possa suprimir este" 334 . Caso o homem não tivesse Deus como critério de medida e avaliação de si mesmo, caso se compa-

\footnotetext{
330 NIETZSCHE, F., Humano, demasiado humano, §104, p. 75.

331 Ibid. $\$ 107$, p. 76.

332 Ibid. §132, p. 94.

333 Ibid. $\$ 132$, p. 94.

334 Ibid. $§ 132$, p. 94.
} 
rasse com outros seres humanos, o mal-estar não seria sentido com tanta amargura, pois "não teria razão de ficar descontente consigo mesmo, carregaria apenas uma parte do fardo geral da insatisfação e imperfeição humana"335. Em seguida, Deus começa a aparecer à imaginação humana como justiça punidora, como juiz e carrasco a açoitar o ser humano por sua permanência no desejo e por não agir conforme a perfeição divina, isto é, conforme uma consciência contínua e impessoal, inteiramente desinteressada. Tal pensamento angustia o homem, que passa a sentir desprezo por si mesmo, a se sentir culpado por seus instintos, e vislumbra na extirpação de seus desejos a supressão do seu mal-estar, de suas imperfeições, erros e insatisfações. $\mathrm{Na}$ supressão do seu desejo, dos seus impulsos, dos seus instintos, o homem vislumbra a cura do seu mal-estar e a conquista de uma plenitude, de um estado ausente de erros e imperfeições, ausente de vaidade, assim como o alcance de uma maior proximidade com a onipotência impessoal e desinteressada que caracteriza Deus.

Mas o homem poderia fazer algo "que fosse sem referência a ele, ou seja, sem uma necessidade (que sempre teria seu fundamento numa necessidade pessoal)?"336 Segundo Nietzsche, o homem teria caído nesse estado de autodesprezo por sua crença na existência da impessoalidade, no prazer em si, como se fosse possível obtermos "prazer com uma coisa" sem vaidade alguma, quando na realidade o que há é "o prazer consigo mesmo mediante uma coisa" ${ }^{" 337}$. Tais erros de razão foram erros de comparação; querendo tomar Deus como critério de medida e espelho da natureza humana, o sentimento de autodesprezo do homem parecia justificar-se, o nojo de si se tornava algo razoável. No entanto, na base desse ser "perfeito" esteve sempre a imperfeição da imaginação e dos juízos humanos ${ }^{338}$; Deus é uma medida, uma "perfeição", uma referência, um ideal, uma obra humana que é sintoma da vontade do homem de eliminar e ultrapassar todos os limites, toda privação, toda dor, todo desprazer, toda doença, toda condição desfavorável, tudo o que lhe coage e resiste ao seu poder Deus é a medida de um ideal, ideal de satisfação que é o ideal da religião, esta satisfaz o ânimo do indivíduo em tempos de perda, de privação, de terror, de desconfiança ${ }^{339}$. No entanto, para alcançar um estado ausente de dor, o homem se viu levado a ter também de extirpar toda sua sensibilidade, de negar o seu desejo, sua vontade de prazer, teve de negar tudo o que lhe causa momentos de satisfação e bem-estar consigo, teve de negar a si mesmo. Porém, não podemos abolir a nós mesmos ${ }^{340}$.

\footnotetext{
335 Ibid. $\$ 132$, p. 94.

336 Ibid. $\$ 133$, p. 95.

337 Ibid. $\$ 501$, p. 41.

338 Ibid. §133, p. 94.

339 Ibid. \$472, p. 227.

340 Ibid. $\S 452$, p. 220.
} 
Ao cristão que comparara a sua natureza com a de Deus sucede o mesmo que ao Dom Quixote, que subestima sua valentia porque tem na cabeça os feitos maravilhosos dos heróis de romances de cavalaria: o metro com que em ambos os casos se mede pertence ao reino das fábulas. ${ }^{341}$

Um ser capaz apenas de ações altruístas é uma fábula, jamais um homem fez algo apenas para os outros e sem qualquer motivo pessoal ${ }^{342}$. A absoluta impessoalidade que caracteriza Deus é uma invenção da imaginação humana; um ser inteiramente altruísta é impossível, impossível tanto quanto um Deus que fosse todo amor não seria capaz de realizar uma única ação altruísta, pois a fim de poder fazer algo pelos outros é preciso antes fazer muitíssimo para si mesmo, condição que um ser completamente desinvestido de si próprio, que não quer nada para si mas apenas para os outros, não poderia satisfazer ${ }^{343}$.

Há que se lembrar que, segundo Nietzsche, o cristianismo nasceu para aliviar o coração, oprimindo inicialmente para depois aliviar ${ }^{344}$. Após descrever a crença na impessoalidade e na consciência continuamente desinteressada de Deus como fonte para o autodesprezo humano, Nietzsche irá apontar um segundo momento presente no mecanismo psicológico do cristianismo, momento que se caracteriza pela ascensão a uma nova autoestima, aonde o homem é acometido pela percepção de que o estado de desprezo que nutria por si mesmo, de remorso e de desprazer não persiste mais, "o prazer consigo mesmo, o bem-estar com a própria força" passa a prevalecer, "o homem sente que de novo ama a si mesmo" ${ }^{345}$. No entanto, ele percebe com muito assombro esse sentimento de prazer que experimenta consigo, essa nova auto-estima lhe parece inacreditável, algo imerecido que só poderia advir por meio de uma força externa, da perfeita bondade e misericórdia divina. Entre a opressão e o alívio, entre o autodesprezo e o prazer que teria de advir de uma força exterior, de Deus, em ambos os casos o que vige é uma negação, uma negação de si mesmo, abnegação, ápice da moral ${ }^{346}$, pressuposto para tornar-se santo ${ }^{347}$. Nega-se a si mesmo primeiramente através do nojo e autodesprezo por não alcançar a contínua satisfação que adviria por uma consciência plenamente desinteressada; num segundo momento a negação se dá quando, se sentindo culpado por sua permanência no desejo, atribui todo prazer e bem-estar que sente a uma força exterior que lhe concede caridosamente essa

\footnotetext{
341 Ibid. $\$ 133$, p. 96.

342 Ibid. $\$ 133$, p. 95.

343 Ibid. $\$ 133$, p. 95.

344 Ibid. $\$ 119$, p. 90.

345 Ibid. $\$ 134$, p. 96.

346 Ibid. §138, p. 99.

347 Ibid. $§ 140$, p. 100.
} 
"graça" em algumas ocasiões. Em ambos os casos o real prazer diz respeito apenas a Deus, enquanto ao homem resta o desprazer e a permanência no desejo, isto é, em prazeres "menores", inconstantes, imorais, vis. O autodesprezo é a negação de que o homem possa experimentar o prazer a partir de si mesmo, devendo assim se manter restrito ao sofrimento, à dor, enquanto o prazer como tal, verdadeiro, constante e contínuo, a plena satisfação, só cabe a Deus. O autodesprazador manifesta uma concepção negativa do prazer, isto é, põe o prazer acima da guerra; para ele, obter prazer só é possível a partir da negação de si mesmo; apenas aonde ele já não encontra a si próprio, aonde se encontra ausente, pode existir prazer, enquanto a si próprio restam apenas os desejos vis, a imperfeição, o desprazer.

Contra esse sentimento de culpa, contra essa concepção negativa do prazer que está sempre a negar o prazer a si mesmo, Nietzsche irá afirmar a inocência e irresponsabilidade da vida, isto é, a inocência da luta pelo poder, da luta por prazer. Segundo a concepção de inocência de Nietzsche, o homem, como todos os demais seres, não são inocentes por um "sem querer" ou por um não-saber, os homens são inocentes por querer, por quererem o prazer e para tanto lutarem, chegando mesmo a cometer "maldades" para se satisfazer. Os homens são inocentes por não poderem agir contrariamente a uma necessidade, contra uma necessidade da própria vida; os homens não poderiam não querer o prazer, não poderiam não querer o poder, não poderiam não querer o que consideram útil para a sua autoconservação.

O processo químico e a luta dos elementos, a dor do doente que anseia pela cura, possuem tanto mérito quanto os embates psíquicos e as crises em que somos arrastados para lá e para cá por motivos diversos, até enfim nos decidirmos pelo mais forte - como se diz (na verdade, até o motivo mais forte decidir acerca de nós). Mas todos esses motivos, por mais elevados que sejam os nomes que lhes damos, brotaram das mesmas raízes que acreditamos conter os maus venenos; entre as boas e as más ações não há uma diferença de espécie, mas de grau, quando muito. Boas ações são más ações sublimadas; más ações são boas ações embrutecidas, bestificadas. O desejo único de autofruição do indivíduo (junto com o medo de perdê-la) satisfaz-se em todas as circunstâncias, aja o ser humano como possa, isto é, como tenha de agir: em atos de vaidade, de vingança, prazer, utilidade, maldade, astúcia, ou em atos de sacrifício, de compaixão, de conhecimento. Os graus da capacidade de julgamento decidem o rumo em que alguém é levado por esse desejo. ${ }^{348}$

A posição de Nietzsche em Humano, demasiado Humano é a de que todas as ações humanas, sejam elas consideradas boas ou más, provêm da busca do prazer, do desejo de obter a satisfação consigo, de afastar a dor e conservar o próprio bem-estar, e sendo assim não há por que culpabilizar e responsabilizar os indivíduos, pois todos agem em busca da autoconservação necessariamente, e não por livre-arbítrio. O que

348 Ibid. $\$ 107$, p. 76. 
irá variar é o grau intelectual com que cada indivíduo conduz e avalia seus impulsos, conquanto os impulsos neles mesmos não devem serem vistos como algo reprovável e extirpável, e isso na medida em que a própria vida é impulsão em vista do prazer, impulsão em vista do que é útil para a conservação do próprio bem-estar.

O indivíduo quer para si o prazer ou quer afastar o desprazer; a questão é sempre, em qualquer sentido, a autoconservação. Sócrates e Platão estão certos: o que quer que o homem faça, ele sempre faz o bem, isto é: o que lhe parece bom (útil) segundo o grau de seu intelecto, segundo a eventual medida de sua racionalidade. ${ }^{349}$

Tantos as ações tidas por boas quanto as tidas por más têm por objetivo o prazer consigo ${ }^{350}$. O homem que pratica ações consideradas nocivas não pode ser considerado responsável por seus impulsos, pois age conforme uma necessidade que é própria da vida em geral, apenas podendo ser repudiado segundo as regras impostas por um Estado que visa conservar o bem-estar do maior número de pessoas possível, mas não do ponto de vista da natureza, pois é da natureza do sistema nervoso nos proteger contra a dor, e em todo dano considerado intencional o que está em jogo é a própria existência de cada indivíduo, isto é, "a conservação de nosso bem-estar"351. Ao se autodesprezar por seus instintos considerados vis, o homem supõe nele uma vontade livre, uma vontade capaz de operar nele independentemente desses instintos, e nisso está o erro ${ }^{352}$, pois o homem, assim como a vida, é necessariamente vontade de prazer, anseio de cura, busca de proteção contra o desprazer ${ }^{353}$, busca da autofruição de si.

Em si mesmo o prazer não é nem bom nem mau; de onde viria a determinação de que, para ter prazer consigo, não se deveria suscitar o desprazer alheio? Unicamente do ponto de vista da utilidade, ou seja, considerando as consequências, o desprazer eventual, quando o prejudicado ou o Estado que o representa leva a esperar punição e vingança: apenas isso, originalmente, pode ter fornecido o fundamento para negar a si mesmo tais ações. - Assim como a maldade não visa ao sofrimento alheio em si, como já disse, também a compaixão não tem por objetivo o prazer do outro. ${ }^{354}$

Mas, se todas as ações, sejam elas consideradas boas ou más, são motivadas pelo impulso de autoconservação, isto é, pelo "propósito individual de buscar o prazer e evitar o desprazer" 355 , por que haveria Nietzsche de criticar a extrema

\footnotetext{
349 Ibid. $\$ 102$, p. 73.

350 Ibid. $§ 103$, p. 73.

351 Ibid. §104, p. 75.

352 Ibid. $\$ 102$, p. 72.

353 Ibid. §102, p. 73.

354 Ibid. \$103, p. 73.

355 Ibid. §99, p. 99.
} 
volúpia que a música moderna desperta em seus ouvintes como sendo uma doença, um abalo e solapamento da saúde ${ }^{356}$ ? Como ele poderia criticar, por exemplo, a manifestação excessiva de poder e o desejo de plenitude presente no socialismo ${ }^{357}$, o alívio gerado pelas religiões e suas opiniões agradáveis ${ }^{358}$ que sempre agem em vista do benefício e do prazer do homem, de sua redenção ${ }^{359}$ ? Como poderia criticar o fato da ciência moderna ter por meta uma espécie de eterna beatitude, isto é, o mínimo de dor e a vida mais longa possível ${ }^{360}$ ? Por que criticá-los justamente pelo fato de buscarem evitar o desprazer e almejarem uma constância do prazer? A religião, o socialismo, a ciência moderna, a música moderna... não estariam antes agindo conforme uma necessidade da própria vida, isto é, não estariam senão buscando seu bem-estar, sua autoconservação?

Contra o autodesprezo e a negação de si mesmo que caracterizam a moral, a grande saúde requer a afirmação de si mesmo. Gostaria de chamar a atenção nesse ponto, a grande saúde não diz de um incessante oscilar entre a saúde e a doença, mas de uma oscilação entre a saúde e a doença que é sempre capaz de retornar à saúde, capaz de reunir, acumular e direcionar suas forças no sentido de poder restabelecer a saúde. O centro de gravidade da grande saúde não é a doença, mas a saúde, uma tal que é capaz de tomar a doença e os estados desfavoráveis como estímulo, como meio de retorno a si, como meio de retorno à instável estabilidade ${ }^{361}$, pois "uma vez tendo se encontrado, é preciso saber perder-se de vez em quando"362 para não se perder completamente, para não adoecer completamente na presunção de si.

Tomadas conjuntamente [Humano, demasiado Humano, Opiniões e Sentenças, O andarilho e sua sombra], talvez transmitam de modo mais nítido e forte seu ensinamento - uma doutrina da saúde (...). Nelas fala um pessimista que frequentemente ficou exasperado, fora de si, mas sempre voltou a si, um pessimista, portanto, com boa vontade em relação ao pessimismo. ${ }^{363}$

Nesse sentido, procurando uma concepção filosófica que não se desenvolvesse mediante o sentimento de culpa, de autodesprezo, porém mediante a afirmação de si mesmo, Nietzsche antecipa em Humano, demasiado Humano o que irá desenvolver no fim da segunda dissertação da Genealogia da Moral, onde aponta que a

\footnotetext{
356 NIETZSCHE, F., Opiniões e sentenças, §159, p. 73.

357 NIETZSCHE, F., Humano, demasiado humano, §473, p. 231.

358 Ibid. $\$ 120$, p. 90.

359 Ibid. $\$ 111$, p. 86.

360 Ibid. $\$ 128$, p. 92.

361 NIETZSCHE, F., Gaia ciência, prefácio , §3, p. 12.

362 NIETZSCHE, F., O andarilho e sua sombra, §306, p. 298.

363 NIETZSCHE, F., Humano, demasiado humano II, prefácio, §2, p 09.
} 
grande saúde consiste na tentativa de inverter o "olhar ruim" com que os homens tantas vezes enxergaram suas propensões naturais, seu grande nojo por si mesmo e o autodesprezo por trás de cada um dos seus ideais. A grande saúde como inversão do grande nojo. Mas para isso, para ser capaz de afirmar a si mesmo, isto é, para se poder ter um, digamos assim, um "olhar bom" com relação aos próprios instintos, com relação aos próprios impulsos, o perigo e a dor se tornam uma necessidade. E quem é forte para isso? ${ }^{364}$ Até chegar o momento de ser capaz de afirmar a si mesmo será preciso ainda saber esperar e ter força para poder suar...

Precisamente quem está vindo a ser não admite o vir-a-ser: é impaciente demais para isso. O jovem não quer esperar até que, após longos estudos, sofrimentos e privações, seu quadro das pessoas e das coisas esteja completo: então aceita (...) um outro que está pronto e lhe é oferecido, (...) ele se entrega a um filósofo, a um poeta, e durante muito tempo tem que labutar como servo e negar a si mesmo. Nisso, um jovem aprende muita coisa: mas frequentemente esquece o mais digno de aprendizado e conhecimento: esquece a si mesmo; pelo resto da vida continua a ser um partidário. Ah, é grande o tédio a vencer, é preciso muito suor, até alguém achar suas cores, seu pincel, sua tela! ${ }^{365}$

Afirmemos nossos instintos, nossos prazeres, nossa necessidade, nossa luta por prazer, mas nem por isso "devemos nos deixar tiranizar pelo mais belo prazer: o de elevar as coisas ao plano ideal; senão, um dia a verdade se afasta de nós com estas palavras feias: rematado mentiroso, que tenho eu a ver contigo?" ${ }^{366}$ Esse é o motivo de Nietzsche criticar o adoecimento da religião, da música moderna, da ciência moderna: por excesso de sentimento são demasiadamente complacentes com seus próprios desejos, o que os torna incapazes de organizar seus impulsos, de refreá-los, e assim acabam por presumir um poder, um prazer que não têm, acabam por fazer pontes em direção a mundos melhores, acabam elevando as coisas ao plano ideal e achando que assim estão a conquistar uma saúde, um prazer superlativo, a conquistar um fortalecimento, quando estão na verdade se debilitando cada vez mais, se enfraquecendo, se tornando cada vez mais negadores do que lhes opõe resistência, do que resiste à sua ânsia de poder - forte não é aquele que não encontra resistências e obstáculos para a sua força, que não vê limites para a sua expansão, mas aquele que "necessita de resistências, portanto busca resistência"367 — incapazes de responder às adversidades que a transitoriedade da vida exige sem que para isso seja preciso desistir da própria vida. Mas desistem da vida e criam mundos ideais. Porém, até quando os ideais poderão sobreviver às pressões da

\footnotetext{
364 NIETZSCHE, F., Genealogia da moral, II, §24, p. 84.

365 NIETZSCHE, F., O andarilho e sua sombra, §266, p. 278.

366 NIETZSCHE, F., Opiniões e sentenças, §345, p. 143.

367 NIETZSCHE, F., Ecce homo, Por que sou tão sábio, §7, p. 29.
} 
vida? "Onde vocês vêem coisas ideais, eu vejo - coisas humanas, ah, somente coisas demasiado humanas!" ${ }^{368}$ E o que pode um ideal sob a pressão da doença?

Que haja prazer, pois a vida necessita obter satisfações; não há vida se não houver prazer, "mas o perene querer-viver e não-poder-morrer já é um indício de senilidade de sentimento: quanto mais plena e vigorosamente alguém vive, tanto mais está disposto a dar a vida por uma só sensação boa" ${ }^{369} \mathrm{O}$ excesso de sentimento fez com que muitos artistas, filósofos e religiosos criassem mundos ideais e procedessem por convicções, isto é, pela crença de estarem de posse da verdade absoluta ${ }^{370}$; tal ódio ao limite e à medida é característico do espírito moderno ${ }^{371}$. Contra essa tendência excessiva que procede por convicção, que constrói mundos ideais onde tudo parece harmônico, onde tudo parece perene satisfação e ausência de dor, contra essa tendência Nietzsche irá propor uma filosofia da opulência, uma filosofia que tenha espírito científico, isto é, uma que seja capaz de "amadurecer no homem a virtude da cautelosa abstenção" ${ }^{372}$, e nesse limite ser capaz de conquistar uma abundância ${ }^{373}$, de cultivar uma opulência, uma saúde, uma que se orgulhe de poder ter vivido em circunstâncias caracterizadas por um "mínimo de vida"374, isto é, mínimo de prazer, mínimo de poder, e dessas condições poder ter extraído um fortalecimento espiritual, uma que não almeje a completa ausência de dor - como discursam os homem que se encontram doentes ${ }^{375}$ — pois já se vê capaz de desejar. Ao contrário dessa tendência que visa eliminar todo incômodo, toda condição desfavorável, todo limite, todas as fontes de desprazer ${ }^{376}$, "desejar é sinal de melhora ou convalescença"

"O filósofo da opulência." - Um pequeno jardim, figos, porções de queijo e três ou quatro bons amigos - esta foi a opulência de Epicuro. ${ }^{378}$

A derrocada da crença de estar de posse de verdades absolutas é imprescindível para que não se sinta nojo por si mesmo, nojo por toda ausência de certeza, nojo pelos instintos; tal derrocada é imprescindível para que se possa afirmar a si

\footnotetext{
368 NIETZSCHE, F., Ecce homo, Humano, demasiado humano, §1, p. 69.

369 NIETZSCHE, F., $O$ andarilho e sua sombra, §187, p. 248.

370 NIETZSCHE, F., Humano, demasiado humano, §630, p. 266.

371 Ibid. $\$ 221$, p. 138.

372 Ibid. $§ 631$, p. 267.

373 NIETZSCHE, F., O andarilho e sua sombra, §113, p. 218.

374 NIETZSCHE, F., Humano, demasiado humano II, prefácio, §5, p. 12.

375 NIETZSCHE, F., Opiniões e sentenças, §349, p. 144.

376 Ibid. $\$ 187$, p. 90.

377 Ibid. §349, p. 144.

378 NIETZSCHE, F., O andarilho e sua sombra, §192, p. 252.
} 
mesmo, para que se possa conquistar uma saúde, uma que não tenha nojo e desprezo por toda doença e que já não crê ser possível deter a posse de uma saúde absoluta, robusta. Saber que na vida não se pode proceder por convicções é saber que não há verdades absolutas, que não há a "coisa em si”, assim como não pode haver uma saúde em si $^{379}$ ou uma doença em si, sendo então preciso saber utilizar a maré ${ }^{380}$, os "contraditórios estados de indigência e felicidade na alma e no corpo"381, pois "com a liberdade de opiniões sucede o mesmo que à saúde: ambas são individuais, não se pode criar um conceito de validade geral para nenhuma delas." 382

A morte da verdade absoluta é condição para que a plenitude possa ser conjugada a uma certa ausência, ausência de certeza $^{383}$, para que o deserto possa se transformar num exuberante pomar; só assim pode-se escapar de uma ausência de si e retornar a si mesmo, só assim pode-se responder com saúde, pois o mais fundamental para a grande saúde não é saber se a vida é rica ou pobre, doce ou amarga, se tal indivíduo se encontra em condições favoráveis, com os seus órgão funcionando perfeitamente ou encontram-se parcialmente debilitados, pois apesar de a saúde e a doença designarem estados físicos, elas designam também, e sobretudo, estados espirituais, onde o que está em questão é a resposta, ou seja, não se trata mais de perguntar "o que é?", mas "o que se faz?"

"Grandeza significa: dar direção." — Nenhum rio é por si mesmo grande e abundante; é o fato de receber e levar adiante muitos afluentes que o torna assim. $\mathrm{O}$ mesmo sucede com todas as grandezas do espírito. Interessa apenas que um homem dê a direção que os muitos afluentes devem seguir; e não que ele inicialmente seja pobre ou rico em dons. ${ }^{384}$

O que se faz quando se está sob pressão da doença, sob pressão de estados físicos debilitados? Como responder a isso? Diante de tais situações, o que mais comumente se fez até hoje foi construir mundos ideais, mas essa seria para Nietzsche uma resposta doente, uma resposta que pretende extirpar as condições desfavoráveis que a vida por vezes nos impõe, mas que através dessa negação impede que nos tornemos saudáveis, isto é, que nos tornemos capazes de conquistar nossa saúde, de responder $^{385}$ à vida com saúde, sem precisar querer tornar as coisas fáceis demais para

\footnotetext{
379 NIETZSCHE, F., Gaia ciência, §120, p. 144.

380 NIETZSCHE, F., Humano, demasiado humano, §500, p. 241.

381 Ibid. prefácio, §7, p. 13.

382 Ibid. $\$ 286$, p. 177.

383 NIETZSCHE, F., O andarilho e sua sombra, §16, p. 173.

384 NIETZSCHE, F., Humano, demasiado humano, §521, p. 243.

385 NIETZSCHE, F., Humano, demasiado humano II, prefácio, §4, p. 11.
} 
nós, pois a dimensão incurável ${ }^{386}$ da vida não deve fazer com que a tomemos como uma objeção à vida, uma objeção a nossa própria cura, mas antes como um estímulo para esta, uma condição. A confiança na vida se foi, é verdade, mas ainda é possível amá-la, apenas se ama diferente, tal como se ama uma mulher a qual se duvida ${ }^{387}$.

"Morte" - Com a perspectiva certa da morte, uma deliciosa, odorosa gota de leviandade poderia ser mesclada a cada vida - mas vocês, estranhas almas de farmacêutico, dela fizeram uma gota de veneno de mau sabor, com que toda a vida se torna repugnante! ${ }^{388}$

386 NIETZSCHE, F., Opiniões e sentenças, §23, p. 23.

387 NIETZSCHE, F., Gaia ciência, prefácio, §3, p. 13.

388 NIETZSCHE, F., O andarilho e sua sombra, §322, p. 303. 


\section{Conclusão}

Meu problema nessa dissertação foi tentar entender não apenas como Nietzsche articula saúde e doença, mas como ele inclui na saúde a doença. Nesse sentido, o homem saudável não é aquele que não adoece (cotidianamente falamos que uma pessoa é forte quando ela não adoece), mas aquele que é capaz de adoecer; o homem saudável é aquele que tem potência para poder se permitir a doença, a dor, a desrazão, o involuntário, os estados debilitados, a inatividade, o feio, o horror, a impotência, a privação, a solidão, a abstinência, e o mais importante: ser capaz de tomar esses estados debilitados, essas condições desfavoráveis, como meio e estímulo para seu restabelecimento, para o retorno à uma saúde.

Esse é um ponto importante, a grande saúde não diz de uma incessante oscilação entre a doença e a saúde, pois tem seu centro de gravidade; o ponto de maior gravidade na grande saúde não é a oscilação incessante, nem a doença, mas a saúde, ou melhor, o retorno a uma saúde, a capacidade de superar a doença e retornar a uma saúde.

A dificuldade está em tomar a fraqueza como uma força e, procedendo assim, tomando a fraqueza como se fosse uma força, fazer recair na doença, na miséria e na pobreza o centro de gravidade da grande saúde. No entanto, Nietzsche não quer fazer uma filosofia da pobreza nem uma filosofia da doença; muito pelo contrário, Nietzsche quer uma filosofia da opulência, uma filosofia da saúde. E por que então ir à doença para pensar a saúde? Procedendo assim, indo à doença para pensar a saúde, chegando mesmo a incluir aquela nesta, Nietzsche não estaria sendo pessimista? Não estaria procedendo como um homem cansado, impotente, niilista? Se se quer uma filosofia da saúde, da plenitude, por que não dispensar a doença, a dor?

E no que toca à doença: não estaríamos quase tentados a perguntar se ela é realmente dispensável para nós? Apenas a grande dor é o extremo liberador do espírito, enquanto mestre da 'grande suspeita' (...). Apenas a grande dor, a lenta e prolongada dor, aquela que não tem pressa, na qual somos queimados com madeira verde, por assim dizer, obriga a nós, filósofos, a alcançar nossa profundidade extrema e nos desvencilhar de toda confiança, toda benevolência, tudo o que encobre, que é brando, mediano, tudo em que antes púnhamos nossa humanidade. Duvido que uma tal dor "aperfeiçoe" —; mas sei que nos 'aprofunda'. ${ }^{389}$

389 NIETZSCHE, F., Gaia Ciência, §3, prefácio, p. 13. 
Por que uma grande dor seria tão crucial para uma filosofia da saúde, da riqueza e da opulência? Como grande dor pode rimar com plenitude? Nietzsche não estaria desse modo partindo da fraqueza para pensar a força? Partindo da doença para pensar a saúde? Mas seria possível o contrário, pensar a doença, isto é, os estados debilitados, a perda de si, o jazer na cama solitário, a privação de amigos, a privação da capacidade de andar, de ler, de ver, de dormir... seria possível pensar esses estados como decorrência de uma força, e não de uma fraqueza, de uma saúde e não de uma doença, de uma plenitude e não de uma privação? Essa é a pergunta que Nietzsche se coloca no primeiro parágrafo da sua Tentativa de autocrítica feita em $O$ nascimento da tragédia:

Será o pessimismo "necessariamente" o signo do declínio, da ruína, do fracasso, dos instintos cansados e debilitados (...)? Há um pessimismo da "fortitude"? Uma propensão intelectual para o duro, o horrendo, o mal, o problemático da existência, devido ao bem-estar, a uma transbordante saúde, a uma "plenitude" da existência? Há talvez um sofrimento devido à própria superabundância? ${ }^{390}$

Para tentar pensar isso, parti de duas indicações de Nietzsche: uma feita em Ecce homo, onde Nietzsche diz que foi durante seus anos de menor vitalidade, período de $O$ andarilho e sua sombra, que ele deixou de ser pessimista; a outra indicação está no prefácio ao segundo volume de Humano Demasiado Humano, onde Nietzsche diz que o maior ensinamento desta obra consiste numa doutrina da saúde. Mas, embora o veio principal dessa dissertação tenha estado sobretudo numa leitura de Humano demasiado humano, em alguns momentos recorri a outras obras. Por exemplo, no segundo capítulo, "Grandeza, música, saúde e direção: uma crítica à intuição intelectual por Nietzsche", fui a $O$ caso Wagner e Nietzsche contra Wagner, onde mostro que Nietzsche aponta Wagner como sendo o caso clínico mais revelador da modernidade, pois nele se pode ver como age a "duplicidade dos instintos", "o duplo sentido", artifício que quer nos fazer crer que afirmando uma arte do grandioso (as orquestrações gigantescas, as melodias infinitas, onde tudo no fim parece se salvar) está se afirmando uma grande arte, e com esse artifício causa-se a impressão que está-se dizendo sim à vida quando na verdade está-se negando-a, está-se rejeitando todo limite, toda dor, ao invés de tomá-la como estímulo; segundo Nietzsche, Wagner assim cria mundos ideais travestidos de uma saúde robusta, mas o que subjaz a esse ideal não é senão doença, vontade de negação da vida, vontade que cria mundos ideais porque não é capaz de afirmar a vida nas suas oscilações entre os estados de indigência e abundância.

Se a vida não quer nunca se congelar, se fixar num único estado, Wagner a congela, a congela num estado "grandioso" por meio de sua música e assim, via o

390 NIETZSCHE, F., O nascimento da tragédia, prefácio, §1, p. 14. 
"grandioso", pretende dar cabo ao que seria sua obsessão pelo tema da salvação; no grandioso estaria a promessa da felicidade, promessa de que dando livre curso aos nossos impulsos obteríamos a felicidade e a plena satisfação. No entanto, grandeza e grandioso são termos distintos na ótica nietzscheana; na vida, estando tudo em vir a ser, não há condições que possibilitem a existência de um estado "grandioso em si", de uma coisa-em-si, assim como não há uma "saúde em si" ou mesmo uma "doença em si". Mas isso não impede que possa haver grandeza nas ações. Para Nietzsche, grandeza é dar direção, é um operar seletivamente, e onde está em jogo não o quanto se é rico ou pobre em dons, mas o que se faz com cada dom, a direção que lhes é dada, a condução que é dada aos impulsos. Nesse sentido, a grande saúde não é uma saúde grandiosa, robusta, perene, absoluta, mas uma saúde que se reflete na capacidade de direcionar os instintos, de retê-los, hierarquizá-los, conduzi-los, ainda que nos encontremos em condições debilitadas, em condições desfavoráveis, doentes, e nossos instintos tenham de esperar, aguardar mais prolongadamente para poder satisfazer-se.

No terceiro capítulo, "Música e o problema da saúde", fui à República de Patão para mostrar como este filósofo já estava ocupado com a questão da saúde; porém, ao contrário de Nietzsche, Platão pensava a saúde por uma relação de identidade, isto é, para Platão a saúde só é saúde enquanto se conserva inalterada e exclui toda doença. Para Platão a verdadeira saúde é a que pouco se altera; e nesse sentido a música, ou melhor, a "boa música" no seu entender, pode ser um ótimo "remédio" desde que harmonizada e construída com a finalidade de ser um estímulo auxiliar na conservação e no repouso da saúde nela mesma, isto é, na manutenção de uma saúde em si.

No último capítulo, "Da vontade de prazer", procurei mostrar que a posição de Nietzsche em Humano demasiado humano é de que a vida é luta por prazer ou poder, pois, nesse momento de sua obra, poder é prazer, e vice-versa. Mas, se é da natureza do sistema nervoso se proteger contra a dor, por que Nietzsche critica o fato da ciência moderna e da religião terem por meta o mínimo de dor possível? Querer o prazer não é, para Nietzsche, um erro, mas sim o excesso de sentimento. Que haja prazer! pois na vida a satisfação é uma necessidade; a vida não se sustenta se não houver prazer algum, mas o perene querer-viver, querer a vitalidade a qualquer preço, querer a qualquer custo não-poder-morrer já indício de uma senilidade de sentimento. Contra essa tendência, contra esse ódio ao limite e à medida, ódio tão presente na modernidade, Nietzsche propõe uma filosofia da opulência, isto é, uma que seja capaz de amadurecer no homem a virtude da cautelosa abstenção e de sob esse limite ser capaz de conquistar uma abundância, um excesso de forças plásticas, uma saúde, uma que se orgulhe de poder ter vivido em circunstâncias caracterizadas por um mínimo de vida e dessas condições ter saído mais fortalecida. 
Ao invés de eliminar todo incômodo, toda doença, toda condição desfavorável, toda limitação, toda dor, desejar já é sinal de saúde ${ }^{391}$, tanto quanto a saúde muitas vezes não está na vitória, mas no querer vencer, uma vitória que virá, tem de vir, talvez já tenha vindo ${ }^{392}$.

391 NIETZSCHE. Opiniões e Sentenças, §349, p. 144.

392 NIETZSCHE, F. Humano, demasiado humano, prefácio, §3, p. 10. 


\section{Referências Bibliográficas}

ANDLER, Charles. Nietzsche, sa vie et sa pensée. Paris: Gallimard, 1958.

ANDRÉAS-SALOMÉ, Lou. Fréderic Nietzsche. Paris: Grasset, 1932.

BARRENECHEA, Miguel. Nietzsche: a memória, o esquecimento e a alegria da superfície. In: Nietzsche e os gregos: arte, memória e educação: Assim falou Nietzsche V. Rio de Janeiro: DP \&A, 2006.

. Nietzsche e o corpo. Rio de Janeiro: 7 Letras, 2010.

BRUMM, Thomaz. O pessimismo e suas vontades: Schopenhauer e Nietzsche. Rio de Janeiro: Rocco, 1998.

CHERLONNEIX, Laurent. Nietzsche: santé et maladie, l'art. Paris: L'Harmattan, 2002.

COLLI, Giorgio. Après Nietzsche. Paris: Editions de l'Eclat, 1987.

Ecrits sur Nietzsche. Paris: Eclat, 1998.

DELEUZE, Gilles. "Da comunicação dos acontecimentos". In: A Lógica do Sentido. São Paulo: Ed. Perspectiva, 2006.

Nietzsche et la philosophie. Paris: PUF, 2003.

Nietzsche. Paris: PUF, 1965.

DIAS, Rosa Maria. Nietzsche e a música. Rio de Janeiro: Imago, 1994. 2011 .

. Nietzsche, vida como obra de arte. Rio de Janeiro: Civilização Brasileira,

FERRAZ, Maria Cristina Franco. Nietzsche, o bufão dos deuses. Rio de Janeiro: Relume Dumará, 1994.

FINK, Eugen. Nietzsche. La philosophie de Nietzsche. Paris: Minuit, 1965.

FONTAINE, Jean-Michel. Le vocabulaire latin de la philosophie. Paris: Ellipses, 2005.

FOUCAULT, Michel. Nietzsche, Freud e Marx. In: Nietzsche, Cahiers de Royaumont, Paris: Minuit, 1967.

GRANIER, Jean. Le problème de la vérité dans la philosophie de Nietzsche. Paris: Éditions du Seuil, 1966.

GIACÓIA, Oswaldo. Nietzsche como psicólogo. São Leopoldo, RS: Ed. Unisinos, 2001.

HAAR, Michel. Nietzsche et la métaphysique. Paris: Gallimard, 1993.

HEIDEGGER, Martin. Nietzsche. Vol. I e II. Paris: Gallimard, 1971.

KELLER, Alfred. Michaelis: dicionário escolar alemão. São Paulo: Ed. Melhoramentos, 2009.

KLOSSOWSKI, Pierre. Nietzsche et le cercle vicieux.Paris: Mercure de France, 1969.

Un Si Funeste Désir. Paris: Gallimard, 1963. 
MACEDO, Iracema. Nietzsche, Wagner e a Época trágica dos gregos. São Paulo : Annablume, 2006.

MACHADO, Roberto. Nietzsche e a Verdade, Rio de Janeiro, Graal, 1999.

Deus, homem, super-homem. Revista Kriterion, n.89, Belo Horizonte, UFMG, 1994.

. Zaratustra, tragédia nietzscheana. Rio de Janeiro: Jorge Zahar,1997.

MARTON, Scarlett. Das forças cósmicas aos valores humanos. Belo Horizonte: Ed. UFMG, 2000.

MAURANO, Denise. La face cachée de l'amour: une investigation philosophique de la tragédie à la lumière de la psychanalyse. FR: Presses Universitaires deSeptentrion, 1999.

MÜLLER-LAUTER, Wolfgang. A Doutrina da Vontade de Poder em Nietzsche. São Paulo: Annablume ed., 1997.

MURICY, Kátia. A arte do estilo. In: Assim Falou Nietzsche III, org. Barrenechea, Miguel Angel. Rio de Janeiro: 7Letras, 2001.

NIETZSCHE, Friedrich. Werke Kritiche Gesamtausgabe. Edição crítica organizada por G. Colli e M. Montinari, Berlim, Walter de Gruyter \& Co, 1967/1978, 30 V: Ed. Fr. Paris, Gallimard, 1977.

. Cahiers de Royaumont. Paris: Minuit, 1967.

. Assim falava Zaratustra. Rio de Janeiro: Civilização Brasileira. 2008.

. Aurore. Fragments Posthumes. Tome IV, début 1880/printemps1881.

Paris, Gallimard, 1978.

. Considérations inactuelles II. Paris: Gallimard, 1992.

. Crepúsculo dos ídolos. São Paulo: Companhia das letras. 2006.

Ecce homo. São Paulo: Companhia das Letras. 2008.

Gaia ciência. São Paulo: Companhia das Letras. 2009.

Genealogia da moral . São Paulo: Companhia das Letras. 2004.

. Humano, demasiado humano I e II. São Paulo: Companhia das Letras.

2000.

Le cas Wagner. Paris: Gallimard. 1974.

Nietzsche contre Wagner. Paris: Éditions Gallimard. 1974.

O nascimento da tragédia. São Paulo: Companhia das Letras, 1992.

ONATE, Alberto Marcos. O crepúsculo do sujeito em Nietzsche. São Paulo: Discurso Editorial/Editora Unijuí, 2000.

Entre eu e si ou a questão do humano na filosofia de Nietzsche. vol.1.

Rio de Janeiro: 7Letras, 2003.

Nietzsche e o caos: a abordagem de Michel Haar. In: Cadernos

Nietzsche, n.5, São Paulo, USP, 1998.

PLATÃO. A República: ou sobre a justiça. São Paulo: Martins Fontes, 2006.

Hípias Menor: sobre a mentira. Porto Alegre, RS: Ed. LP \&M, 2008.

RAYMOND, Didier. Nietzsche ou la grande santé. Paris: L'Harmattan, 1999. 
ROSSET, Clément. La force majeure. Paris: Ed. Minuit, 1983.

ROCHA, Sílvia Pimenta Velloso. Os abismos da suspeita - Nietzsche e o perspectivismo. Rio de Janeiro: Relume Dumará, 2003.

O niilismo é algo que não se cura - notas sobre a grande saúde. In: Nietzsche e as ciências, org. Miguel Barrenechea, Charles Feitosa, Paulo Pinheiro, Rosa Suarez. Rio de Janeiro: 7Letras, 2011.

SONTAG, Susan. Doença como metáfora. São Paulo: Companhia das Letras, 2007.

VATTIMO, Gianni. Introdução a Nietzsche. Tradução de Antônio Gerreiro. Lisboa: Editorial Presença, 1990.

VIEIRA, Cristina Amorim. O desafio da grande saúde em Nietzsche. Rio de Janeiro: 7letras, 2000. 